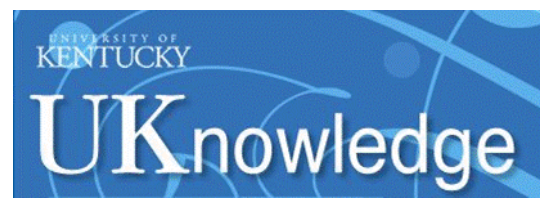

University of Kentucky

UKnowledge

\title{
ZIRCON AS A PROXY FOR "TAKING THE TEMPERATURE" OF GRANITES: AN EXAMPLE USING ZIRCON THERMOMETRY APPLIED TO GRENVILLIAN MID-CRUSTAL MAGMAS IN THE BLUE RIDGE PROVINCE, VIRGINIA
}

Samantha Rae Burk

University of Kentucky, sbu249@uky.edu

Digital Object Identifier: https://doi.org/10.13023/ETD.2017.118

Right click to open a feedback form in a new tab to let us know how this document benefits you.

\section{Recommended Citation}

Burk, Samantha Rae, "ZIRCON AS A PROXY FOR "TAKING THE TEMPERATURE" OF GRANITES: AN EXAMPLE USING ZIRCON THERMOMETRY APPLIED TO GRENVILLIAN MID-CRUSTAL MAGMAS IN THE BLUE RIDGE PROVINCE, VIRGINIA" (2017). Theses and Dissertations--Earth and Environmental Sciences. 46.

https://uknowledge.uky.edu/ees_etds/46

This Master's Thesis is brought to you for free and open access by the Earth and Environmental Sciences at UKnowledge. It has been accepted for inclusion in Theses and Dissertations--Earth and Environmental Sciences by an authorized administrator of UKnowledge. For more information, please contact UKnowledge@lsv.uky.edu. 


\section{STUDENT AGREEMENT:}

I represent that my thesis or dissertation and abstract are my original work. Proper attribution has been given to all outside sources. I understand that I am solely responsible for obtaining any needed copyright permissions. I have obtained needed written permission statement(s) from the owner(s) of each third-party copyrighted matter to be included in my work, allowing electronic distribution (if such use is not permitted by the fair use doctrine) which will be submitted to UKnowledge as Additional File.

I hereby grant to The University of Kentucky and its agents the irrevocable, non-exclusive, and royalty-free license to archive and make accessible my work in whole or in part in all forms of media, now or hereafter known. I agree that the document mentioned above may be made available immediately for worldwide access unless an embargo applies.

I retain all other ownership rights to the copyright of my work. I also retain the right to use in future works (such as articles or books) all or part of my work. I understand that I am free to register the copyright to my work.

\section{REVIEW, APPROVAL AND ACCEPTANCE}

The document mentioned above has been reviewed and accepted by the student's advisor, on behalf of the advisory committee, and by the Director of Graduate Studies (DGS), on behalf of the program; we verify that this is the final, approved version of the student's thesis including all changes required by the advisory committee. The undersigned agree to abide by the statements above.

Samantha Rae Burk, Student

Dr. David P. Moecher, Major Professor Dr. Edward W. Woolery, Director of Graduate Studies 
ZIRCON AS A PROXY FOR “TAKING THE TEMPERATURE” OF GRANITES: AN EXAMPLE USING ZIRCON THERMOMETRY APPLIED TO GRENVILLIAN MIDCRUSTAL MAGMAS IN THE BLUE RIDGE PROVINCE, VIRGINIA

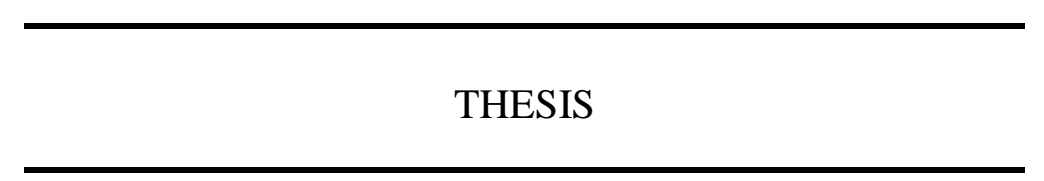

A thesis submitted in partial fulfillment of the requirements for the degree of Master of Science in the College of Arts and Sciences at the University of Kentucky

By

Samantha Rae Burk

Lexington, Kentucky

Director: Dr. David P. Moecher, Professor of Geology

Lexington, Kentucky

2017

Copyright ${ }^{\circledR}$ Samantha Rae Burk 2017 


\section{ABSTRACT OF THESIS}

\section{ZIRCON AS A PROXY FOR “TAKING THE TEMPERATURE” OF GRANITES: AN EXAMPLE USING ZIRCON THERMOMETRY APPLIED TO GRENVILLIAN MID- CRUSTAL MAGMAS IN THE BLUE RIDGE PROVINCE, VIRGINIA}

The Grenville orogeny was a protracted ( 200 m.y.) series of "hot" magmaticmetamorphic events that contributed to the growth of the Laurentian margin in the late Mesoproterozoic. The granites contain remarkably high Zr content, lack xenocrysts, and become zircon saturated at high temperatures, which are all unusual for felsic magmas. The "hot Grenville granite" hypothesis is tested and use of high-Zr granitoids as potential zones of crustal magma generation through: U-Pb geochronology and cathodoluminescence imaging to assess inherited zircon components; quantitative modeling of zircon crystallization history using rhyolite-MELTS; and Ti-in-zircon thermometry. U-Pb zircon ages for two samples from the Virginia Blue Ridge are $1168 \pm$ $25 \mathrm{Ma}\left(2209 \mathrm{ppm} \mathrm{Zr;} \mathrm{T}_{\mathrm{zr}}=1032^{\circ} \mathrm{C}\right)$ and $1050 \pm 13 \mathrm{Ma}\left(918 \mathrm{ppm} \mathrm{Zr} ; \mathrm{T}_{\mathrm{zr}}=898^{\circ} \mathrm{C}\right) . \mathrm{A}$ sample from the NJ - Hudson Highlands has been dated at $1018 \pm 11$ Ma (1238 ppm Zr; $\left.\mathrm{T}_{\mathrm{zr}}=960^{\circ} \mathrm{C}\right)$. These samples produce crystallization histories that range over higher temperatures $\left(983-1060^{\circ} \mathrm{C}\right)$ than colder, low-Zr counterparts and contain $\mathrm{Ti}$ concentrations of 2 to $86 \mathrm{ppm}$. This analytical approach will further the understanding of zircon's utility and limitations as a proxy in granite petrogenesis, and constrain thermal models that produced uncommon lithospheric conditions that led to widespread hot granite production at a unique period in Earth history.

KEYWORDS: Blue Ridge Province, Grenville Basement, Ti-in-zircon, Geothermometry, Zircon Saturation

Samantha R. Burk

April 26, 2017 
ZIRCON AS A PROXY FOR “TAKING THE TEMPERATURE” OF GRANITES: AN EXAMPLE USING ZIRCON THERMOMETRY APPLIED TO GRENVILLIAN MIDCRUSTAL MAGMAS IN THE BLUE RIDGE PROVINCE, VIRGINIA

By

Samantha Rae Burk

\begin{tabular}{c} 
David P. Moecher \\
\hline Director of Thesis \\
Edward W. Woolery \\
\hline Director of Graduate Studies \\
April 26, 2017 \\
\hline
\end{tabular}




\section{ACKNOWLEDGEMENTS}

Firstly, I would like to thank my advisor Dr. Dave Moecher for providing the direction, geologic expertise, and support for this thesis. I have greatly benefitted from his mentorship and guidance throughout my time in the department, and truly feel that I have grown not only as a geologist but as a scientist in general. I would like to thank additional committee members Dr. Ryan Thigpen and Dr. Sean Bemis for their comments and criticisms, as well as Dr. Scott Samson of Syracuse University for helpful insights.

Without funding from NSF grant EAR 1447605 this project would not have been possible. The Earth and Environmental Science department here at the University of Kentucky funded my travel to conduct research and present at a conference through the Ferm and Brown-McFarlan Funds. I appreciate the assistance I received from those at Washington State University’s GeoAnalytical Lab, UCLA’s Keck Microprobe Lab, Stanford University’s SHRIMP-RG lab, and Jason Backus at the Kentucky Geological Survey’s XRF facilities.

Lastly, I would like to thank my family and loved ones for encouraging me on a daily basis through thesis writing and preparation. I am incredibly grateful to my friends for laughing at my terrible puns and helping me see the light at the end of the graduate school tunnel. 


\section{TABLE OF CONTENTS}

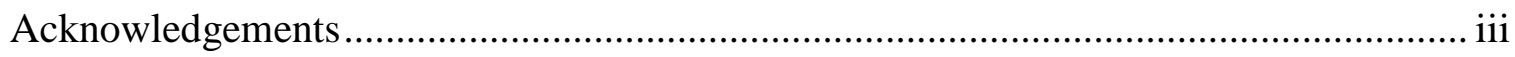

Table of Contents ................................................................................................... iv

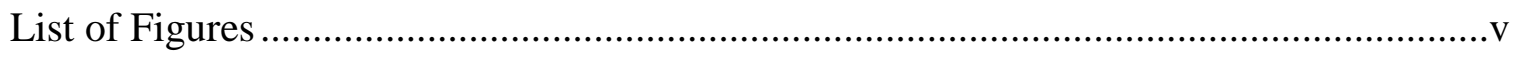

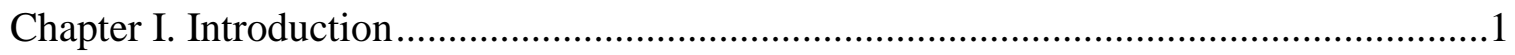

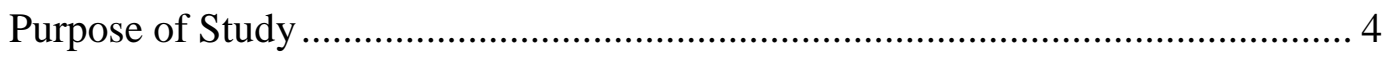

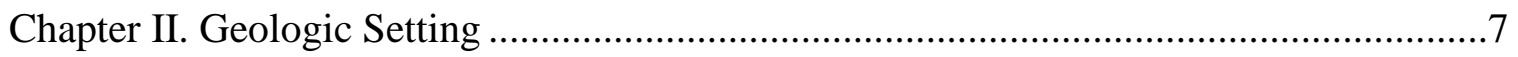

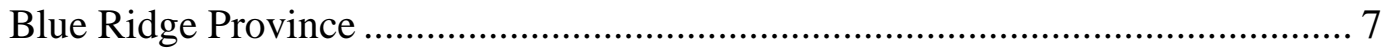

New Jersey - Hudson Highlands ............................................................. 8

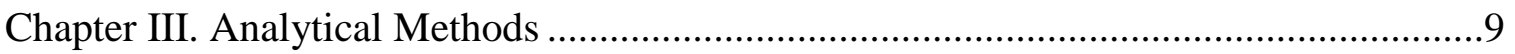

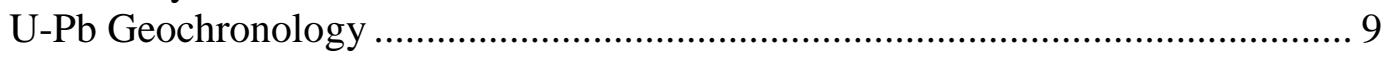

Whole Rock Geochemistry: X-ray Fluorescence ........................................... 11

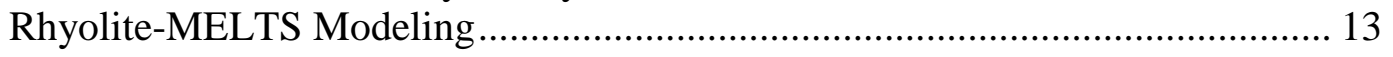

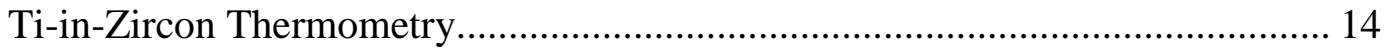

Chapter IV. Sample Descriptions and Petrology ......................................................15

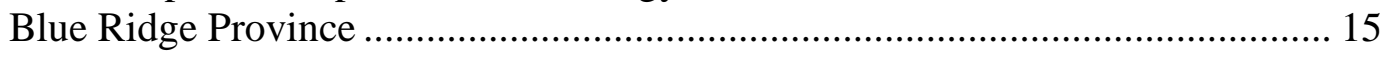

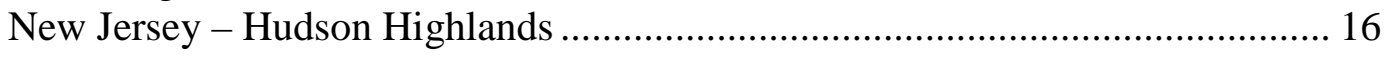

Chapter V. Results of U-Pb Geochronology............................................................20

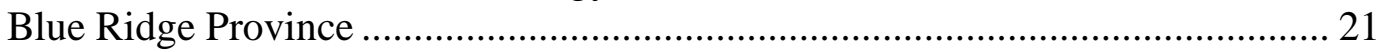

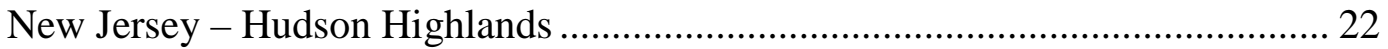

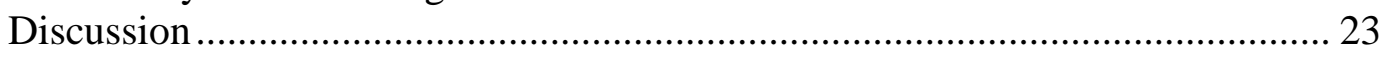

Chapter VI. Results of Crystallization Modeling .......................................................36

Blue Ridge Province ................................................................................. 37

New Jersey - Hudson Highlands ................................................................. 38

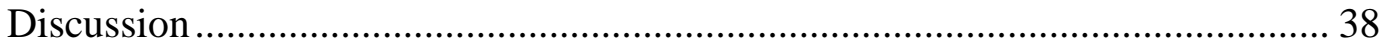

Chapter VII. Results of Ti-in-zircon Thermometry …..............................................42

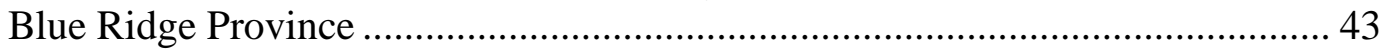

New Jersey - Hudson Highlands ................................................................ 43

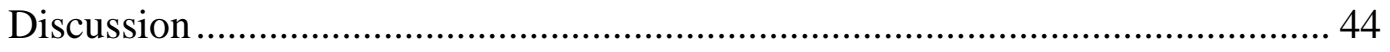

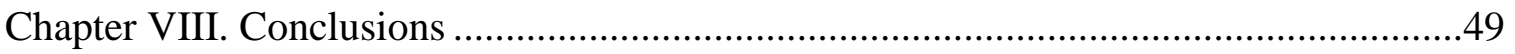

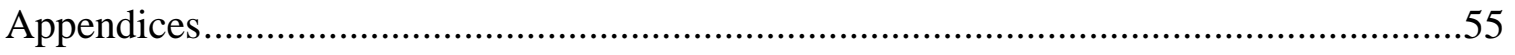

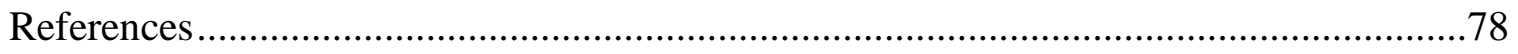

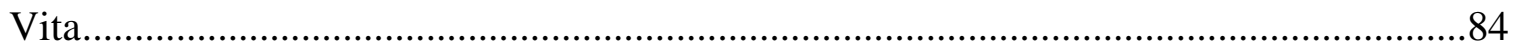




\section{LIST OF FIGURES}

Figure 1.1: Generalized map displaying locations of exposed Grenville-aged rocks in the

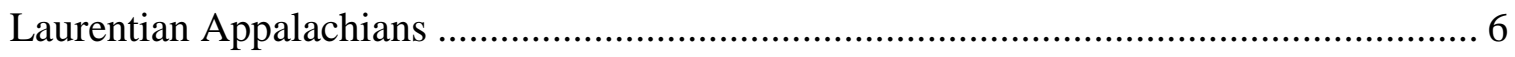

Figure 4.1a: Photomicrograph of VA 15-1 in plane-polarized light............................. 17

Figure 4.1b: Photomicrograph of VA 15-1 in cross-polarized light ............................ 17

Figure 4.2a: Photomicrograph of VA 15-2 in plane-polarized light.............................. 18

Figure 4.2b: Photomicrograph of VA 15-2 in cross-polarized light .............................. 18

Figure 4.3a: Photomicrograph of NJ 15-1 in plane-polarized light .............................. 19

Figure 4.3b: Photomicrograph of NJ 15-1in cross-polarized light ................................ 19

Figure 5.1: Results of SIMS analysis of AS3 zircon standard from sample VA 15-1 „.... 25

Figure 5.2: Results of SIMS analysis of AS3 zircon standard from sample VA 15-2 ..... 26

Figure 5.3: Results of SIMS analysis of AS3 zircon standard from sample NJ 15-1...... 27

Figure 5.4: Pb-corrected results of SIMS analysis of grains from sample NJ 15-1........ 28

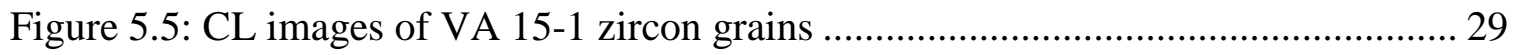

Figure 5.6: Results of SIMS analysis of zircon grains from sample VA 15-1 „.............. 30

Figure 5.7: CL images of VA 15-2 zircon grains .................................................... 31

Figure 5.8: Results of SIMS analysis of zircon grains from sample VA 15-2 …............ 32

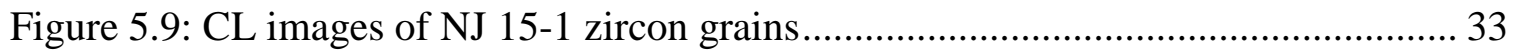

Figure 5.10a: Results of SIMS analysis of zircon grains from sample NJ 15-1 ............. 34

Figure 5.10b: Results of LA-ICP-MS analysis of zircon grains from sample NJ 15-1 .... 35

Figure 6.1: Sequence of melt crystallization output from rhyolite-MELTS at bulk-rock

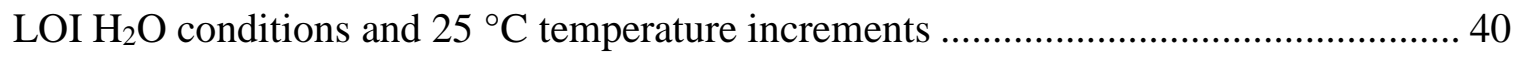

Figure 6.2: Results of crystallization modeling from rhyolite-MELTS ........................ 41 
Figure 7.1: Histogram of Ti-in-zircon concentration for all analyzed spots.................... 46

Figure 7.2: SEM images of selected SHRIMP-RG analysis spots .............................. 47

Figure 7.3: REE plot normalized to CI chondrite (McDonough and Sun, 1995) ............ 48

Figure 8.1: Estimated whole-rock zircon saturation temperatures $\left(\mathrm{T}_{\mathrm{zr}}\right)$ calculated using

the Watson and Harrison (1983) thermometer............................................................ 54 


\section{CHAPTER I. INTRODUCTION}

Zircon $\left(\mathrm{ZrSiO}_{4}\right)$, a widely used $\mathrm{U}-\mathrm{Pb}$ geochronometer, is also commonly used as a geothermometer in studies of crustal petrogenesis to determine temperatures of magmatic systems and high-grade metamorphism. Both total zirconium (Zr) concentration of a granitic magma and titanium (Ti) concentration of zircon crystallized from that magma are used to calculate crystallization temperatures. Watson and Harrison (1983) demonstrated experimentally that the solubility of $\mathrm{Zr}$ in a range of melt compositions is the key factor in the dissolution of zircon during melting in the source region of magmas. They also calibrated the $\mathrm{Zr}$ solubility as a function of temperature and magma composition, potentially allowing for determination of the temperature in the source region. The Ti concentration of zircon is also highly dependent on melt composition and temperature while being weakly dependent on pressure (Watson and Harrison, 2005), permitting calculation of zircon crystallization temperature, and by extension the temperature of the melt.

Recent work has revealed that there are only a few circumstances where zircon begins crystallizing near liquidus temperatures in granitic magmas. More commonly, zircon forms over a range of temperatures during the crystallization sequence in granites (100 - $200^{\circ} \mathrm{C}$; Harrison et al., 2007) and often closer to the solidus. Moecher et al. (2014) demonstrated by modeling of the crystallization sequence of modal silicates and zircon in two granitic magmas with high $\mathrm{Zr}$ content (830 and $1201 \mathrm{ppm}$ ) that zircon begins to crystallize near the liquidus in high $\mathrm{Zr}$ granites (approximately $1000^{\circ} \mathrm{C}$ ). In that same study, the crystallization temperature for granites with more typical Zr contents (100 $300 \mathrm{ppm}$ ) of crustal granites was nearly $200-300{ }^{\circ} \mathrm{C}$ lower than the liquidus. 
Watson and Harrison’s (1983) whole-rock zircon saturation thermometer $\left({ }^{2 r c} \mathrm{~T}_{\mathrm{sat}}\right)$ has pitfalls in its application as well. In their calibration, the calculated zircon saturation temperature doesn’t necessarily correspond to the initial temperature of zircon crystallization; it is the temperature at which zircon saturation of the melt occurred, which could be reached at any time and temperature during the crystallization between the liquidus and solidus.

Watson and Harrison's (1983) previous work eventually led to the suggestion of "hot” and “cold” granites (Miller et al., 2003). A "hot" granite is one that has a $\mathrm{T}_{\mathrm{Zr}}$ of 800 ${ }^{\circ} \mathrm{C}$ or more, generally lacks zircon xenocrysts inherited from the magma source region (because the melt temperature was high enough to dissolve potential xenocrysts), and is consistent with the fractionation of mantle-derived magma (Miller et al., 2003). "Cold” granitic magmas will likely contain zircon xenocrysts because melt temperature is too low $\left(<\sim 700^{\circ} \mathrm{C}\right)$ to dissolve inherited zircons, they are generated where crustal thickening occurs, and are present in systems where water can be included in the melt. Both granites may contain zircons with xenocrystic cores, but it is more likely that a high-temperature granite will have complete dissolution of zircon grains under conditions of magma generation. Magmatic conditions will also be more efficient in precipitating new zircons in hot granites because the $\mathrm{Zr}$ content of the melt will be high (Moecher and Samson, 2006).

Given these results, zircon chemistry and age do not necessarily yield a correlative temperature and time of crystallization of a magma, as inferred by U-Pb zircon geochronology corresponding to the onset of granite crystallization (i.e., liquidus temperatures). This notion has been explored in young, shallow felsic volcanic systems 
where zircon rims were enriched in $\mathrm{Ti}$, presumed to indicate higher temperatures during a later crystallization phase (Pamukcu et al., 2013). This discrepancy has yet to be fully resolved when examining granites originating from middle-to-lower crustal magmatic systems. Further examination of the use of zircon as a geothermometer is required to expand on the initial hot granite research as outlined in Moecher, et al., (2014). In that study, they hypothesized that the Grenville orogeny was an exceptionally hot series of collisional events, with prolonged and/or repeated waves of contributing magmatism (Rivers, 2008, 2009; Rino et al., 2008; Beaumont et al., 2010; Moecher et al., 2014). However, any geologically significant model of these magmatic conditions requires thermal constraints from crystals within rocks from the high-temperature settings. Grenvillian granites typically are Zr-rich, lack inherited zircon constituents (implying hotter magma source region), and have high modeled saturation temperatures, suggesting that these are truly hot granites (Moecher et al., 2014).

This thesis will evaluate the use of zirconium and zircon as a granite geothermometer in Grenvillian mid-crustal magmas from the central Blue Ridge of the Virginian Appalachians as well as the more northerly section in New York (Figure 1.1; Tollo et al., 2004a). More in-depth investigation will help to significantly expand our understanding on the limitations of zircon use for petrogenetic studies, especially for magmas emplaced in the middle to deep crust, and how to better interpret zircon saturation and Ti-in-zircon geothermometry. 


\section{Purpose of Study}

Calculating geologically meaningful temperatures for felsic magmatic systems is a challenging task. The original study by Watson and Harrison (1983) for constraining magmatic temperatures using zircon has been evaluated more critically in subsequent research (Harrison et al., 2007; Fu et al., 2008, Moecher et al., 2014) to further understand the limitations of zircon thermometry in magmatic systems. Dry, high-Zr granites $(1000+$ ppm) will crystallize zircon near the liquidus, though moderate-Zr $(\sim 320$ ppm) rocks will crystallize zircon at approximately $150{ }^{\circ} \mathrm{C}$ below liquidus conditions (Moecher et al., 2014). Following this trend, low-Zr ( 150 ppm) rocks become zircon saturated at $\sim 275{ }^{\circ} \mathrm{C}$ below the liquidus (Miller et al., 2003). This variability in ${ }^{\text {zrc }} \mathrm{T}_{\text {sat }}$ suggests that zircon $\mathrm{U}-\mathrm{Pb}$ ages and trace element compositions in plutonic systems do not reflect an instant in time, and rarely reflect initial thermal conditions of felsic melts. This thesis will test the hypothesis that various zircon crystallization geothermometers in ultrahigh to lower zirconium granites demonstrate how zircon crystallizes at near-liquidus and at near-solidus temperatures, respectively. For high-Zr granites, zircon saturation will occur sooner in the crystallization history and vice versa for lower-Zr granites. If correct, the ${ }^{\text {zrc }} \mathrm{T}_{\text {sat }}$ thermometer should be in better agreement with the Ti-in-zircon thermometer, and with the modeled onset of zircon crystallization, in high-Zr granites than low-Zr granites.

The first task of this study was to determine if the Grenvillian granites are indeed "hot” granites, by evaluating the presence or absence of an inherited xenocrystic component via cathodoluminescence (CL) imaging of zircon from high-Zr granitoids. The exceptionally high Zr contents of Grenville magmatic rocks in eastern Laurentia 
resulted in anomalously high zircon fertility (observed as both relatively high abundance and size of zircons) that introduced an age bias into the detrital zircon record of Neoproterozoic to modern clastic sedimentary systems across much of Laurentia (Moecher and Samson, 2006). Grenville granites with high Zr concentrations produced an abundance of zircon grains with ages at approximately 1.05 and $1.15 \mathrm{Ga}$ and consequently led to other crustal age components (e.g., those of the Taconian, Acadian, and Alleghanian orogenies) being obscured in the detrital zircon record.

The second task of this study, zircon U-Pb geochronology, will expand previous data for geochronologic age distributions in hot granites for the Grenville basement inliers of the Blue Ridge and New Jersey - Hudson Highlands. This project will also build upon the preliminary results found in the pilot study done by Moecher et al., (2014), where magmatic temperatures and crystallization sequences of granitoids with varying $\mathrm{Zr}$ content were numerically modeled using rhyolite-MELTS software (Gualda et al., 2012). In that study, Ti-in-zircon thermometry was compared with ${ }^{\text {zrc }} \mathrm{T}_{\text {sat }}$ thermometry (determined from whole rock major and trace element analysis), and the latter temperature was compared with those obtained from zircon crystallization spectra determined from rhyolite-MELTS modeling (Gualda et al., 2012). 


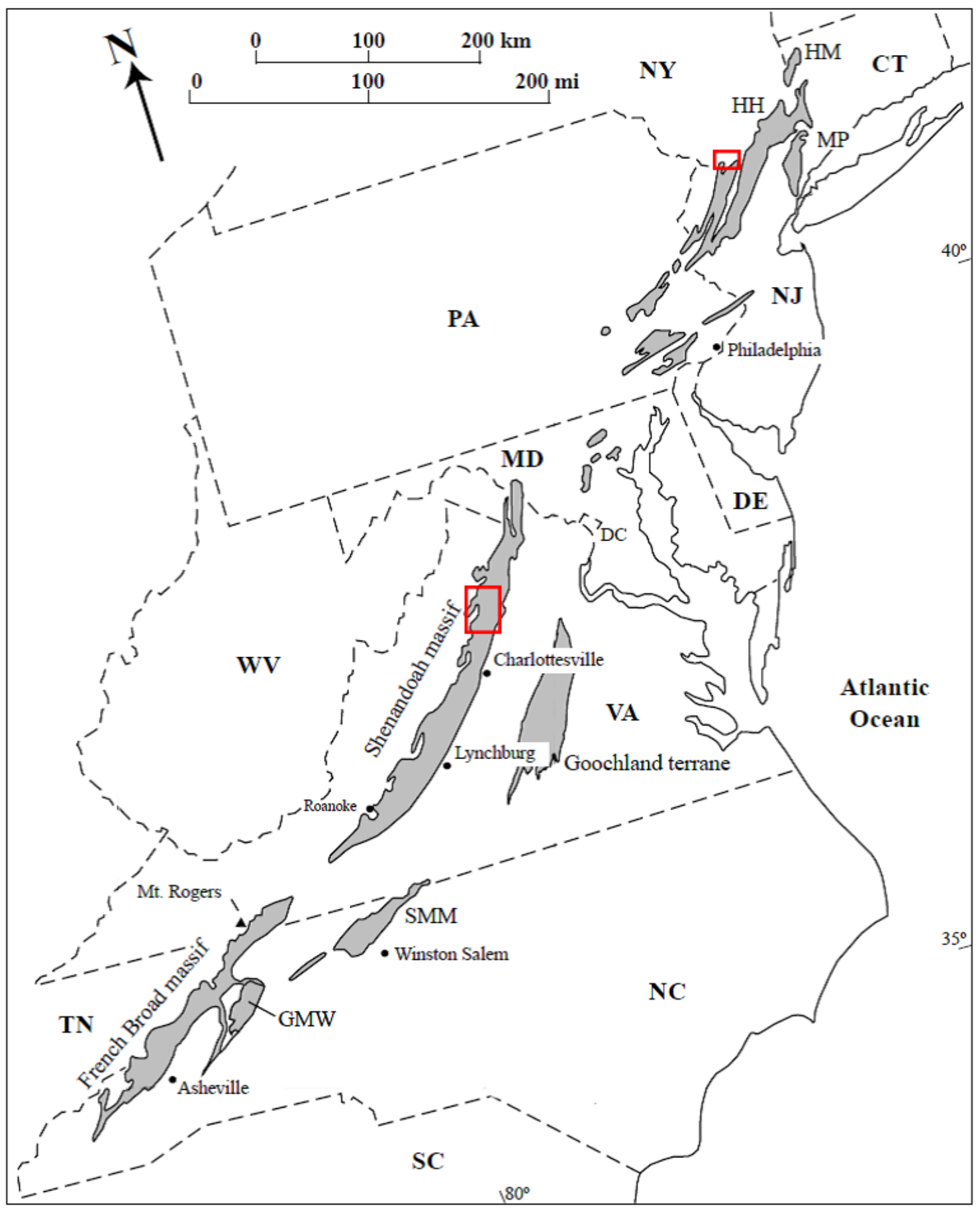

Figure 1.1: Generalized map displaying locations of exposed Grenville-aged rocks in the Laurentian Appalachians. Shaded in grey (after Tollo et al., 2004a, modified from Rankin et al., 1990, Horton et al., 1989, and Glover et al., 1994). Red rectangles outline the study areas. HMHoosatonic massif; HH- Hudson highlands, MP- Manhattan prong; DC- Washington, DC; SMMSauratown Mountains massif; GMW- Grandfather Mountain window. 


\section{CHAPTER II. GEOLOGIC SETTING}

Grenville basement in the Blue Ridge province of the southern and central Appalachians consists of crystalline rocks (ca. 1.35 - $0.95 \mathrm{Ga}$ ), spanning the eastern U.S. 900 km from Georgia to Pennsylvania (Rankin et al., 1989; Aleinikoff et al., 2000, Aleinikoff et al., 2004). During the Grenville orogeny, much of the eastern Laurentian continental crust was accreted to Laurentia and deformed through continental collisional processes (Rivers, 1997). The Elzevirian orogeny (1245 - $1225 \mathrm{Ma}$ ) preceded the Grenville orogeny (although some would consider it to represent an early phase of Rodinian assembly), which includes the accretionary phases of the Shawinigan (1190 $1140 \mathrm{Ma}$ ), the Ottawan (1090 - $1020 \mathrm{Ma})$, and the Rigolet (1000 - 980 Ma; McLelland et al., 1996; Rivers, 1997, 2008).

\section{Blue Ridge Province}

The Blue Ridge province is interpreted to be an outlier of the Grenville province of Canada, and includes crystalline basement rocks dated at ca. 1.0 - 1.3 Ga (Tollo et al., 2004b; Southworth et al., 2010; Tollo et al., 2010). The Shenandoah and French Broad massifs in the Virginia Blue Ridge (Figure 1.2) represent the largest Mesoproterozoic crustal exposure in the Appalachians, and consist of high-grade granitic orthogneisses and charnockites (Bartholomew and Lewis, 1984; Rankin et al., 1989; Tollo et al., 2004a). The smaller, late Precambrian intrusive igneous plutons are generally undeformed, whereas the larger plutons display foliations near major faults and contacts (Tollo et al., 2004a). The Shenandoah massif also contains Neoproterozoic A-type granites and associated volcanic rocks with ages between 760 and 700 Ma that are interpreted to result from post-Rodinian extension and continental rifting (Rankin, 1968; 
Tollo et al., 2004a). In the northern Blue Ridge as well as areas of the southern Appalachians, Neoproterozoic cover rocks overlie the Mesoproterozoic granulite-facies gneisses. Catoctin volcanic units represent the final phase of rifting and the Cambrian metasediments represent the transition to a passive margin "drift” phase for the eastern Laurentian margin bordering Iapetus.

\section{New Jersey - Hudson Highlands}

The Mesoproterozoic Mount Eve granite suite is part of the New Jersey - Hudson Highlands section of the central Appalachians, which extend from northwestern New Jersey to southeastern New York (Figure 1.2). The alkali rich, A-type suite contains numerous undeformed plutons with compositions ranging from quartz monzonite to granite. The plutons intrude Mesoproterozoic basement gneiss over an area of approximately $40 \mathrm{~km}^{2}$ (Gorring et al., 2004). The suite locally contains xenoliths of basement gneiss and amphibolite, and magmatic flow fabrics that occur proximal to intrusive contacts. The presence of a magmatic flow fabric and lack of a solid state fabric is consistent with an absence of evidence for metamorphic overprinting or deformation (Drake et al., 1991; Gorring et al., 2004). Given field relations, geochronology, and chemical composition, the Mount Eve granite suite was determined to be post-kinematic relative to high-grade metamorphic events preserved in the older Grenville orthogneisses. 


\section{CHAPTER III. ANALYTICAL METHODS}

\section{$\mathrm{U}-\mathrm{Pb}$ Geochronology}

Zircon U-Pb geochronology was conducted at the University of California Los Angeles (UCLA) on a CAMECA ims1270 secondary ion mass spectrometer (SIMS). Two representative samples from the Blue Ridge province in Virginia and one sample from the New Jersey - Hudson Highlands province were analyzed: VA 15-1, VA 15-2, and NJ 15-1, respectively. Prior to analysis, all samples were prepared at the University of Kentucky. Approximately $3 \mathrm{~kg}$ of sample was crushed using a jaw crusher into gravelsized chips, then milled into fine-grained sand using a Bico disc mill. The samples were wet sieved to remove clay-sized grains using disposable 250, 125, and $53 \mu \mathrm{m}$ plastic mesh screens to reduce contamination. The $250-125 \mu \mathrm{m}$ and $125-53 \mu \mathrm{m}$ aliquots were rinsed in an ultrasonic bath and dried in an oven. Magnetic iron particles from the disk mill and magnetite were removed using a ceramic block magnet. Heavy minerals were separated from the samples using acetylene tetrabromide (S.G. = 2.96) and methylene iodide $($ S.G. = 3.32). The remaining magnetic minerals were removed using a Frantz Isodynamic Magnetic Separator Model LB-1 at increasing amperage, not to exceed 1.5 Å. Pyrite, monazite, and other impurities were hand-picked and removed to arrive at a relatively pure zircon concentrate.

For preparing a zircon mount consisting of hundreds of grains for assessing the presence of xenocrysts, a round 1" outer diameter plastic mold was affixed to a ceramic tile with a 2 x 2” square of double-sided tape. The zircon concentrate was poured into the mold and periodically rotated and tapped to evenly distribute the grains. Grains of zircon standard AS3 were mounted with sufficient separating distance from unknowns. An 
epoxy was mixed using 5 parts Buehler Epo-Thin ${ }^{\circledR}$ epoxy resin with 2 parts Buehler EpoThin ${ }^{\circledR}$ epoxy hardener, stirred, and ultrasonically agitated to remove air bubbles. The mixture was poured into the mounting ring and left to cure for at least 24 hours. The mounts were sequentially polished using 1200 grit sandpaper, 2000 grit sandpaper, and $0.3 \mu \mathrm{m}$ alumina powder polish.

Backscatter electron (BSE) and cathodoluminescence (CL) images were collected on the University of Kentucky's CAMECA SX50 electron probe microanalyzer and the JEOL IT-100 scanning electron microscope (SEM). These images were used to help determine the presence of xenocrysts, inclusions, and fractures within the zircon grains. This preliminary assessment was used as a guide to locate ideal spot locations during SIMS and LA-ICP-MS analyses.

The mounts were repolished and washed with $1 \mathrm{~N} \mathrm{HCl}$ to reduce common $\mathrm{Pb}$ contamination at UCLA and a $20-40 \mathrm{~nm}$ thick gold coating was applied after drying. Analytical techniques followed those described in Schmitt et al., (2003), with the exception that the multi-collector was added, allowing for decreased analysis time. The mount was sputtered (in order to remove analysis of common lead in gold coating) prior to each analysis using a primary $\mathrm{O}_{2}^{-}$ion beam with a spot size of $30 \mu \mathrm{m}$. Zircon standard AS3 (1099 \pm 1 Ma: Paces and Miller, 1993; Schmitz et al., 2002) was analyzed following every five unknown grains during analysis. Approximately 50 spots, some grains with two spots, were analyzed for each sample. Raw data reduction, including construction of the calibration curve and calculation of isotopic ratios was conducted using the UCLA inhouse program ZIPS. Conventional U-Pb Concordia, Tera-Wasserburg Concordia, 
weighted mean, and relative probability plots were created using Isoplot 4.15 (Ludwig, 2011).

Zircons from NJ 15-1 were also dated at the University of Arizona LaserChron Center using laser ablation-inductively coupled plasma-mass spectrometry (LA-ICP-MS) on a Thermo Element2 multicollector ICP-MS. The mount was prepared by hand-picking prismatic zircon crystals. These analyses were used to assess the quality of data collected at UCLA. Operating conditions used for data collection are described by Gehrels et al., (2008). The primary analytical standard was FC-1, which is the same as AS3 (1099 Ma), with zircon standards SL (563 Ma), and R33 (419 Ma) analyzed as secondary standards.

Approximately 110 spots were analyzed for this sample. Prior to analysis, the surface of the grain was ablated with a Photon Machines Analyte G2 excimer laser equipped with a HelEx ablation cell using a spot diameter of $20 \mu \mathrm{m}$. Helium was used to transport the ablated material to the Element2 ICP-MS. This process involved 5 seconds of measuring peaks with a non-firing laser in order to collect background intensities followed by 10 seconds of measuring peaks with the laser firing. To purge the system of ablated material and save the analysis file, a 20 second delay was set between each sample. Raw U-Th-Pb data reduction was performed at the University of Arizona using a Python decoding routine and the Excel program "E2agecalc" to calculate concentrations, isotopic ratios, and ages for unknowns. U-Pb Concordia, Tera-Wasserburg, weighted mean, and probably density plots were created using Isoplot 4.15 (Ludwig, 2011).

\section{Whole Rock Geochemistry: X-ray Fluorescence}

Whole rock geochemistry using x-ray fluorescence spectrometry (XRF) was performed to determine major, minor, and trace element composition. Six samples from 
the Blue Ridge and five samples from the New Jersey - Hudson Highlands were prepped and analyzed at the Kentucky Geological Survey. The samples were washed to remove organic material, and only non-weathered surfaces were selected for analysis. Billets for thin section analysis were cut from a representative block of sample before further preparation. Approximately $3 \mathrm{~kg}$ of sample was crushed into gravel-sized chips using a jaw crusher, then an aliquot was powdered using a tungsten carbide ring-and-puck shatterbox to produce $60 \mathrm{~mL}$ of very fine powder. Both crusher and ring-and-pucks were cleaned with isopropyl alcohol and compressed air prior to processing a new sample.

Lithium tetraborate glass discs were fused at the Kentucky Geological Survey’s X-ray Analytical Lab. A combination of $4.000 \pm 0.001 \mathrm{~g}$ of sample and $8.000 \pm 0.001 \mathrm{~g}$ of Fluxite ${ }^{\circledR}\left(90 \mathrm{Li}_{2} \mathrm{Br}_{4} \mathrm{O}_{7}: 10 \mathrm{LiF}\right)$ was mixed in a platinum crucible with two drops of $5.8 \mathrm{M}$ $\mathrm{LiBr}$ as a non-wetting agent. The crucible was placed into a Katanax K1 Prime electric fluxer, and the discs were fused at a maximum temperature of $1080^{\circ} \mathrm{C}$. The glass discs were analyzed on a 4-kW Bruker S4 Pioneer wavelength dispersive XRF. The chemical compositions of unknowns were calculated by comparing $x$-ray intensities against standard intensities using Spectra Plus ${ }^{\circledR}$. The software was unable to calculate V, U, Th, and Ga content for the samples due to concentrations below the detection limit; these elements were omitted from the data set. The standards used to construct standard calibration curves are from multiple sources: USGS - (DNC-1, BIR-1, W2a, BCR-2, BHVO-1, BHVO-2, AVG-2, G-2, STM-1, GSP-1), the Irish Geologic Association (OU-3, OU-4, AMH-1, YG-1, KPT-1), the Canadian Certified References Materials Project - (MRG-1, SY-2, S-3), South African Reference Materials - (SARM 4, SARM 50), Centre de Recherches Pétrographiques et Géochimiques - (BE-N) and Chinese 
National Standard - (GBW 07105). Samples were also sent to Washington State University's GeoAnalytical Lab for verification of concentrations, and both sets of analyses are reported (Appendix A). In general, major, minor, and most trace elements are in good agreement, except for $\mathrm{Zr}$, which tended to be much lower in samples analyzed at the KGS.

\section{Rhyolite-MELTS Modeling}

To calculate liquidus compositions and temperatures as the melt crystallizes, multiple crystallization simulations were run using rhyolite-MELTS software (Gualda and Ghiorso, 2012). Rhyolite-MELTS calculates the crystallizing phase assemblage as well as the composition of the remaining melt at each temperature interval. For each sample, the phase assemblage was modeled at $25^{\circ}$ intervals starting from the liquidus. The $\mathrm{M}$ value, a cation ratio deemed most appropriate to reflect variations in melt composition, is calculated using the melt composition at each temperature interval (Watson and Harrison, 1983). A prediction of zircon saturation temperature can then be calculated for each $\mathrm{M}$ at every $25^{\circ}$ interval using the relation:

$$
\begin{gathered}
\mathrm{Zr}_{\mathrm{M}, \mathrm{T}}=496000 \exp \{[3.8+(0.85 *(\mathrm{M}-1))]-12900 \mathrm{~T}(\mathrm{~K})\} \\
\mathrm{M}=(\mathrm{Na}+\mathrm{K}+2 \mathrm{Ca}) /(\mathrm{Al} * \mathrm{Si})
\end{gathered}
$$

The $\mathrm{Zr}$ concentration is calculated using:

$$
\mathrm{Zr}_{\text {melt }}=\mathrm{C}_{0} / \mathrm{F}
$$

where $\mathrm{C}_{0}$ is the initial bulk rock $\mathrm{Zr}$ content and $\mathrm{F}$ is the remaining melt fraction at each temperature. The modeling parameters assume that $\mathrm{Zr}$ is incompatible in all other phases until zircon saturation is reached. The predicted temperature at which zircon begins crystallizing is when $\mathrm{Zr}_{\mathrm{M}, \mathrm{T}}=\mathrm{Zr}_{\text {melt }}$. 


\section{Ti-in-Zircon Thermometry}

In order to further constrain the temperature of zircon formation, we performed Ti-in-zircon geothermometry using Ti concentrations collected in-situ using the StanfordUSGS sensitive high-resolution ion microprobe with reverse geometry (SHRIMP-RG). Trace element analyses (REE) were collected using a 1.5-2.5 $\mathrm{n} \AA \mathrm{O}_{2}^{-}$ion primary beam with a spot diameter of $\sim 23 \mu \mathrm{m}$ and sputter depth of $\sim 1 \mu \mathrm{m}$. Similar analytical methods are further explained in Padilla et al., (2016). The calibration of the Ti-in-zircon thermometer was conducted with quartz and rutile present in the melt during zircon crystallization $\left(\mathrm{a}_{\mathrm{SiO} 2}=1\right.$, $\left.\mathrm{a}_{\mathrm{TiO} 2}=1\right)$ (Watson et al., 2006; Ferry and Watson, 2007). Both quartz and rutile may be absent from the melt in natural systems while zircon is crystallizing, therefore estimates of $\mathrm{a}_{\mathrm{SiO} 2}$ and $\mathrm{a}_{\mathrm{TiO} 2}$ are required for temperature calculations. Values of $\mathrm{a}_{\mathrm{SiO} 2}=1$ (as quartz is present in all samples) and $\mathrm{a}_{\mathrm{TiO} 2}=0.7$ (Ghiorso and Gualda, 2013) were used for all T calculations in this study. The corresponding range of temperatures for $\mathrm{a}_{\mathrm{TiO} 2}=0.6-0.8$ is $30-45^{\circ} \mathrm{C}$ and $\mathrm{asiO} 2=0.8-$ 1.0 is $20-35^{\circ} \mathrm{C}$. The temperature will be underestimated when aTiO2 is overestimated, so $\mathrm{a}_{\mathrm{TiO} 2}=0.7$ is conservative . 


\section{CHAPTER IV. SAMPLE DESCRIPTIONS AND PETROLOGY}

Hand samples were collected from the Shenandoah massif in the Virginia Blue Ridge province and the Mount Eve granite suite in New York. Polished thin sections for petrographic descriptions were prepared for each of the samples. The Blue Ridge samples (VA 15-1, VA 15-2, VA 15-3, VA 15-4, VA 15-5, VA 15-6) were collected in June 2015 and the Mount Eve samples (NJ 15-1, NJ 15-2, NJ 15-3, NJ 15-4, NJ 15-5) were collected in August 2015 by Dr. Dave Moecher.

Samples VA 15-1, VA 15-2, and NJ 15-1 were selected from the Virginia samples for geochronology because of their relatively high $\mathrm{Zr}$ concentrations and zircon yields. These samples are petrologically representative of both the Blue Ridge and Mount Eve study areas. Several previous studies have thoroughly documented the geochemical, petrologic, and structural character of these samples (Tollo et al., 2004a; Tollo et al., 2006; Hughes et al., 1997; Hughes et al., 2004; and Gorring et al., 2004), therefore this section will only provide brief petrologic characteristics of the three analyzed samples.

\section{Blue Ridge Province}

1. VA 15-1, which was collected from the Stage Road Suite of the Lovingston massif is a leucocratic, medium-to-coarse grained gneissic granite, with flattened quartz and feldspar grains and biotite folia defining the gneissic fabric. This sample has greenschist facies metamorphic overprinting characterized by white mica replacing quartz. The sample contains quartz, plagioclase, minor biotite, muscovite, and ilmenite. Potassium feldspar in this sample is dominantly perthitic and the sample lacks pyroxene (Figures 4.1a, 4.1b). Accessory minerals include apatite and zircon. 
2. VA 15-2 was collected from the Pedlar River Charnockite Suite of the Pedlar massif and is a dusky-green, mesocratic, coarse-to-very-coarse grained granite to granodioritic charnockite. The sample is nonfoliated to weakly foliated and contains both ortho- and clinopyroxene, intermediate plagioclase, potassium feldspar, and blue quartz. Red-brown biotite, hornblende, and poikilitic garnet are also present and accessory minerals include rutile, apatite, zircon, magnetite, and ilmenite (Figures 4.2a, 4.2b).

\section{New Jersey - Hudson Highlands}

1. NJ 15-1, which was collected from the Mount Eve granite suite is a pink to light-grey, medium-to-coarse-grained biotite-hornblende granite that lacks foliation or any other observed fabric. The sample is composed dominantly of microperthite, quartz, and oligoclase with minor magnetite and ilmenite and accessory zircon, apatite, and titanite (Figures 4.3a, 4.3b). 


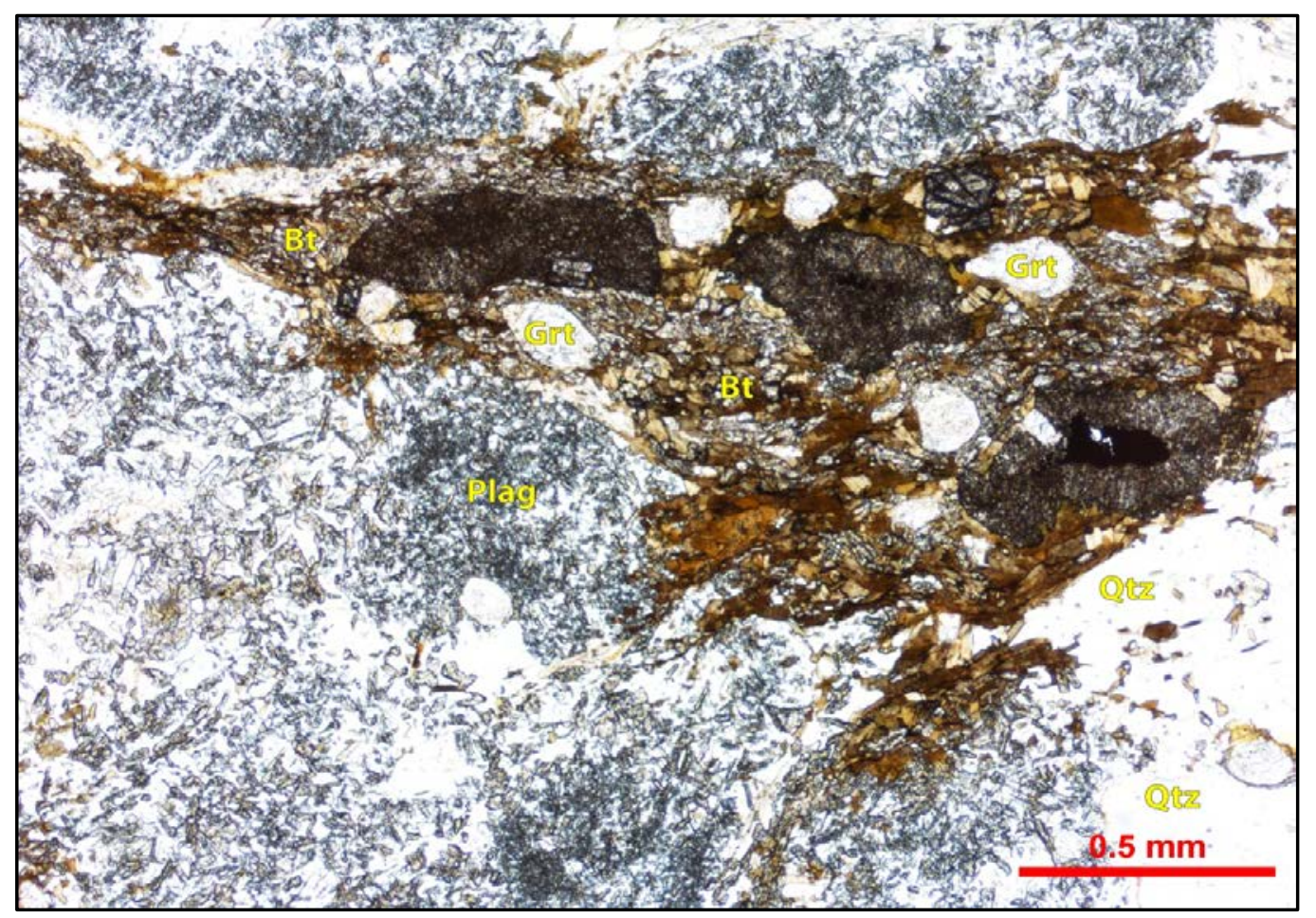

Figure 4.1a: Photomicrograph of VA 15-1 in plane-polarized light. Annotated to show dominant mineral assemblage of gneissic biotite granite with flattened quartz and biotite folia defining fabric.

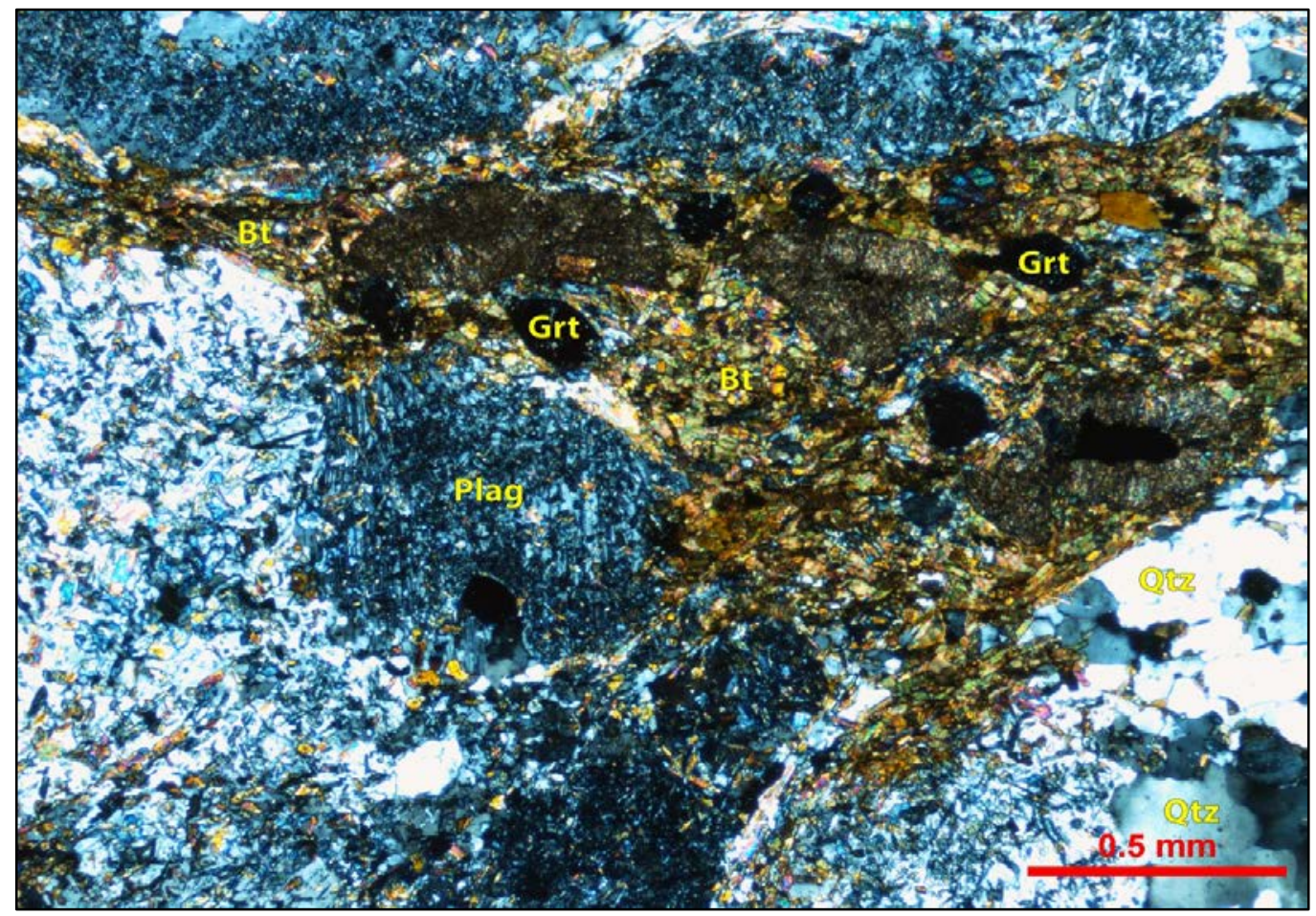

Figure 4.1b: Photomicrograph of VA 15-1 in cross-polarized light. Annotated to show dominant mineral assemblage of gneissic biotite granite and white mica replacing quartz to left of image. 


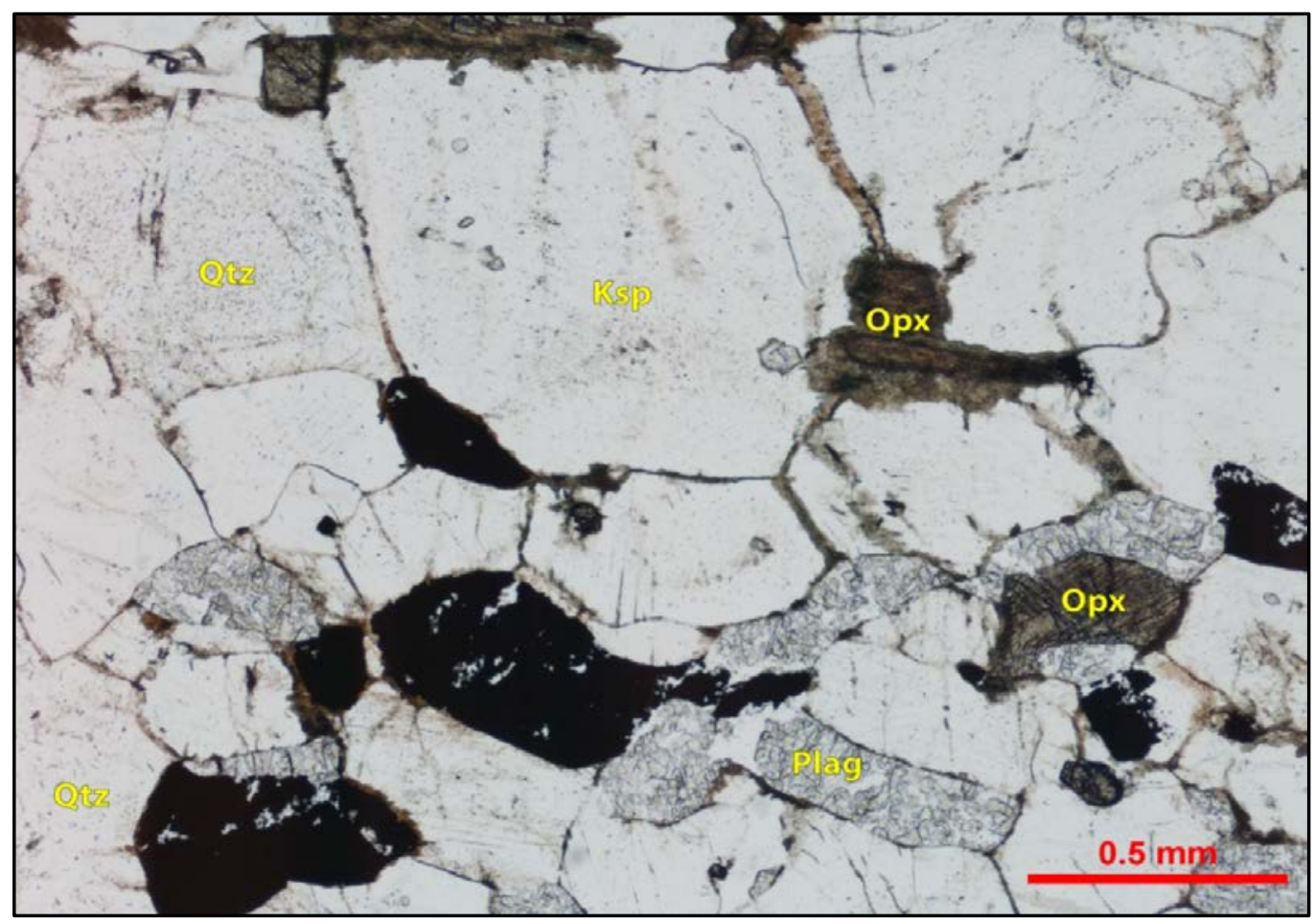

Figure 4.2a: Photomicrograph of VA 15-2 in plane-polarized light. Annotated to show dominant mineral assemblage of granodioritic charnockite and coarseness of grains.

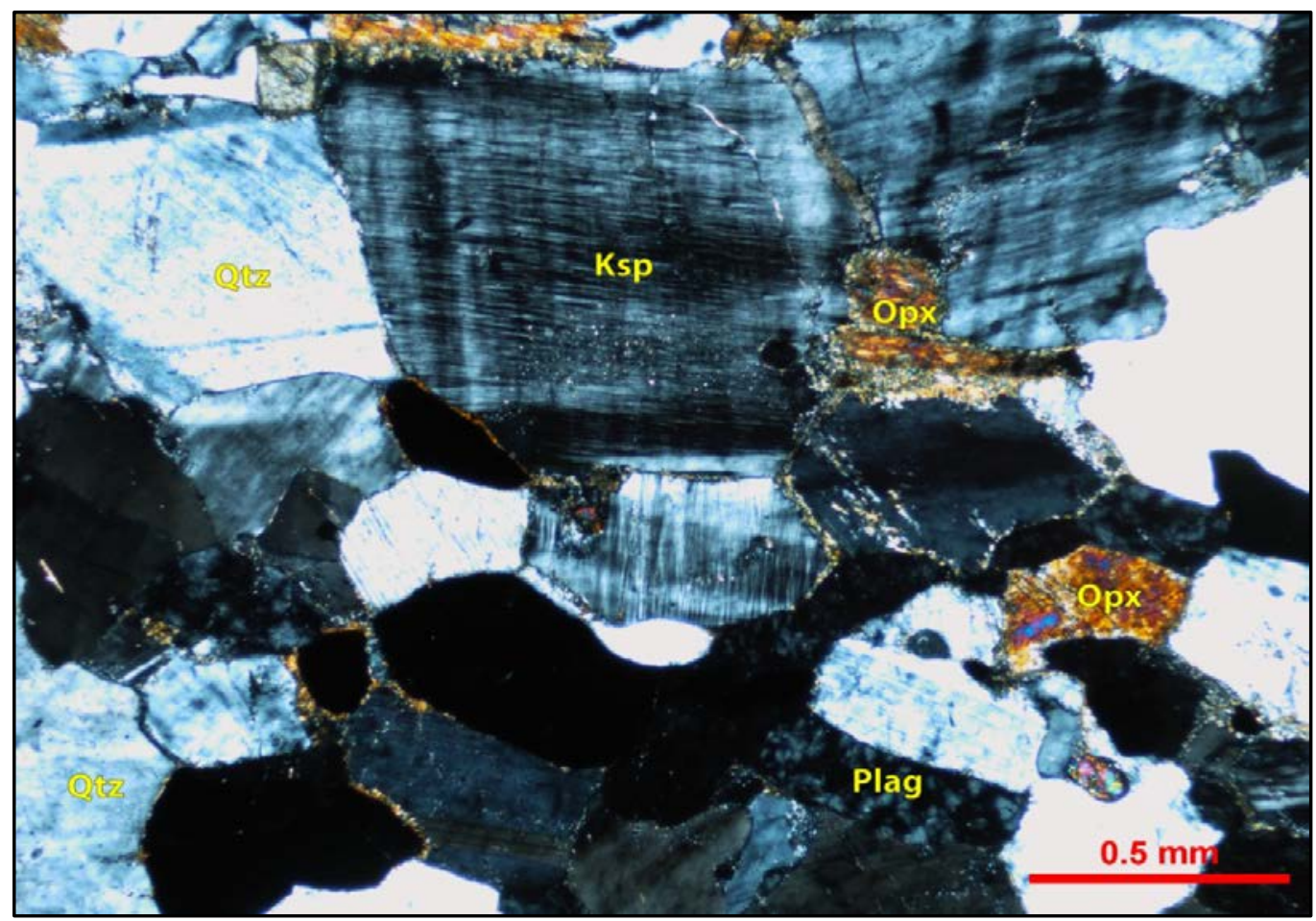

Figure 4.2b: Photomicrograph of VA 15-2 in cross-polarized light. Annotated to show dominant mineral assemblage of granodioritic charnockite, particularly the presence of pyroxenes. 


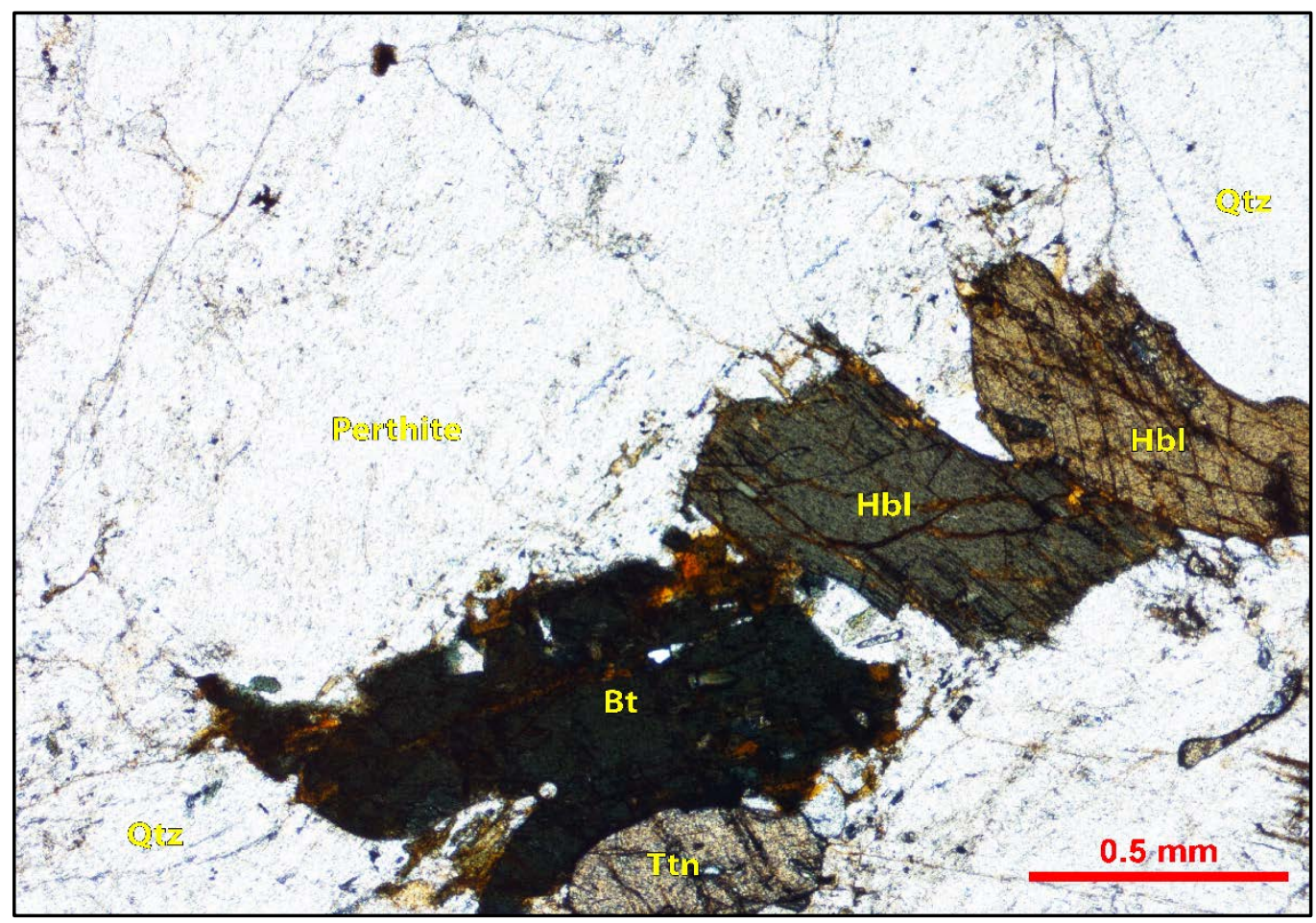

Figure 4.3a: Photomicrograph of NJ 15-1 in plane-polarized light. Annotated to show dominant mineral assemblage of granite and lack of observed fabric.

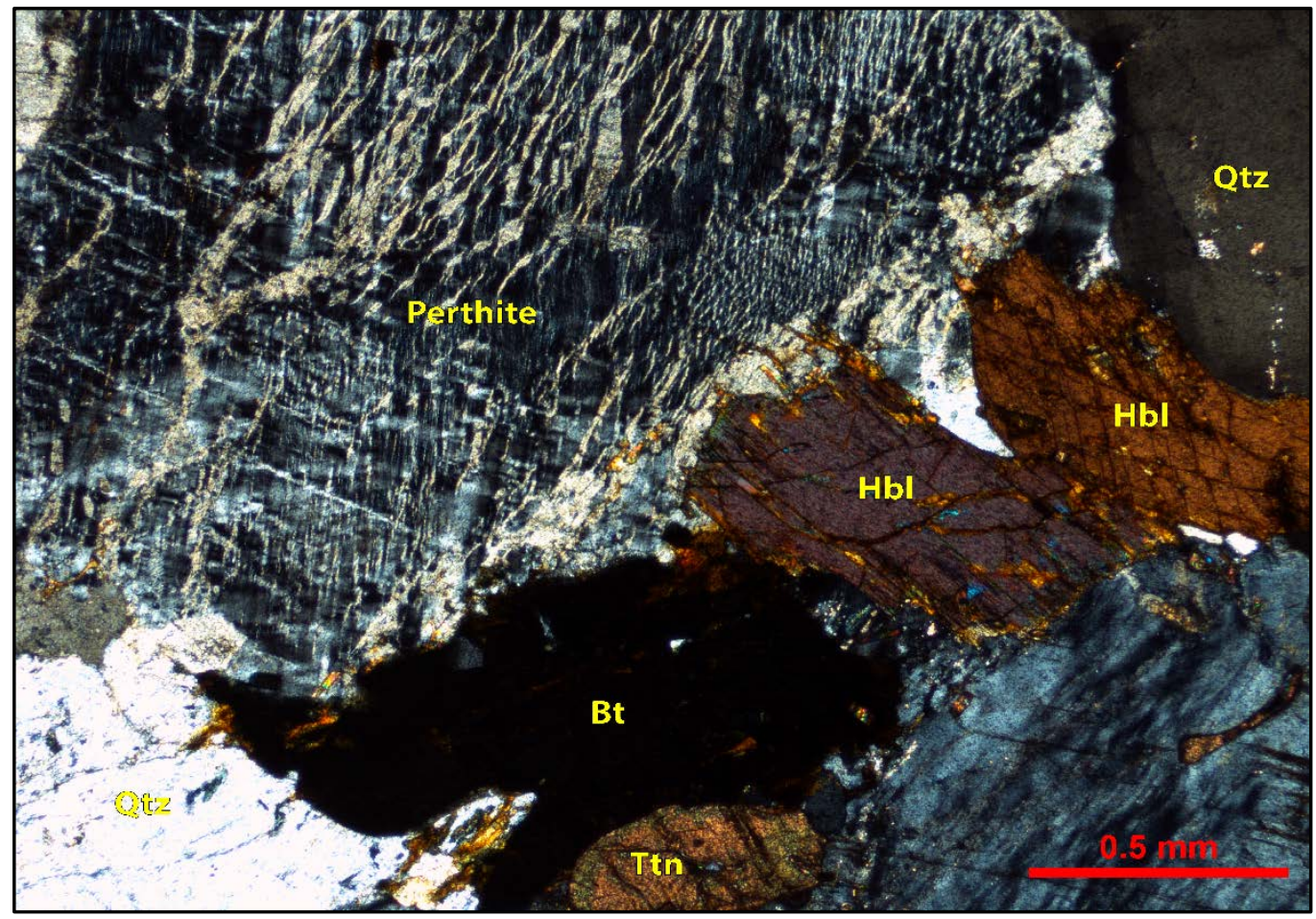

Figure 4.3b: Photomicrograph of NJ 15-1 in cross-polarized light. Annotated to show dominant mineral assemblage of granite and perthitic textures. 


\section{CHAPTER V. RESULTS OF U-PB GEOCHRONOLOGY}

Zircon grains separated from both the Blue Ridge province (VA 15-1, VA 15-2) and the Mount Eve granite suite (NJ 15-1) range from $125 \mu \mathrm{m}$ to $250 \mu \mathrm{m}$ in their longest dimension and were analyzed for $\mathrm{U}$ and $\mathrm{Pb}$ isotopes at the University of California Los Angeles on the CAMECA IMS-1270 multi-collector secondary ion mass spectrometer (SIMS). These analyses were used to both evaluate the presence of xenocrysts, or any other inherited zircon component that would be significantly older than the Grenville component, and to determine magmatic crystallization ages. A description of analytical procedures is found in Chapter III. Raw isotopic ratios, U-Pb ages, and multi-collector gain factor corrections are compiled in Appendix B. To ensure proper calibration and consistency among the three sample mounts, a new calibration of the AS3 zircon standard was conducted for each sample (Figures 5.1, 5.2, 5.3). The accepted crystallization age of AS3 is $1099 \pm 1$ (Paces and Miller, 1993; Schmitz et al., 2002). The weighted mean age of AS3 for each sample run is within $2 \sigma$ error of the accepted age, so no additional age corrections were applied.

Sample "best ages” were calculated from ${ }^{206} \mathrm{~Pb} /{ }^{238} \mathrm{U}$ ages with a precision of 1 standard error. These ages are considered the best estimate for each sample age, as the zircons were very low in $\mathrm{U}$ and thus low in ${ }^{207} \mathrm{~Pb}$. The common $\mathrm{Pb}$ correction thus overestimates the amount of common ${ }^{207} \mathrm{~Pb}$ in these samples. ${ }^{207} \mathrm{~Pb} /{ }^{235} \mathrm{U}$ ages are consequently too young, and the individual multi-collector counts for ${ }^{207} \mathrm{~Pb}$ are low. When data were processed with the common $\mathrm{Pb}$ correction, the ages became reversely discordant. Therefore, only uncorrected data are included in the results below (Figure 5.4). The zircons for each sample display variable degrees of discordancy, and it is 
possible that this effect is artificial. It is also possible that normal discordance could result from lead loss during recrystallization of zircon grains at high temperatures. However, the Mount Eve pluton is unmetamorphosed and the Blue Ridge plutons experienced only greenschist facies Paleozoic metamorphism, potentially indicating the introduction of geochronological lab error.

An age confirmation for sample NJ 15-1 was made at the University of Arizona LaserChron Center on the Thermo Element2 multicollector inductively-coupled plasmamass spectrometer for comparison of age data collected from UCLA. A description of LA-ICP-MS analytical procedures can be found in Chapter III. Calculated isotopic ratios and U-Pb ages are compiled in Appendix B. The "best ages” for solely this sample were determined from ${ }^{206} \mathrm{~Pb} /{ }^{207} \mathrm{~Pb}$ as all grains were older than $900 \mathrm{Ma}$, and the ${ }^{206} \mathrm{~Pb} /{ }^{207} \mathrm{~Pb}$ ages are more precise for rocks that are older than ca. 800 Ma (Gehrels et al., 2008). However, these are only "best ages" as long as the ages are nearly concordant.

\section{Blue Ridge Province}

Orthogneiss sample VA 15-1 contains euhedral to subhedral zircons displaying oscillatory or sector magmatic growth zonation (Figure 5.5). The 33 zircons analyzed included many fractured grains. Most grains are narrowly, albeit faintly, zoned along the edges with broader zones preserved in the cores. This type of zonation pattern is typical for magmatic rocks (Corfu et al., 2003). Greenschist facies metamorphism that postdates crystallization has potentially affected the zonation patterns in this sample, and the secondary textures are more difficult to interpret. Convoluted zoning and oscillatory zoning that is cut off by recrystallization and re-homogenization of grains as well as the 
development of microvein systems is common. Nonetheless, these are probably high temperature (magmatic or subsolidus) modifications to zircon growth textures.

Single spot ${ }^{206} \mathrm{~Pb} /{ }^{238} \mathrm{U}$ ages range from 1088 to 1259 Ma with a weighted mean of $1168 \pm 25$ Ma (Figure 5.6; MSWD = 0.36, probability = 1.00). Although the Concordia and Tera-Wasserburg plots show variable discordancy, ages were obtained from apparent cores (potential xenocrysts) and rims. The ages are generally within error of one another and it is concluded that these are not true inherited components as a significantly older population is not seen.

Zircons from sample VA 15-2 from the Pedlar River Charnockite Suite are subhedral to anhedral. The grains display internal oscillatory magmatic growth zonation as well as unzoned rim overgrowths (Corfu et al., 2003). The forty zircon grains analyzed include few grains with fractures, and some grains are completely and homogeneously recrystallized, although in most grains recrystallization is heterogeneous and localized with convoluted zoning (Figure 5.7). Single spot ${ }^{206} \mathrm{~Pb} /{ }^{238} \mathrm{U}$ ages range from 995 to 1134 Ma. A weighted mean "best age” plot yields an age of $1050 \pm 13$ Ma (Figure 5.8; MSWD $=2.8$, probability $=0.00$ ). The MSWD is consistent with more than one age population. Due to the inability to differentiate significant age variation between the core and rim of these grains, this sample is interpreted to lack xenocrysts, although this is discussed further below.

\section{New Jersey - Hudson Highlands}

Zircon in granite sample NJ 15-1 is euhedral to subhedal and display typical oscillatory magmatic zonation, occasionally faint. The 52 zircon grains analyzed contain few grains with irregular internal mixing as well as sector zoning (Corfu et al., 2003) 
(Figure 5.9). Many zircons are fractured. Most grains are heterogeneous and generally lack thick rim overgrowths, though some grains do have overgrowths. Single spot ${ }^{206} \mathrm{~Pb} /{ }^{238} \mathrm{U}$ ages range from $937 \mathrm{Ma}$ to $1095 \mathrm{Ma}$. A weighted mean “best age” plot yields an age of $1018 \pm 11$ Ma (Figure 5.10a; MSWD = 1.2, probability = 0.14). Analyses were taken from all areas on grains and the core versus rim ages do not indicate the presence of any xenocrystic (inherited) component.

The separate mount examined at the University of Arizona's LaserChron Center contains 96 analysis spots and only those above 95\% concordance are included in the data set (80 spots). Single spot best ages range from 945 Ma to 1055 Ma. A weighted mean "best age” plot yields an age of $1017 \pm 4$ Ma (Figure 5.10b; MSWD = 1.07, probability $=0.14)$. Analyses were taken from all areas on grains and the core versus rim ages again show no evidence for xenocrysts.

\section{Discussion}

The purpose of conducting $\mathrm{U}-\mathrm{Pb}$ geochronology for multiple zircons in each sample was to assess the presence of xenocrystic cores and older inherited components. If xenocrysts were found, further analytical work cannot be continued on those grains because we have no way to identify the initial magmatic conditions under which the original xenocryst formed. Additionally, whole-rock Zr content may be an overestimate of parent magma composition when xenocrysts are abundant. Zircons from the three samples are lacking inherited components, leading to the conclusion that these high-Zr granitoids have been crystallized at high temperatures and are "hot” granites.

Previous studies have dated a similar Stage Road Suite sample (VA 15-1) using $\mathrm{U}-\mathrm{Pb}$ and determined that this suite of rocks is representative of Lovingston massif 
country rock that formed ca. 1150 Ma (Aleinikoff et al., 2000; Hughes et al., 2004). Data from the current study suggest a more refined age of $1168 \pm 25$ Ma. The Stage Road Suite is also possibly equivalent to a metamorphic episode that led to the development of the gneissic foliations at 1160 - $1140 \mathrm{Ma}$ and high-silica charnockite formation in the northern Pedlar massif (Tollo et al., 2004a).

Sample VA 15-2 has also been dated using U-Pb and because of complex isotopic systematics, the date of $>1145$ Ma (Aleinikoff et al., 2000) is unreliable. As shown in Figure 5.7, the zircons display very heterogeneous zoning patterns and various degrees of recrystallization. Though this study indicates that the charnockite sample is Mesoproterozoic and $1050 \pm 13 \mathrm{Ma}$ in age, no xenocrysts were found. There remains uncertainty with regard to grain textures and age. It is possible that the seemingly bimodal population within best ages is due to recrystallization or dissolution of antecrysts during metamorphism, but because the sample lacks a significantly older component we do not believe these analyses to be indicative of true xenocrysts.

Sample NJ 15-1 has been previously dated using U-Pb to have an age of $1020 \pm 4$ Ma (Drake et al., 1991) and the Mesoproterozoic date coincides with this study’s SIMS age of $1018 \pm 11 \mathrm{Ma}$. The sample dated using LA-ICP-MS at the University of Arizona has a similar age of $1017 \pm 5 \mathrm{Ma}$ and confirms this age estimate. This sample contains zircons with similar morphologies to VA 15-1: mostly homogenous and typical magmatic zonation patterns. We do see large (up to $\sim 15 \mu \mathrm{m}$ ), thick dark CL overgrowths on a handful of grains, and the general morphologies are comparable to those seen in Siebel et al. (2012), where they are interpreted as indicators of UHT metamorphic conditions and intracrustal recycling. 
VA 15-1

AS3 Standard
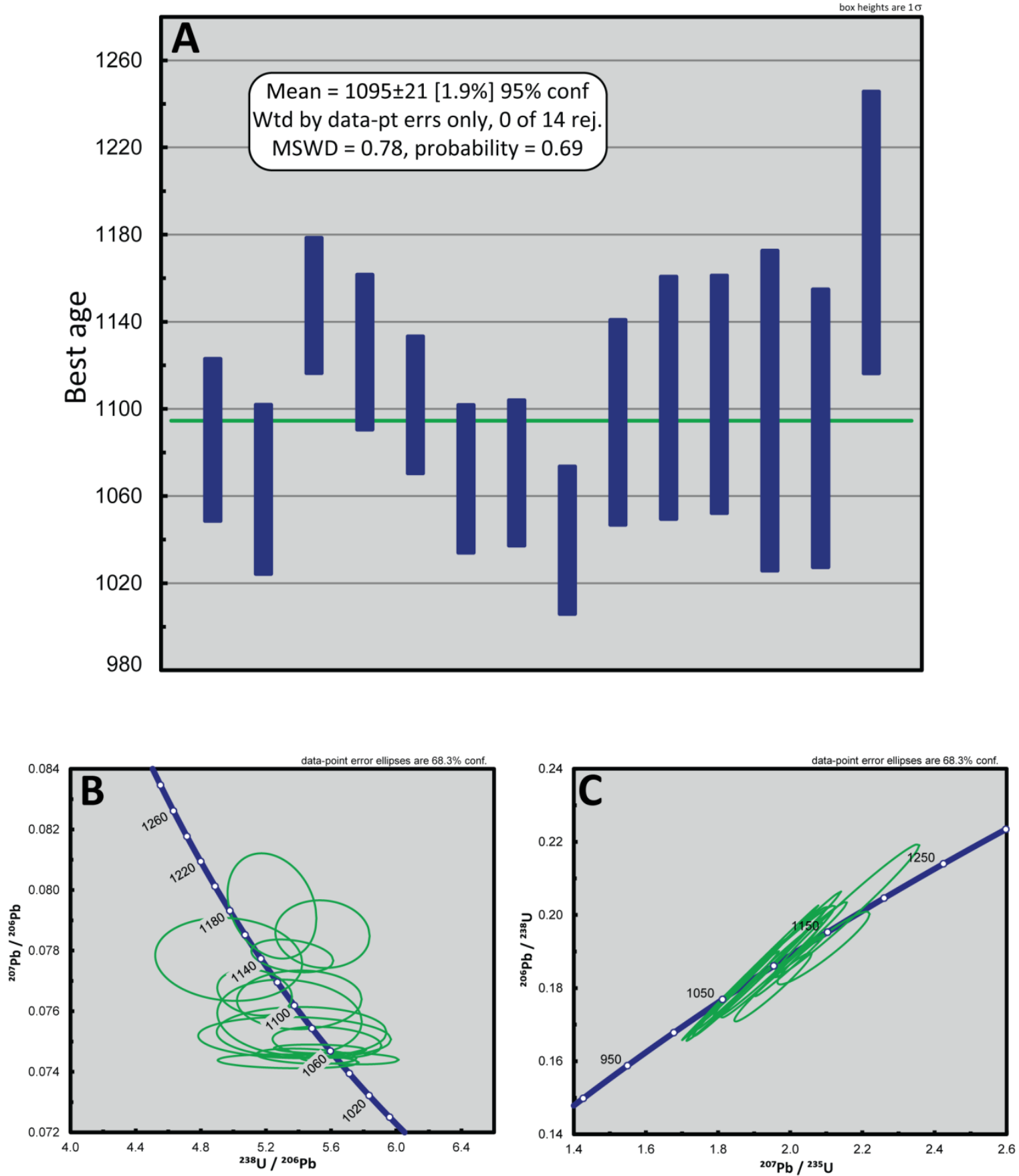

Figure 5.1: Results of SIMS analysis of AS3 zircon standard from sample VA 15-1. Data were not corrected for common $\mathrm{Pb}$. (a) Weighted mean age plot of ${ }^{206} \mathrm{~Pb} /{ }^{238} \mathrm{U}$ ages with $1 \sigma$ errors. (b) Tera-Wasserburg diagram of all data. (c) Concordia diagram of all data. 

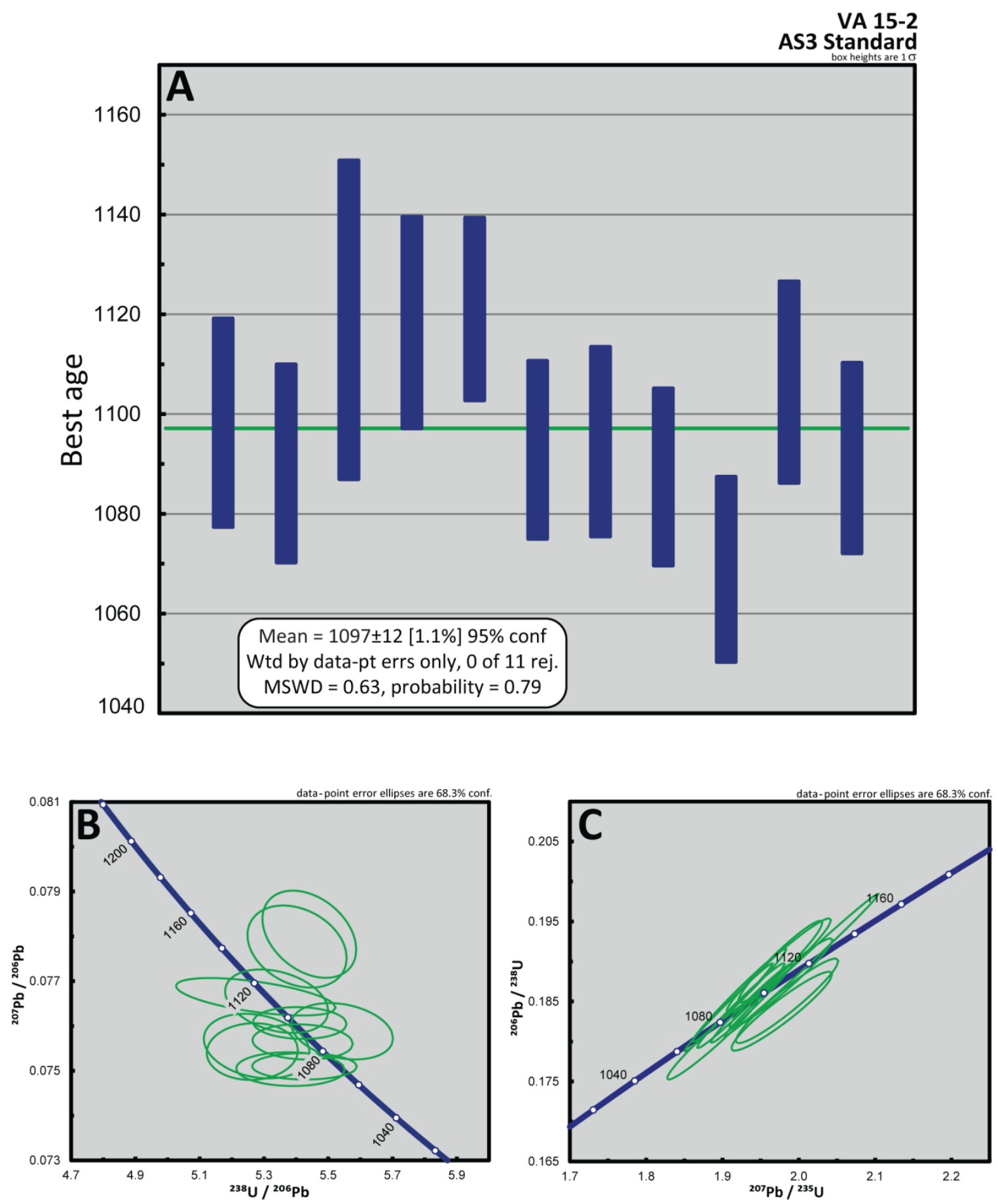

Figure 5.2: Results of SIMS analysis of AS3 zircon standard from sample VA 15-2. Data were not corrected for common $\mathrm{Pb}$. (a) Weighted mean age plot of ${ }^{206} \mathrm{~Pb} /{ }^{238} \mathrm{U}$ ages with $1 \sigma$ errors. (b) Tera-Wasserburg diagram of all data. (c) Concordia diagram of all data. 
NJ 15-1

AS3 Standard
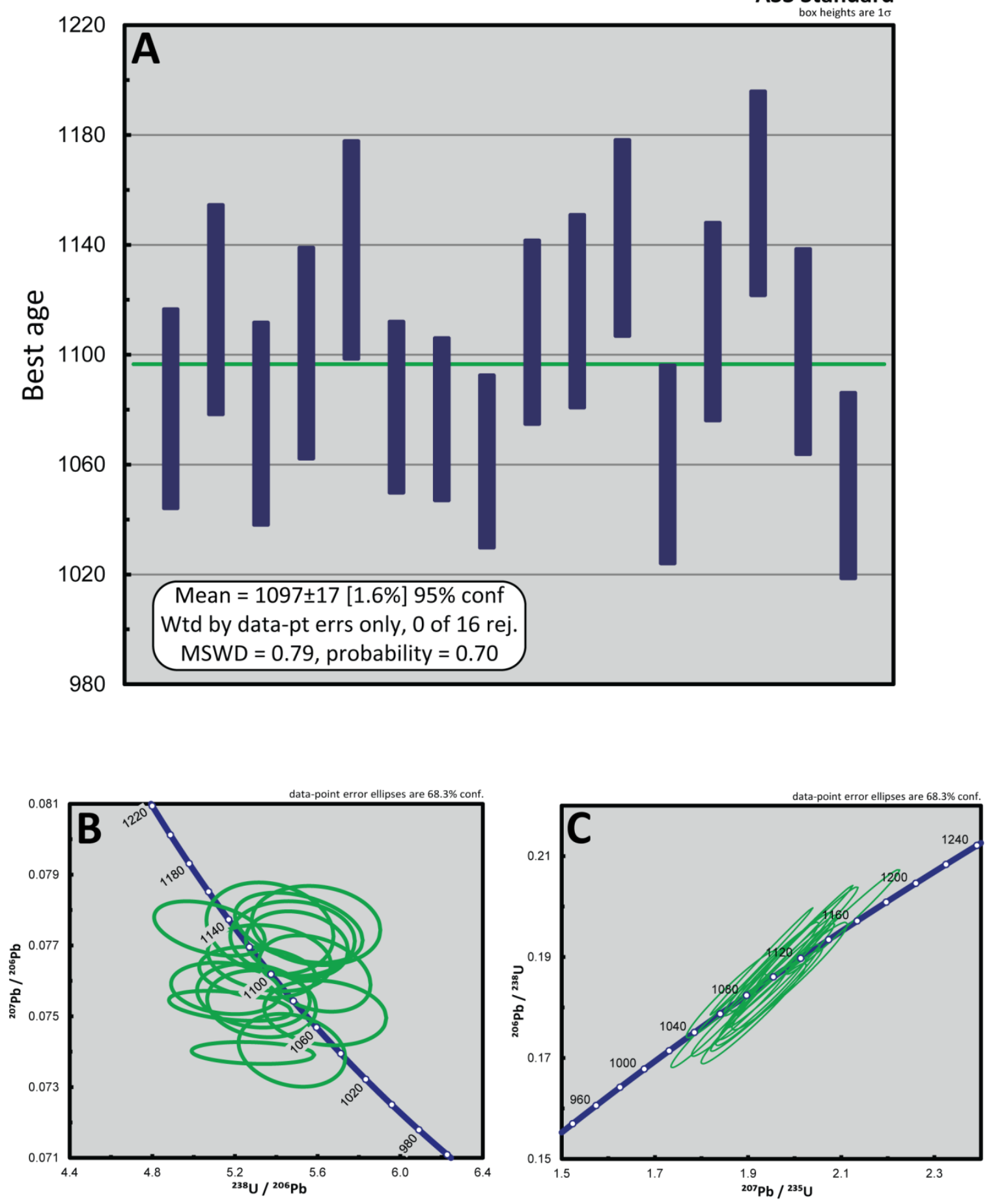

Figure 5.3: Results of SIMS analysis of AS3 zircon standard from sample NJ 15-1. Data were not corrected for common $\mathrm{Pb}$. (a) Weighted mean age plot of ${ }^{206} \mathrm{~Pb} /{ }^{238} \mathrm{U}$ ages with $1 \sigma$ errors. (b) Tera-Wasserburg diagram of all data. (c) Concordia diagram of all data. 


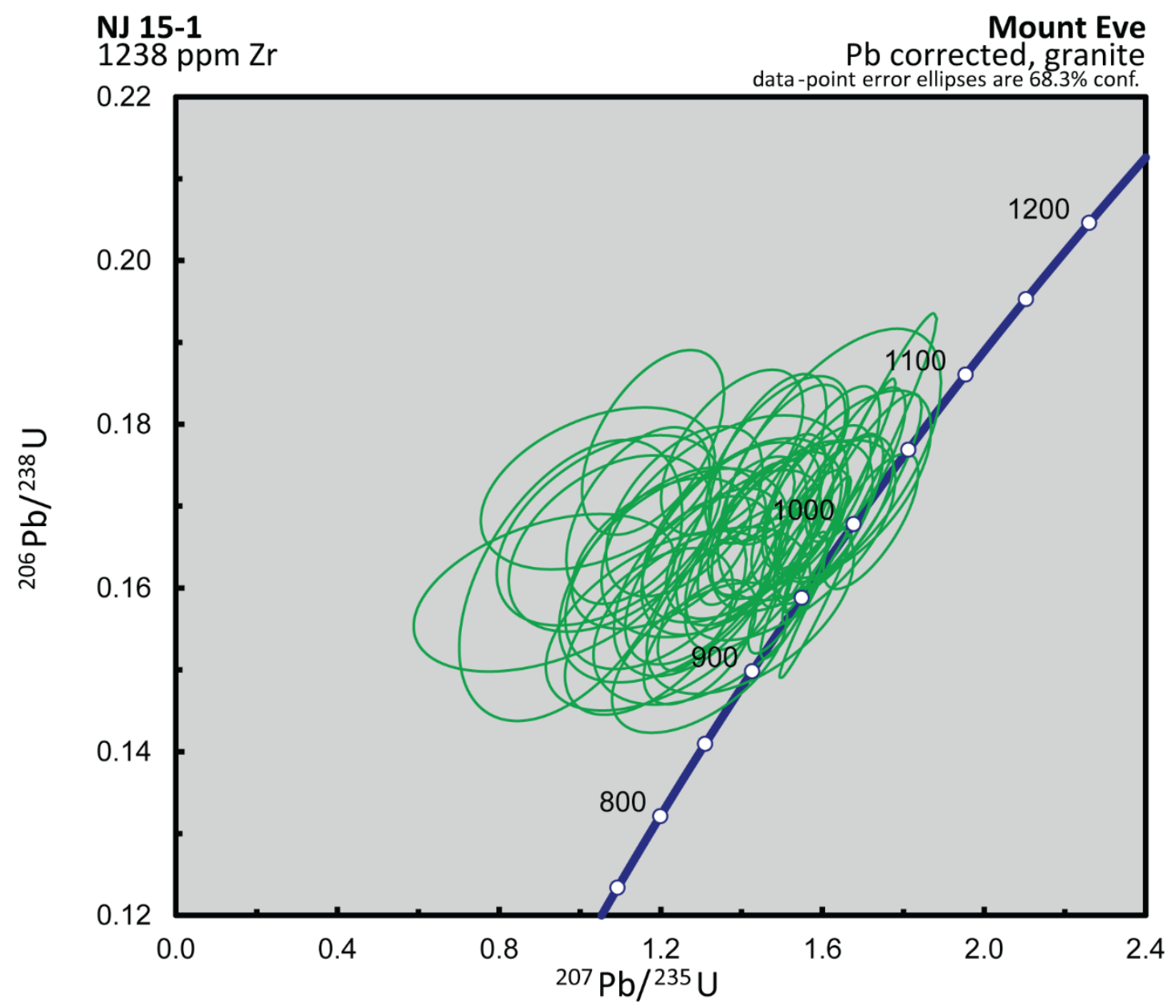

Figure 5.4: Pb-corrected results of SIMS analysis of grains from sample NJ 15-1. Ages are reversely discordant when applying the UCLA common Pb correction. 

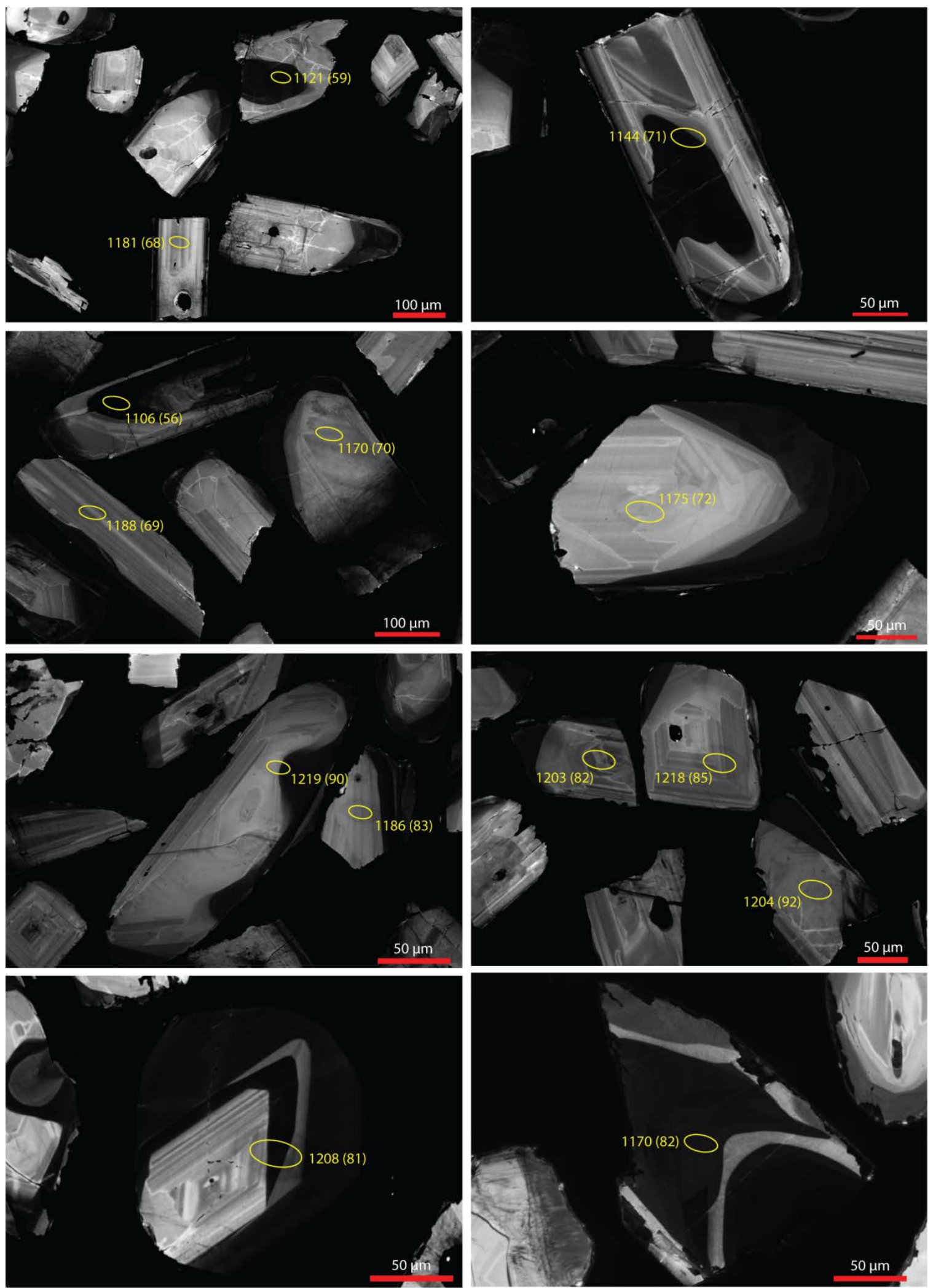

Figure 5.5: CL images of VA 15-1 zircon grains. Yellow ellipses represent $30 \mu \mathrm{m}$ analysis spot locations. Ages with 1 standard error are shown beside each spot. 

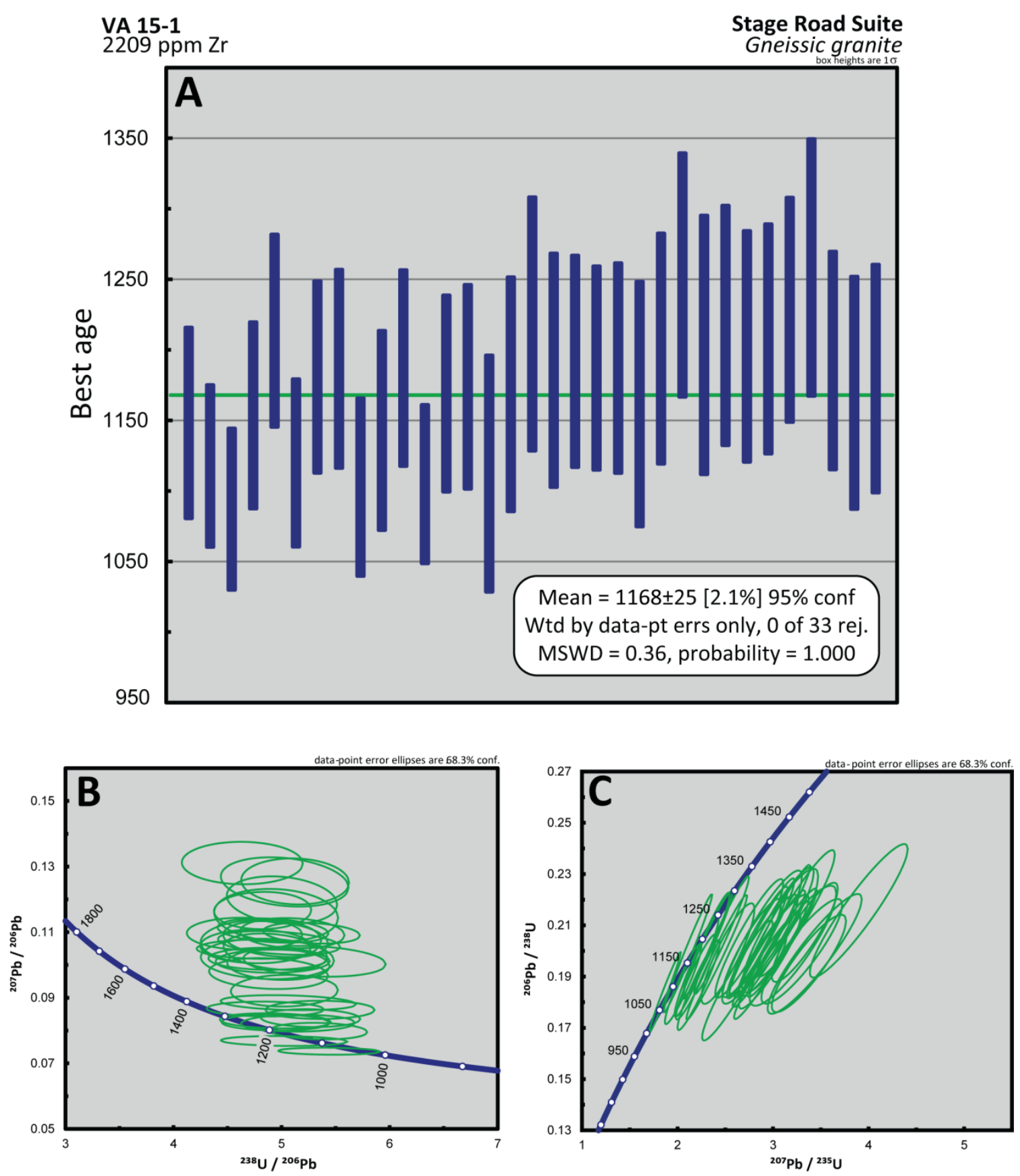

Figure 5.6: Results of SIMS analysis of zircon grains from sample VA 15-1. Data were not corrected for common $\mathrm{Pb}$. (a) Weighted mean age plot of ${ }^{206} \mathrm{~Pb} /{ }^{238} \mathrm{U}$ ages with $1 \sigma$ errors. (b) Tera-Wasserburg diagram of all data. (c) Concordia diagram of all data. 

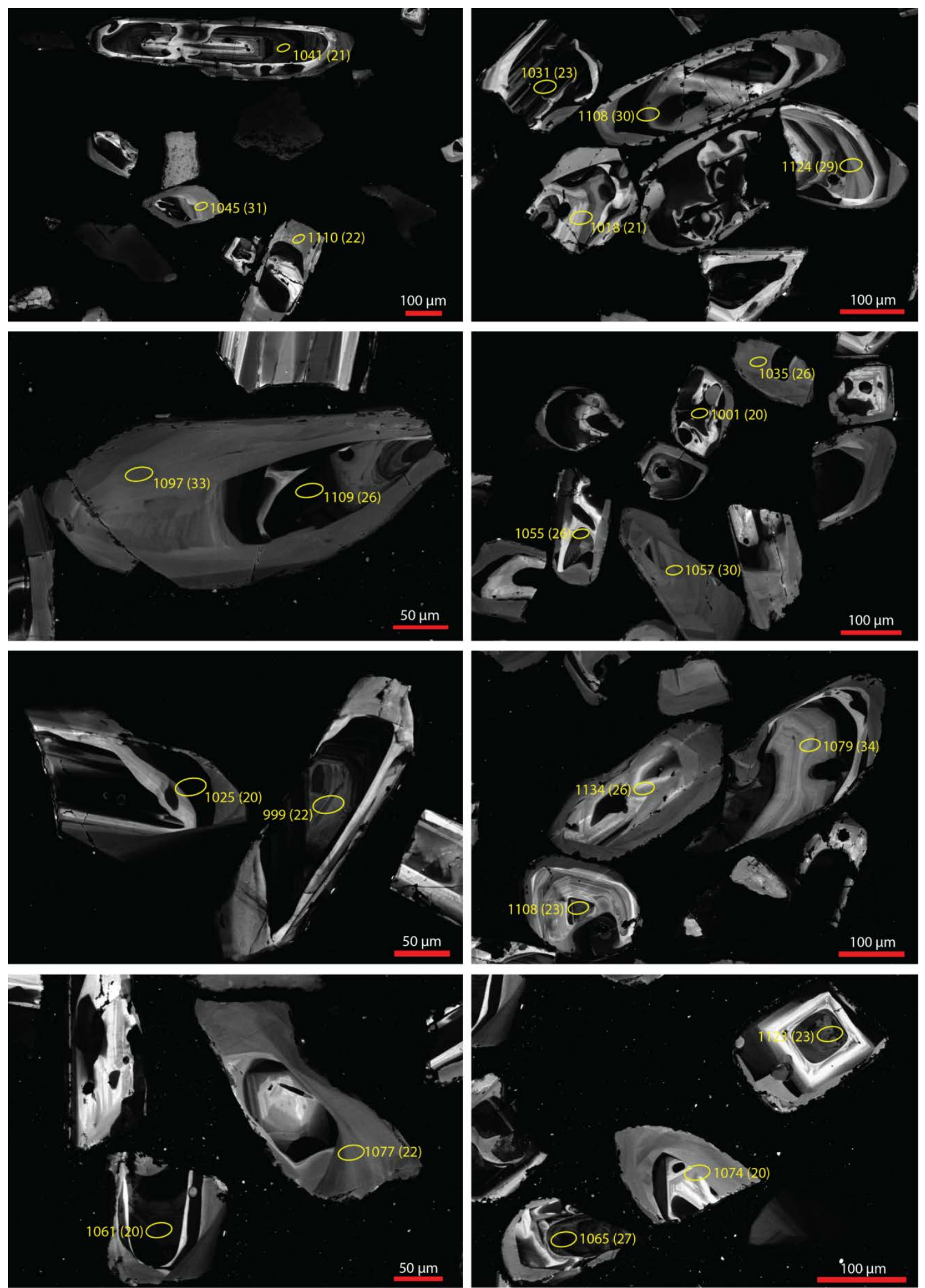

Figure 5.7: CL images of VA 15-2 zircon grains. Yellow ellipses represent $30 \mu \mathrm{m}$ analysis spot locations. Ages with 1 standard error are shown beside each spot. 

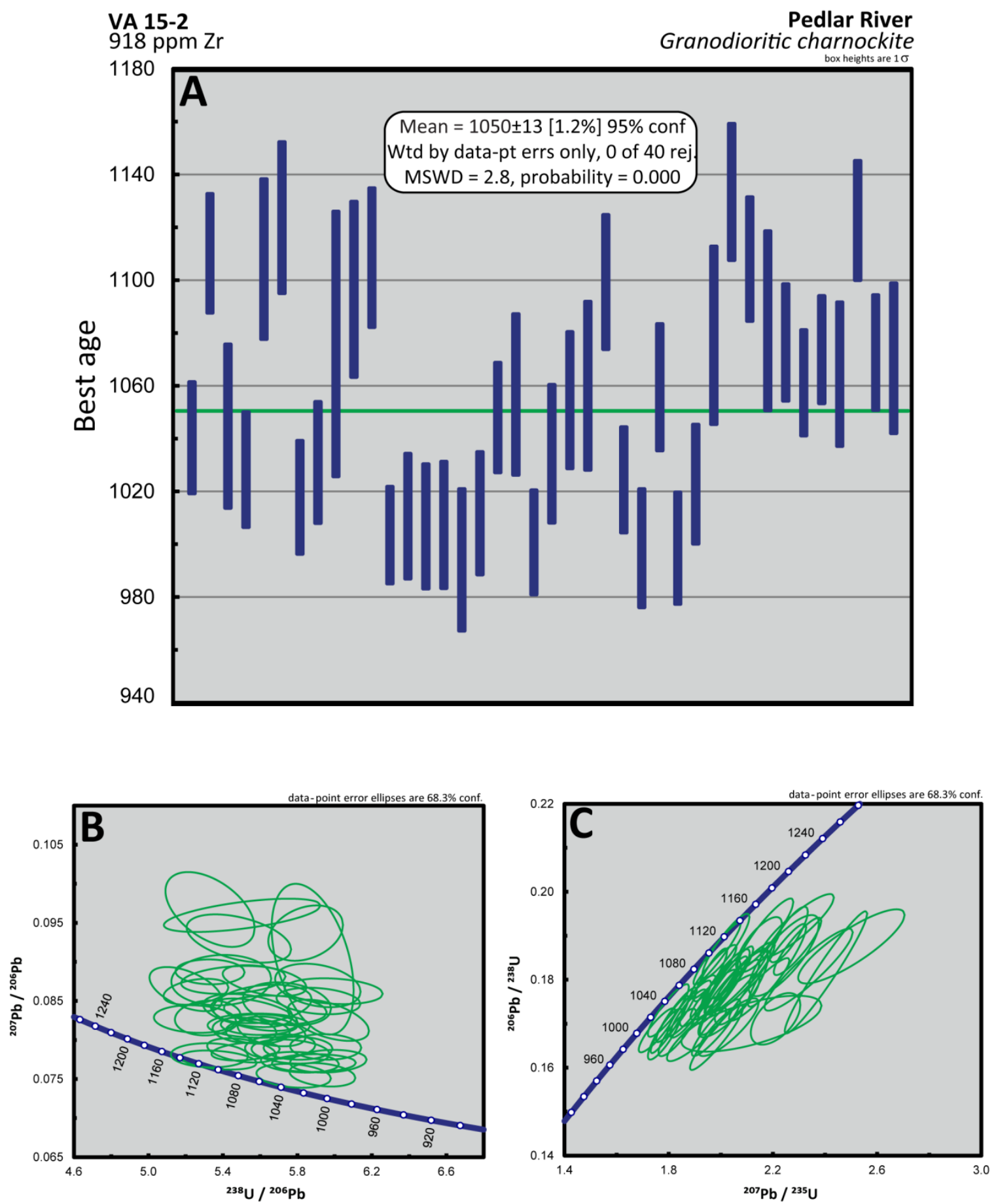

Figure 5.8: Results of SIMS analysis of zircon grains from sample VA 15-2. Data were not corrected for common $\mathrm{Pb}$. (a) Weighted mean age plot of ${ }^{206} \mathrm{~Pb} /{ }^{238} \mathrm{U}$ ages with $1 \sigma$ errors. (b) Tera-Wasserburg diagram of all data. (c) Concordia diagram of all data. 

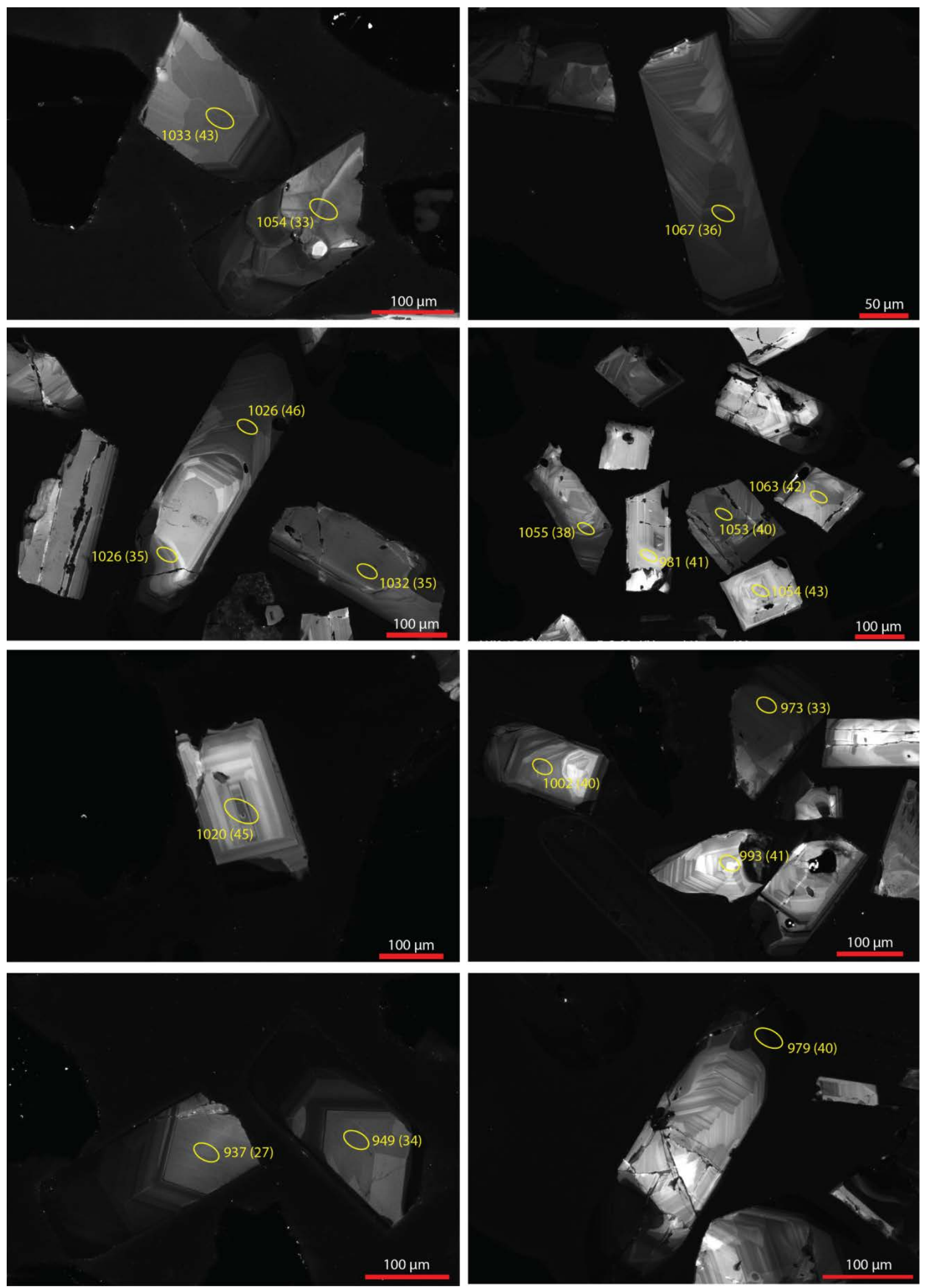

Figure 5.9: CL images of NJ 15-1 zircon grains. Yellow ellipses represent $30 \mu \mathrm{m}$ analysis spot locations. Ages with 1 standard error are shown beside each spot. 

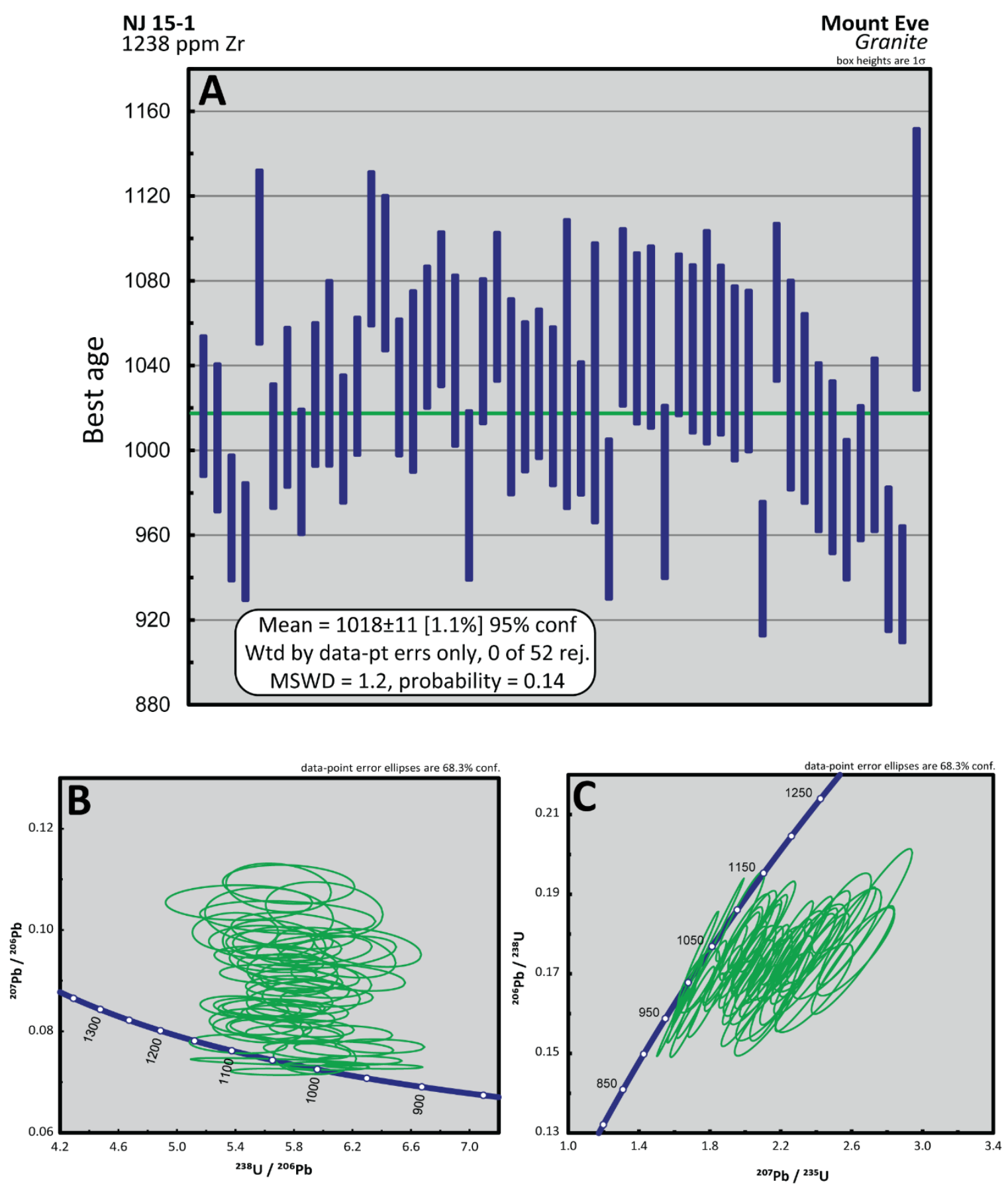

Figure 5.10a: Results of SIMS analysis of zircon grains from sample NJ 15-1. Data were not corrected for common $\mathrm{Pb}$. (a) Weighted mean age plot of ${ }^{206} \mathrm{~Pb} /{ }^{238} \mathrm{U}$ ages with $1 \sigma$ errors. (b) Tera-Wasserburg diagram of all data. (c) Concordia diagram of all data. 
NJ 15-1

$1238 \mathrm{ppm} \mathrm{Zr}$

Mount Eve

box heights are 16
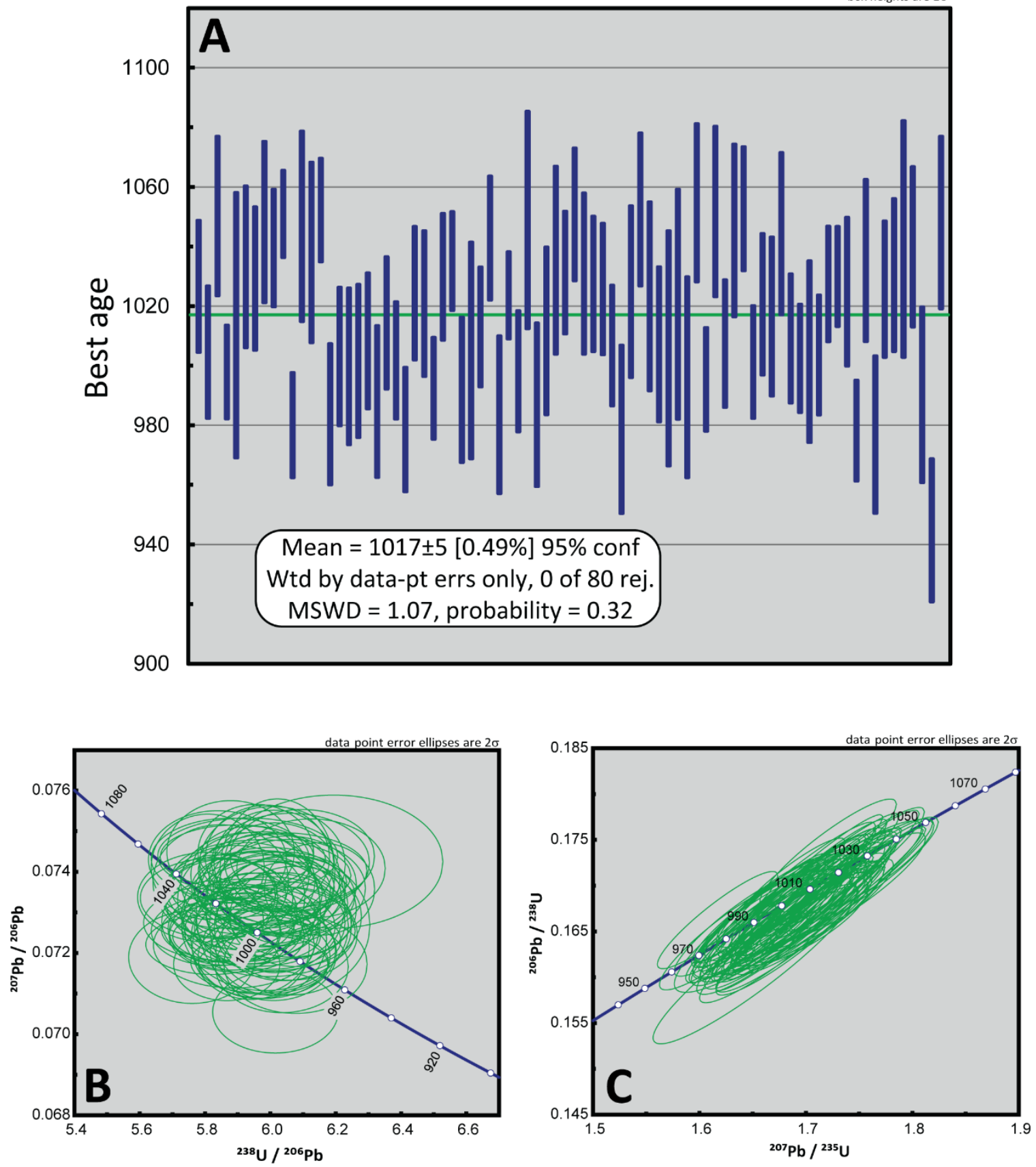

Figure 5.10b: Results of LA-ICP-MS analysis of zircon grains from sample NJ 15-1. Data were corrected for common $\mathrm{Pb}$. (a) Weighted mean age plot of ${ }^{206} \mathrm{~Pb} /{ }^{207} \mathrm{~Pb}$ ages with $1 \sigma$ errors. (b) Tera-Wasserburg diagram of all data. (c) Concordia diagram of all data. 


\section{CHAPTER VI. RESULTS OF CRYSTALLIZATION MODELING}

In order to predict crystallization histories and the evolution of $\mathrm{Zr}$ concentration throughout crystallization of a zircon-bearing granite, this study used rhyolite-MELTS (Gualda et al., 2012) quantitative thermodynamic and geochemical modeling software. This program was chosen over MELTS (Ghiorso and Sack, 1995) because rhyoliteMELTS is calibrated to handle quartz-feldspar saturation concurrently with pressure in high-silica systems. The three samples chosen for geochronology (VA 15-1, VA 15-2, NJ 15-1) were modeled using whole-rock elemental data from XRF analyses (Appendices A and C). Details of modeling parameters are presented in Chapter III. Rhyolite-MELTS allows users to derive simulated temperatures at which zircon saturation in the melt is reached, or the upper limit of the range over which zircon will crystallized. This temperature can then be compared with the zircon saturation temperature $\left(\mathrm{T}_{\mathrm{Zr}}\right)$ calculated from whole-rock bulk compositions as well as Ti-in-zircon temperatures to be discussed in the following section.

Two simulations were run for each of the three samples using variable bulk-rock $\mathrm{H}_{2} \mathrm{O}$ contents: original $\mathrm{H}_{2} \mathrm{O}$ wt. \% measured by LOI as a lower control and $1.0 \% \mathrm{H}_{2} \mathrm{O}$ as an upper control to assess the effect of fluid saturation conditions in the initial melt. Realistically, initial melt conditions are likely to be wetter than these nominal anhydrous values and this is a key drawback when using rhyolite-MELTS (models cannot be run with $0 \% \mathrm{H}_{2} \mathrm{O}$ ). Typical A-type granites generated in crustal environments have much higher water contents than previously considered: at $500 \mathrm{MPa}$ and a temperature of 800 ${ }^{\circ} \mathrm{C}$, various granitic compositions have been experimentally found to contain approximately 10 wt. \% $\mathrm{H}_{2} \mathrm{O}$ (Holtz et al., 2001). As such, rhyolite-MELTS may 
underestimate initial magmatic temperatures at the source. In addition to calculating the crystallizing phase assemblage compositions (Figure 6.1), rhyolite-MELTS also calculates the composition of the remaining melt for each temperature step (in this case, $25{ }^{\circ} \mathrm{C}$ for internal precision). The remaining melt compositions are then used to calculate the $\mathrm{M}$ value at each temperature, and a predicted zircon saturation temperature was calculated for each M using the equation (Watson and Harrison, 1983):

$$
D^{Z r, z i r c o n / m e l t}=\{-3.8-[0.85(M-1)]\}+12,900 / T,
$$

where $D^{Z r, z i r c o n} /$ melt is the ratio of Zr ppm in zircon $(\sim 476,000 \mathrm{ppm})$ to the concentration of $\mathrm{Zr}$ in the saturated melt and $\mathrm{M}$ is a cation ratio $[(\mathrm{Na}+\mathrm{K}+2 \mathrm{Ca}) /(\mathrm{Al} * \mathrm{Si})]$ that is dependent on the degree to which the melt is peraluminous, metalumninous, or peralkaline. $\mathrm{T}$ is in Kelvin but will be reported as ${ }^{\circ} \mathrm{C}$. When rearranged to solve for $\mathrm{T}$, our geothermometer, the equation yields:

$$
T_{Z r}=12,900 /\left[2.95+0.85 M+\ln \left(496,000 / Z r_{\text {melt }}\right)\right]
$$

Zr concentration of the evolving melt is calculated using:

$$
Z r_{\text {melt }}=\mathrm{C}_{0} / \mathrm{F}
$$

where $\mathrm{C}_{0}$ is the initial bulk-rock $\mathrm{Zr}$ concentration and $\mathrm{F}$ is the fraction of remaining melt at each temperature, calculated from rhyolite-MELTS. The melt is saturated in zircon at the temperature at which $\mathrm{Zr}_{\mathrm{T}, \mathrm{M}}=\mathrm{Zr}_{\text {melt, }}$, the point of intersection of the two respective curves, which is the predicted onset of zircon crystallization (Figure 6.2).

\section{Blue Ridge Province}

Orthogneiss sample VA 15-1 contains 61.85\% $\mathrm{SiO}_{2}, 0.62 \% \mathrm{LOI}$, and 2209 ppm Zr (Appendices A and C). The first simulation at 0.60 wt. $\% \mathrm{H}_{2} \mathrm{O}$ yields a liquidus temperature of $\sim 1060{ }^{\circ} \mathrm{C}(\mathrm{M}=1.79$, Figure 6.2$)$. The second simulation at 1.0 wt. $\% \mathrm{H}_{2} \mathrm{O}$ 
yields a crystallization temperature of $\sim 1043{ }^{\circ} \mathrm{C}$ (Figure 6.2), decreasing the liquidus temperature by approximately $17^{\circ} \mathrm{C}$. The modeled onset of zircon crystallization is $\sim 28$ ${ }^{\circ} \mathrm{C}$ higher than $\mathrm{Tzr}$.

Granodioritic charnockite sample VA 15-2 contains 58.18\% $\mathrm{SiO}_{2}, 0 \% \mathrm{LOI}$, and $918 \mathrm{ppm} \mathrm{Zr}$ (Appendices A and C). The first simulation at $0.1 \mathrm{wt}$ \% $\mathrm{H}_{2} \mathrm{O}$ yields a liquidus temperature of $\sim 1024^{\circ} \mathrm{C}(\mathrm{M}=2.09$, Figure 6.2). The second simulation at 1.0 wt. $\% \mathrm{H}_{2} \mathrm{O}$ yields a liquidus temperature of $\sim 996{ }^{\circ} \mathrm{C}$ (Figure 6.2), decreasing the liquidus temperature by approximately $28{ }^{\circ} \mathrm{C}$. The modeled onset of zircon crystallization is $\sim 126$ ${ }^{\circ} \mathrm{C}$ higher than $\mathrm{Tzr}$.

New Jersey - Hudson Highlands

Granite sample NJ 15-1 contains 66.97\% $\mathrm{SiO}_{2}, 0.37 \%$ LOI, and 1238 ppm Zr (Appendices A and C). The first simulation at 0.37 wt. $\% \mathrm{H}_{2} \mathrm{O}$ yields a liquidus temperature of $\sim 983{ }^{\circ} \mathrm{C}\left(\mathrm{M}=1.79\right.$, Figure 6.2). The second simulation at 1.0 wt. $\% \mathrm{H}_{2} \mathrm{O}$ yields a liquidus temperature of $\sim 979^{\circ} \mathrm{C}$, decreasing the liquidus temperature by approximately $4{ }^{\circ} \mathrm{C}$. The modeled onset of zircon crystallization is $\sim 23^{\circ} \mathrm{C}$ higher than $\mathrm{T}$ zr.

\section{Discussion}

In the models, liquidus temperatures for the three samples range from 983 - 1060 ${ }^{\circ} \mathrm{C}$. The first crystallizing phase for VA $15-1$ is orthopyroxene. The first crystallizing phase for VA 15-2 is quartz with orthopyroxene at nearly the same time. The first crystallizing phase for NJ 15-1 is orthopyroxene. The highest M value calculated was VA 15-2 at 2.09. This sample also has the lowest $\mathrm{Zr}$ ppm at 918 and largest difference in modeled $\mathrm{Zr}_{\text {sat }}$ and $\mathrm{T}_{\mathrm{Zr}}$ (Figure 6.2). This phenomenon has been rationalized by Miller et 
al. (2003) to be caused by cumulate crystals (other than zircon) leading to a more mafic composition than the coexisting melt, which in turn creates higher $\mathrm{M}$ values and lower $\mathrm{T}$ Zr. As this sample is a granodioritic charnockite with a lower $\mathrm{Zr}$ ppm, the overall composition is more mafic (58.18 wt. \% $\mathrm{SiO}_{2}$ vs. 61.85 wt. \% and 66.97 wt. \%, Appendices A and C) than other included samples and could be a reason for the large discrepancy. In all cases, $\mathrm{T}_{\mathrm{zr}}$ is lower than the rhyolite-MELTS modeled temperature, which is consistent with $\mathrm{T}_{\mathrm{zr}}$ being a minimum estimate of magma temperature. Sample NJ 15-1 shows an abundance of alkali feldspar at the modeled temperature (Figure 6.1) and this is supported with the presence of microperthite in thin section (Figure 4.3b).

There are limitations involved when using the rhyolite-MELTS modeling technique to estimate zircon saturation temperatures. Firstly, hydrous phases such as biotite and hornblende are not well modeled and therefore the program perhaps introduces a degree of inaccuracy for intermediate compositions like samples VA 15-1 and VA 15-2. Secondly, many bulk-rock compositions of plutonic rocks are not initial melt compositions (Miller et al., 2003). Both simulations were performed keeping pressure static at $500 \mathrm{MPa}$ as the depth of emplacement and crystallization is unknown. Though previous research shows that zircon solubility is unaffected by pressure, zircon solubility may be affected by dry $\left(<\sim 1.5\right.$ wt. $\left.\% \mathrm{H}_{2} \mathrm{O}\right)$ peralkaline melt compositions (Watson and Harrison, 1983), and the samples selected for this study are assumed to be relatively anhydrous. We assume that the models are not overestimating zircon saturation temperatures because all samples lack xenocrystic inherited components as demonstrated in Chapter V by CL imaging and U-Pb geochronology. 

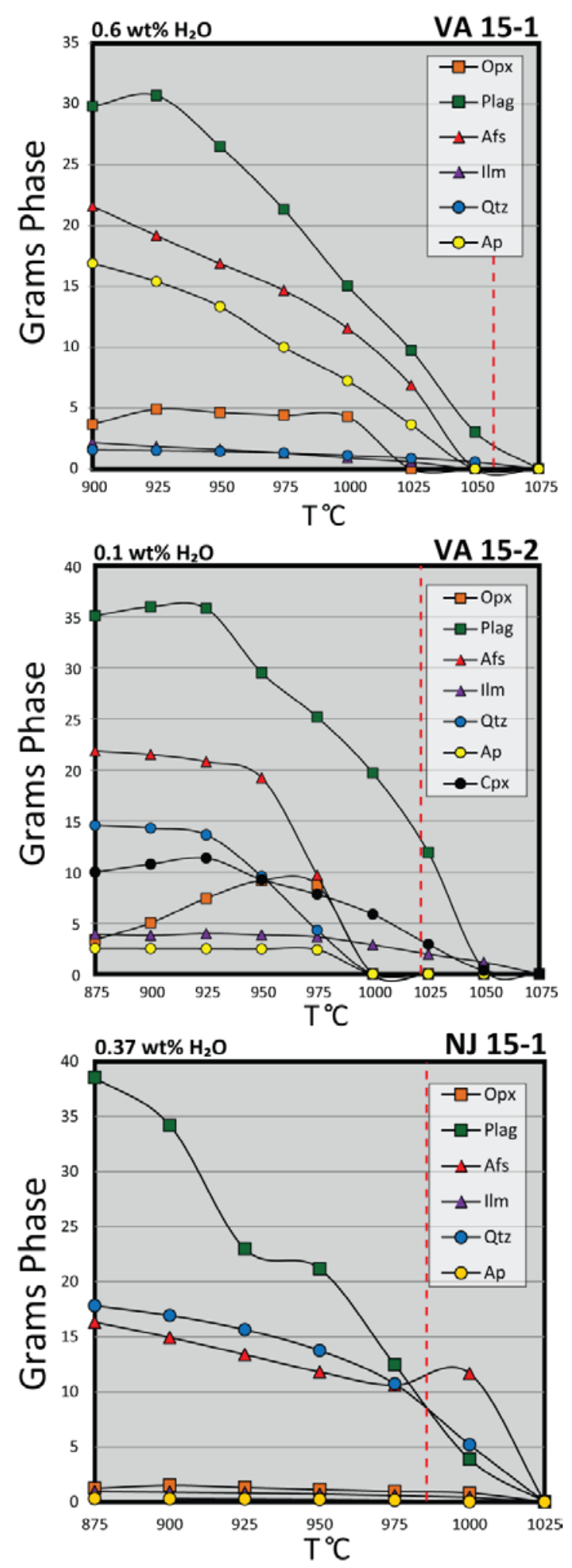

Figure 6.1: Sequence of melt crystallization output from rhyolite-MELTS at bulk-rock LOI $\mathrm{H}_{2} \mathrm{O}$ conditions and $25{ }^{\circ} \mathrm{C}$ temperature increments. Red dashed line indicates modeled temperature $\mathrm{Zr}_{\text {sat. }}$. 
VA 15-1
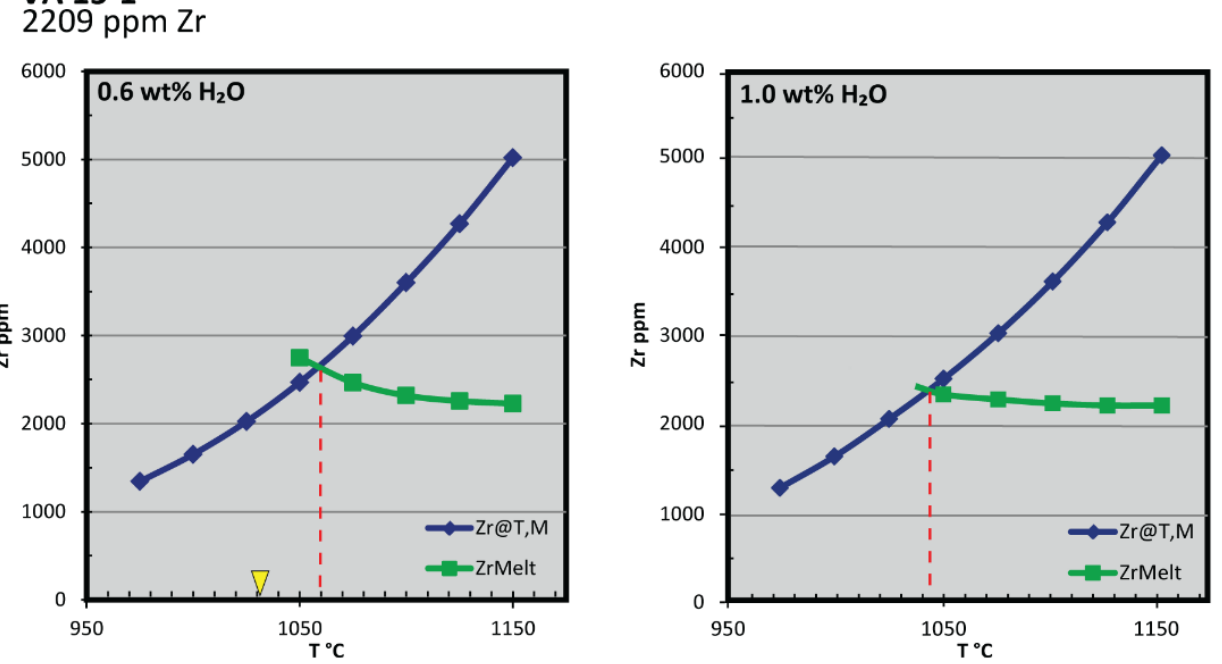

VA 15-2
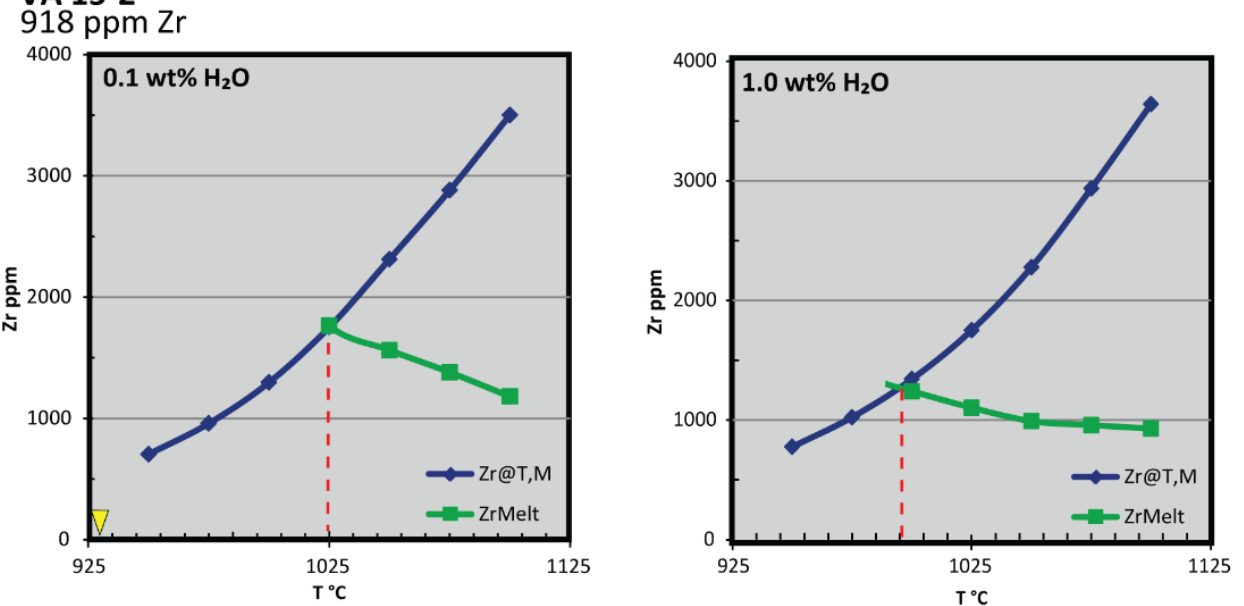

NJ 15-1
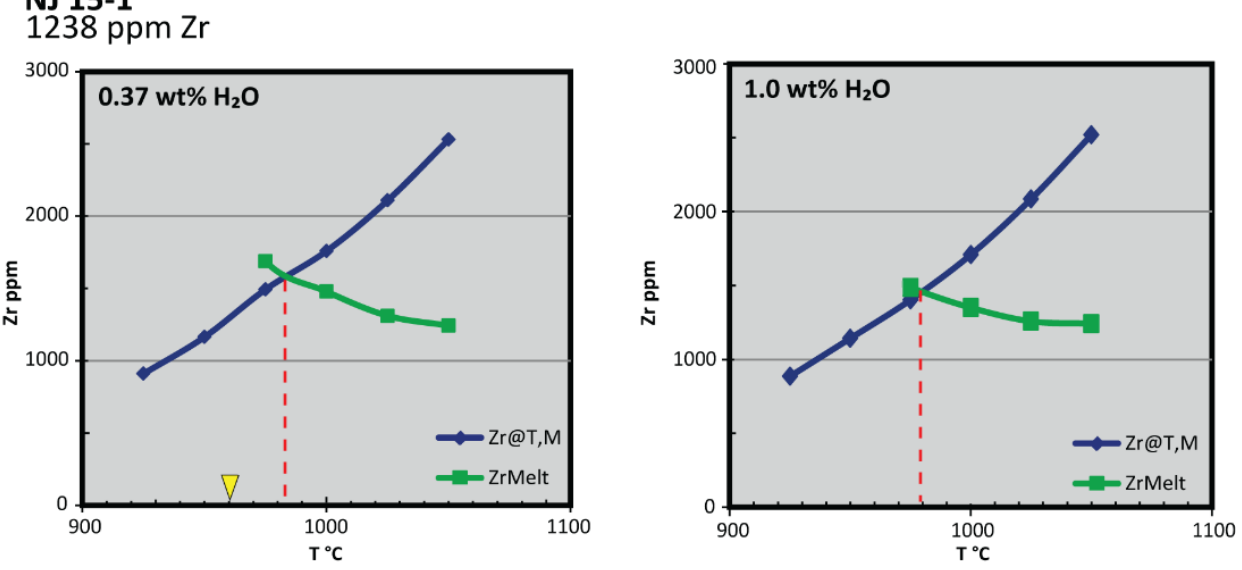

Figure 6.2: Results of crystallization modeling from rhyolite-MELTS. Blue line and diamonds show decrease in $\mathrm{Zr}$ concentration calculated from $\mathrm{M}$ at each temperature (T). Green line and squares show increasing Zr concentration in residual melt, initial conditions from bulk-rock composition. Vertical dashed line represents intersection of two curves: the temperature at which $\mathrm{Zr}_{\text {sat }}$ is reached. Yellow arrow is bulk-rock $\mathrm{T}_{\mathrm{Zr}}$. Note: VA $15-2 \mathrm{~T}_{\mathrm{Zr}}$ is $898{ }^{\circ} \mathrm{C}$ but is placed at 925 ${ }^{\circ} \mathrm{C}$ for visual comparison. 


\section{CHAPTER VII. RESULTS OF TI-IN-ZIRCON THERMOMETRY}

Zircons from all three samples (VA 15-1, VA 15-2, NJ 15-1) were analyzed for Ti and other trace elements (Fe, Y, La, Ce, Nd, Sm, Eu, Gd, Dy, Er, Yb, Hf, U, Th) in situ at Stanford University’s SHRIMP-RG ion microprobe lab in order to obtain high mass resolution concentrations (Appendix D). Emphasis was placed on Ti concentration in order to evaluate Ti-in-zircon thermometry. Details of analytical methods and instrument configuration are presented in Chapter III. Measured Ti concentrations are estimated to be precise to $\pm 0.1 \mathrm{ppm}$ based on repeated measurement of the Ti standard. Trace element concentrations were calculated relative to MADDER, a well-characterized, homogeneous Madagascar Green in-house zircon standard whose values are calibrated relative to 91500 (Wiedenbeck et al., 1995, 2004) for all elements except Ti. Ti concentrations were calculated relative to zircon standard SL13 using $\mathrm{Ti}=6.14 \pm 0.01$ ppm (Hiess et al., 2008) for comparison with sample Ti-in-zircon values. Our analyses in this study return $\mathrm{Ti}=6.26 \pm 0.09$ for SL13 (Appendix D). Standards were analyzed at the beginning of initial setup and mounted on a separate mount. All trace element measurements have been normalized to ${ }^{30} \mathrm{Si}^{+}$. Elemental ratios were calculated using SQUID2.51, a Microsoft Excel add-in program (Ludwig, 2009).

Estimates of crystallization temperatures were calculated using Ferry and Watson’s (2007) calibration of the Ti-in-zircon thermometer:

$$
\log (\text { ppm Ti-in-zircon })=(5.711 \pm 0.0772)-((4800 \pm 86) / \mathrm{T})-\log \mathrm{a}_{\mathrm{SiO}_{2}}+\log \mathrm{a}_{\mathrm{TiO}_{2}}
$$

where $\mathrm{T}$ is in Kelvin but will be reported hereafter as Celsius. Rearranging and solving for $\mathrm{T}$ (in ${ }^{\circ} \mathrm{C}$ ) yields the expression:

$$
\mathrm{T}\left({ }^{\circ} \mathrm{C}\right)=\left(-4800 \pm 86 /\left(\left(\log (\mathrm{ppm} \text { Ti-in-zircon })-(5.711 \pm 0.0772)+\log \mathrm{a}_{\mathrm{SiO}_{2}}-\log \mathrm{a}_{\mathrm{TiO}_{2}}\right)\right)-273\right.
$$


This method requires accurate Ti measurements and well constrained activities of titania and silica in the melt, $\mathrm{a}_{\mathrm{TiO}_{2}}$ and $\mathrm{aSiO}_{2}$, respectively. Titania activity is dependent on degree of rutile saturation and silica activity is dependent on quartz saturation. Quartz is present in all samples, and therefore, by definition, $\mathrm{aSiO}_{2}=1.0$ for temperature calculations. Rutile $\left(\mathrm{TiO}_{2}\right)$ is not present in the samples for this study but both ilmenite and titanite are found as accessory phases, so we assume that $\mathrm{a}_{\mathrm{TiO}_{2}}=<1.0$ during crystallization of zircon and use 0.7 for calculations, as recommended by Ghiorso and Gualda, (2013). Sample NJ 151 had an abundance of titanite, and when $\mathrm{a}_{\mathrm{TiO}_{2}}$ was increased to 0.9 with $\mathrm{asiO}_{2}=1.0$, temperature estimates for all samples decreased by $26-29^{\circ} \mathrm{C}$ on average.

\section{Blue Ridge Province}

Zircon in orthogneiss sample VA 15-1 contains a range of Ti concentrations from 7 - 86 ppm (Figure 7.1) and estimated temperatures range from $749-1053^{\circ} \mathrm{C}$. Inner growth zones (apparent “cores”) range from 7 - 86 ppm Ti. Outer growth zones (apparent “rims”) range from $12-40$ ppm Ti.

Granodioritic charnockite sample VA 15-2 contains a range of Ti concentrations from 7 - 36 ppm (Figure 7.1). This collection is skewed by the large population of values less than 20 ppm. Estimated temperatures range from $750-928^{\circ} \mathrm{C}$. Inner growth zones range from 7 - $36 \mathrm{ppm} \mathrm{Ti}$, and outer growth zones range from 8 - $27 \mathrm{ppm} \mathrm{Ti}$.

\section{New Jersey - Hudson Highlands}

Granite sample NJ 15-1 contains a range of Ti concentrations from 2 - 38 ppm (Figure 7.1) and estimated temperatures range from $656-935^{\circ} \mathrm{C}$. Inner growth zones range from 4 - $38 \mathrm{ppm} \mathrm{Ti}$, and outer growth zones range from 2 - 14 ppm Ti. 


\section{Discussion}

Ti-in-zircon concentrations are highly dependent on temperature in experimental studies (Watson and Harrison, 2005; Watson et al., 2006; Ferry and Watson, 2007) and yield a precision of $\pm 5^{\circ} \mathrm{C}$, though the accuracy of this geothermometer has geologic limitations with regard to natural zircons and their petrologic context (Fu et al., 2008). This study was designed to further evaluate accuracy and geologic limitations of the zircon thermometers. For the samples selected, there remains a degree of Ti variability within individual grains, especially when including both “core” and "rim” values into an average temperature and concentration.

In interpretation of the Ti measurements, and inter- and intragrain (core vs. rim measurements) variations in Ti concentration for each sample, it is important to take into consideration the likelihood that zircon crystallizes over a temperature interval between the liquidus and solidus (the “zircon crystallization spectrum”: Harrison et al., 2007) (Figure 7.2) as the magmatic conditions evolve. High-Zr $\left(850-1050{ }^{\circ} \mathrm{C}\right.$, hot) granitoids should yield zircon crystallization spectra that encompass a higher range of temperatures than spectra for low-Zr (650 - $750{ }^{\circ} \mathrm{C}$, cold) granitoids (Miller et al., 2003; Moecher et al., 2014).

Sample VA 15-1 has a high degree of zircon homogeneity, in that the grains do not have rim overgrowths, or the rims are very thin, and are proposed to be metamorphic (Figure 7.2). Zircons from sample VA 15-2 have a much different style of growth zonation, although two distinct types of zircon are evident in CL, both of which are thick enough to analyze (Figure 7.2). Zircons from sample NJ 15-1 have very dark, thick rim overgrowths as well as fully homogenous grains (Figure 7.2). 
Variations in CL zoning in zircon relate to variations in trace element composition of grains that develop during crystallization, and are controlled by the $\mathrm{K}_{\mathrm{D}}$ between melt and zircon as melt composition and temperature evolve (Hanchar and Miller, 1993). Intragrain variation in CL (apparent cores vs. rims in CL) may indicate partial mixing or assimilation with a mafic component, especially in sample VA 15-2 where grains display a large degree of heterogeneity (Figure 7.2) (Padilla et al., 2016). This sample also has the greatest variability in trace element enrichment with regard to intragrain REE scatter (Figure 7.3). Note that all samples are depleted in Eu, with VA 15-1 and VA 15-2 more than NJ 15-1, possibly a product of their greenschist metamorphic overprinting. Ce anomalies are positive and Eu-negative, and these are common anomaly patterns in igneous zircons, but a negative Eu anomaly is not expected for crustal zircon (Hoskin and Schaltegger, 2003). This paradox is explained by plagioclase fractionation which depletes Eu before or during zircon crystallization (Hoskin and Schaltegger, 2003). Plagioclase is a crystallizing phase at modeled temperature from rhyolite-MELTS (Figure 6.1). Variability in Ti-in-zircon concentrations does not correlate with CL zoning. For example, VA 15-1 cores average $\mathrm{Ti}=31 \mathrm{ppm}$, where rims average $\mathrm{Ti}=22 \mathrm{ppm} . \mathrm{VA} 15-2$ Ti averages are equal at $15 \mathrm{ppm}$. We see the greatest difference in Ti concentration between cores and rims in NJ 15-1 (17 ppm vs. 7 ppm) paired with extreme contrast in CL color. CL contrast is not definitively correlated with Ti concentration, though this cannot be fully ruled out and further clarification of relationships is needed as REE enrichment is seemingly linked to CL color (Figure 7.3). Fu et al., (2008) have reported lower Ti concentrations in zircon than predicted for natural zircons. 

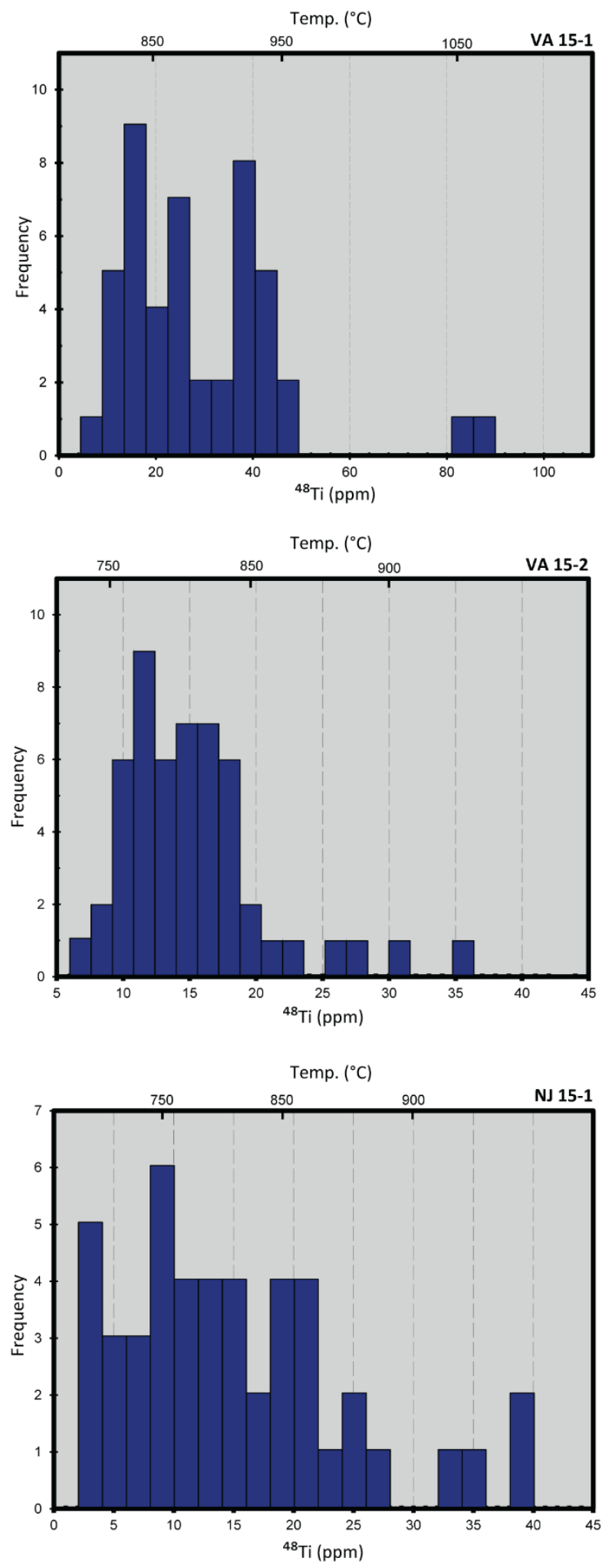

Figure 7.1: Histogram of Ti-in-zircon concentration for all analyzed spots. VA 15-1 ranges from 7-86 ppm. VA 15-2 ranges from 7-36 ppm. NJ 15-1 ranges from 2-38 ppm. 


\section{VA $15-1$}

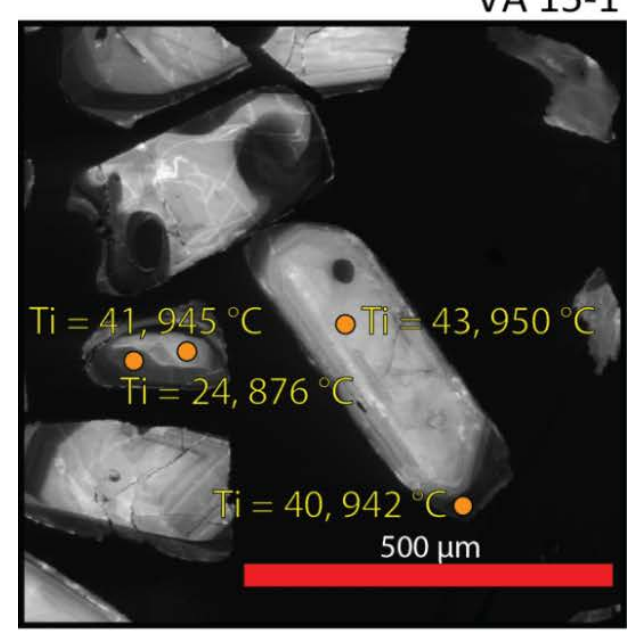

VA $15-2$

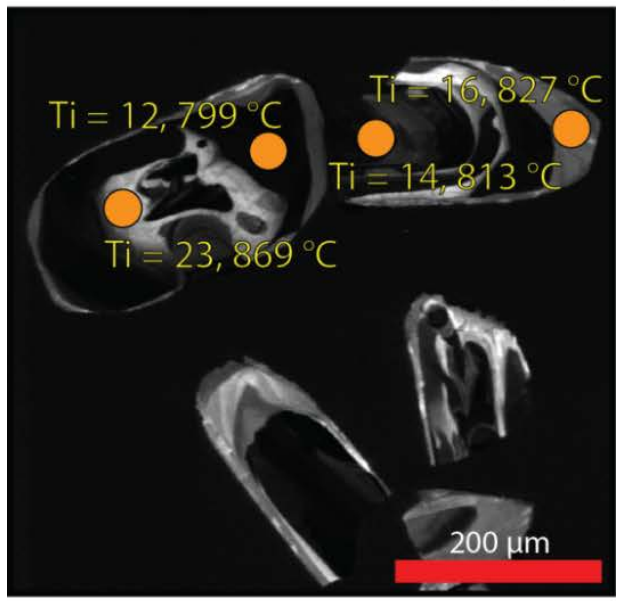

NJ $15-1$

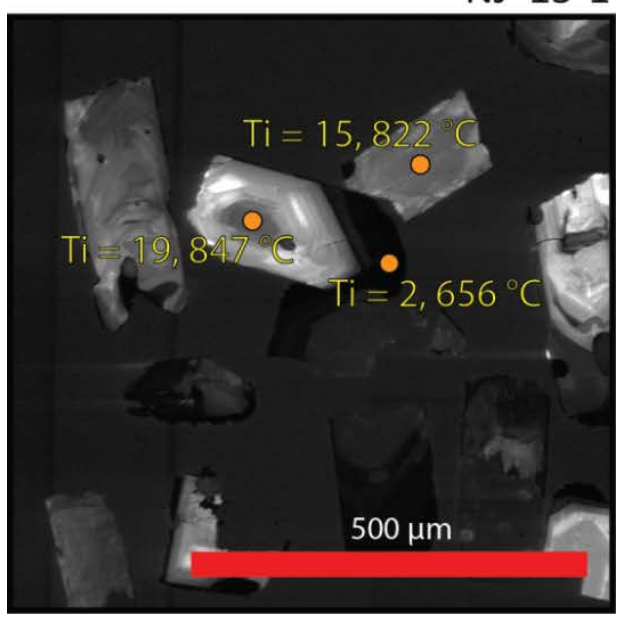

Figure 7.2: SEM images of selected SHRIMP-RG analysis spots. Images show differences between zircon zonation, CL color variations, and their corresponding Ti-in-zircon concentrations and associated temperature estimations. 

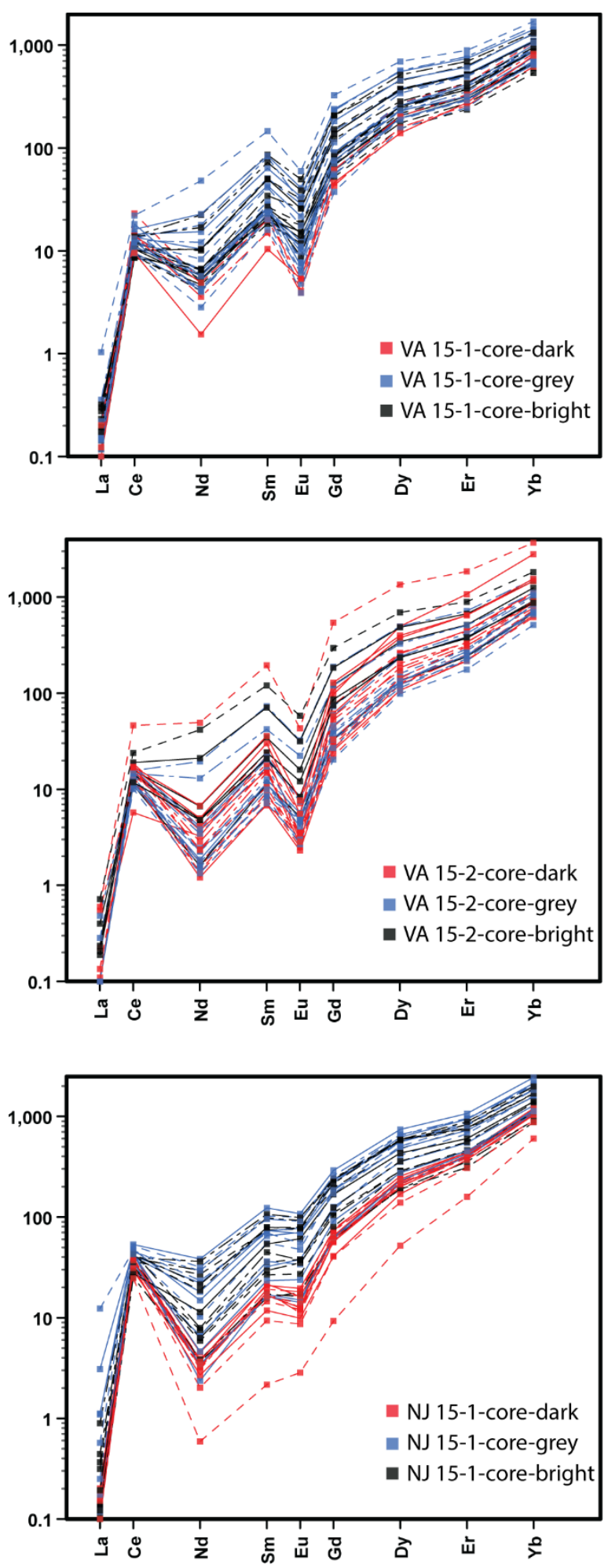

Figure 7.3: REE plot normalized to CI chondrite (McDonough and Sun, 1995). VA 15-1 displays dark CL at lower concentrations in trace elements. VA 15-2 displays variability in trace element with regard to CL color (more scatter). NJ 15-1 displays a stark separation of CL color and trace elements, again with dark colors having lower levels of REE concentration. 


\section{CHAPTER VIII. CONCLUSIONS}

Three granitoids collected from the Blue Ridge province and the New Jersey Hudson Highlands were examined using U-Pb geochronology, whole-rock geochemistry, zircon saturation thermometry, rhyolite-MELTS quantitative modeling, and Ti-in-zircon trace element analyses to evaluate the use of zirconium and zircon as granite geothermometers in Grenvillian mid-crustal magmas. Calculating geologically meaningful temperatures for felsic magmatic systems is a challenging task, and this thesis provides new data that further explain the difficulties and limitations when determining initial crystallization temperatures and conditions using zircon geothermometers, which are considered among the most reliable methods available for doing so (Watson and Harrison, 1983; Miller et al., 2003; Ferry and Watson, 2007; Harrison et al., 2007). Sample VA 15-1, an orthogneiss from the Lovingston massif in the Blue Ridge province, has a calculated zircon saturation temperature $\left(\mathrm{T}_{\mathrm{zr}}\right)$ of $1032{ }^{\circ} \mathrm{C}$ when using Watson and Harrison's (1983) bulk-rock zircon saturation thermometer. The rhyoliteMELTS modeled temperature for onset of zircon crystallization is estimated at $1060{ }^{\circ} \mathrm{C}$, exceeding $\mathrm{T}_{\mathrm{zr}}$ by approximately $30^{\circ} \mathrm{C}$. The highest Ti-in-zircon temperature range (749 $1053^{\circ} \mathrm{C}$ ) agrees well with the rhyolite-MELTS temperature (Figure 8.1).

Sample VA 15-2, a granodioritic charnockite from the Pedlar massif in the Blue Ridge province, has a $\mathrm{T}_{\mathrm{zr}}$ of $898{ }^{\circ} \mathrm{C}$. The rhyolite-MELTS modeled temperature greatly exceeds this value by approximately $130{ }^{\circ} \mathrm{C}$, and is estimated at $1024^{\circ} \mathrm{C}$. The Ti-inzircon temperatures range from $750-928{ }^{\circ} \mathrm{C}$ and are more comparable to the $\mathrm{T}_{\mathrm{zr}}$ value than with rhyolite-MELTS (Figure 8.1). 
Sample NJ 15-1, a granite from the New Jersey - Hudson Highlands, has a $T_{z r}$ of $960^{\circ} \mathrm{C}$. The rhyolite-MELTS modeled temperature is similar, estimated at $983^{\circ} \mathrm{C}$. The Ti-in-zircon apparent temperatures range from $656-935{ }^{\circ} \mathrm{C}$ and agree well with our rhyolite-MELTS and $\mathrm{T}_{\text {zr }}$ geothermometers (Figure 8.1). Furthermore, previous data from Moecher et al., (2014), show that for two samples (VA 12-1 and VA 12-2, an orthogneiss and charnockite from the Virginia Blue Ridge, respectively), modeled results agree with the orthogneiss and we again see a discrepancy in temperatures for the charnockite.

The sample with the least variability between each geothermometer is NJ 15-1 $\left(\sim 159{ }^{\circ} \mathrm{C}\right)$. This is likely due to the lack of greenschist metamorphic overprinting that has occurred in both VA 15-1 and VA 15-2. VA 15-2 has the lowest Zr ppm (918) and the greatest difference in temperature estimates $\left(\sim 204^{\circ} \mathrm{C}\right)$. In all cases, rhyolite-MELTS predicts zircon saturation to begin at the highest Ti-in-zircon temperature (Figure 8.1). As previously mentioned in Chapter VI, rhyolite-MELTS cannot accurately account for hydrous phases such as hornblende and biotite, and this may affect crystallization sequences. The two samples with the highest bulk rock Zr concentration (VA 15-1 and NJ 15-1) have the least difference in rhyolite-MELTS and $T_{z r}$ temperatures. Both samples also contain a substantial amount of homogenous, recrystallized zircon grains that lack, or have very thin, rims in CL. The Ti-in-zircon temperatures range on the lowest end from $656-750^{\circ} \mathrm{C}$ and on the highest end from $928-1053{ }^{\circ} \mathrm{C}$. These values are consistently among the highest apparent temperatures previously reported for felsic to intermediate rocks $\left(653-758^{\circ} \mathrm{C}\right)$ (Fu et al., 2008).

The data show that the agreement between two widely used and well calibrated zircon geothermometers ( $\mathrm{T}_{\mathrm{zr}}$ and Ti-in-zircon) lends confidence to the interpretation that 
they are yielding geologically meaningful temperature results. Though there are discrepancies between each temperature estimate, they still qualify as hot (Miller et al., 2003) and thus are ancillary supporting evidence for the hot Grenville granite hypothesis (Moecher et al., 2014). In the latter study, crystallization of dry, hot Grenville granites with varying $\mathrm{Zr}$ concentrations began to precipitate zircon near the liquidus at $~ 1050$ $1125^{\circ} \mathrm{C}$ when modeled using rhyolite-MELTS. Ti-in-zircon thermometry yielded temperatures that ranged from $\sim 781-1035^{\circ} \mathrm{C}$ and $\mathrm{T}_{\mathrm{zr}}$ calculations yielded temperatures ranging from $\sim 835-998^{\circ} \mathrm{C}$. The data in this thesis are similar to the Moecher et al., (2014), study in that the Ti-in-zircon temperatures are among the highest reported, though they have a larger range $\left(\sim 656-1053{ }^{\circ} \mathrm{C}\right)$. $\mathrm{T}_{\mathrm{zr}}$ temperatures are hotter $\left(\sim 960-1032{ }^{\circ} \mathrm{C}\right)$ and rhyolite-MELTS modeled temperatures are cooler $\left(\sim 983-1060{ }^{\circ} \mathrm{C}\right)$.

Although mineral grains crystallizing form a magma (e.g., plagioclase, quartz, zircon) must crystallize over some time interval between liquidus and solidus (i.e., not all grains of any mineral crystallized at the same instance in time), zircon from ca. $1 \mathrm{Ga}$ plutonic systems cannot be used to resolve the time of crystallization of individual zircon grains, because we cannot resolve with sufficient precision via SIMS, SHRIMP-RG, or LA-ICP-MS, differences in $\mathrm{U}$ and $\mathrm{Pb}$ isotope ratios. Since Ti concentrations can be measured with much higher precision ( $\pm 0.1 \mathrm{ppm})$, Ti-in-zircon can be used not only for calculating temperature at the instant a particular zircon grain crystallized, but to also track the crystallization of the bulk of the zircon grains in a granite. The highest Ti concentrations for each sample are consistent with a high temperature (near liquidus) for the onset of zircon saturation. However, for all samples the majority of Ti concentrations indicate the bulk of the zircon crystallized at temperatures lower than the liquidus (Figure 
8.1). It may be that bulk melt $\mathrm{Zr}$ contents became critically undersaturated, at which point the rate of zircon crystallization increased substantially.

Quantitative tectonic evolution models for the western margin of the Grenville orogeny in Canada do not take into account any crustal heat generation caused by mantle or magmatic influx, but rather account for heating by stacking of multiple crustal-scale thrust zones (Jamieson et al., 2010). Equivalent eastern margin Grenvillian rocks in the Appalachians cannot be explained by a similar model, as the basement granitoids display weaker degrees of deformation and are exceptionally Zr-rich (Tollo et al., 2004a; Moecher and Samson, 2006; Burton and Southworth, 2010). Because zircon solubility is directly related to temperature, an interpretation that allows for increased crustal temperatures is required for production of granitoids with temperatures ranging from $\sim 900$ to $\sim 1000{ }^{\circ} \mathrm{C}$. Extensive melting of continental crust may be explained by ultrahightemperature (UHT) magmatic regimes analogous to the granulite province of southern India where individual terranes were accreted during the Proterozoic (Brown and Raith, 1996). Pressure and temperature conditions in this region suggest temperatures on the order of $900-1000{ }^{\circ} \mathrm{C}$ at $12 \mathrm{kbar}$ (Brown and Raith, 1996). Field settings indicate that these high-grade, intensely deformed granulites occured in overthickened crust, and the high temperatures may have increased magmatic events in the area (Brown and Raith, 1996).

Previous research shows that in lower crustal zones affected by lithospheric delamination or basaltic underplating at high temperatures ranging from $1000-1200{ }^{\circ} \mathrm{C}$ (Annen et al., 2006), the melt may become undersaturated in $\mathrm{Zr}$ and thus zircon. This scenario would result in low $\mathrm{T}_{\mathrm{zr}}$ temperatures even if high melting temperatures were 
involved, because the bulk-rock composition would not directly correlate with initial melt conditions where zircon crystallization began. The granitoids in this study are primarily A-type, and they are likely to be created from mantle-derived intermediate magmas (Bonin, 2007). Smithies et al., (2011), propose a model using UHT underplating to explain the Mesoproterozoic Musgrave Orogeny in Australia that may indicate a similar situation for the Grenville Orogeny: granitoids, including charnockites, were emplaced under high temperatures $\left(\geq 1000^{\circ} \mathrm{C}\right)$ and resulted from under- and intraplated mafic magmas that provided a constant supply of heat to melt the available felsic crust. Smithies et al., (2011), proposed that mantle plumes would not be consistent with a long, prolonged orogeny, such as the Grenville.

Ultrahigh-temperature metamorphism is a thermal extreme when compared to typical regional metamorphism. Thermal models from Kelsey and Hand, (2014), indicate that regional UHT metamorphic regimes can be created when subduction zones (for example, during a collisional orogeny) occur simultaneously with elevated rates of radiogenic heat generation in the crust. This study also compiled Ti-in-zircon thermometry data from multiple sources and found that there are two distinct temperature peaks at $\sim 810^{\circ} \mathrm{C}$ and $\sim 925{ }^{\circ} \mathrm{C}$, and a handful of analyses over $1000{ }^{\circ} \mathrm{C}$, with a dry granitic liquidus (the maximum temperature limit) at $1140{ }^{\circ} \mathrm{C}$ and $8 \mathrm{kbar}$. The average temperatures in our investigation range from approximately $900{ }^{\circ} \mathrm{C}$ to $1000{ }^{\circ} \mathrm{C}$ and fall directly in line with values compiled by Kelsey and Hand, (2014), indicating a possible connection between UHT metamorphism, crustal melting, and crustal metamorphism during periods of the Grenville orogeny. 


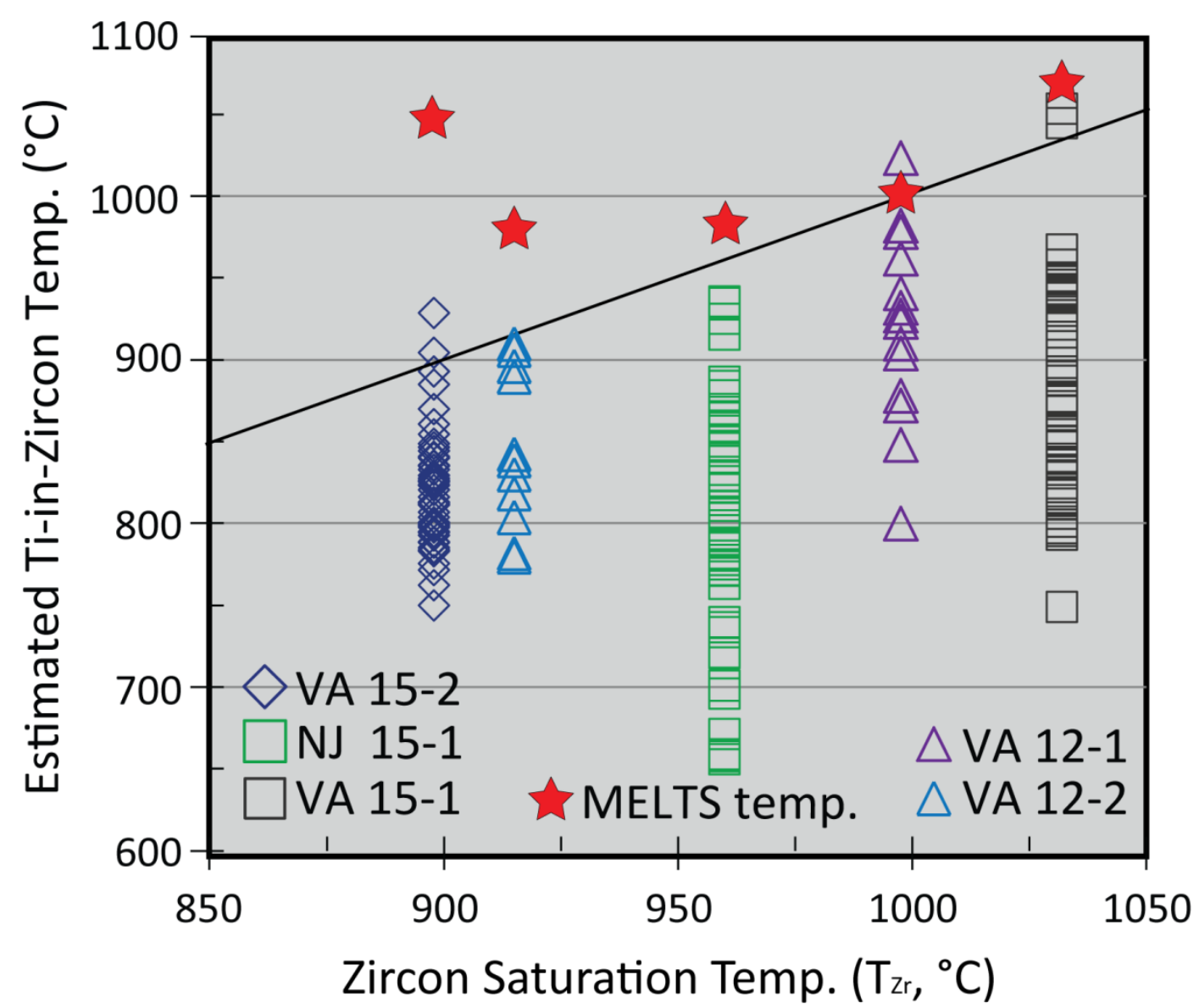

Figure 8.1: Estimated whole-rock zircon saturation temperatures $\left(\mathrm{T}_{\mathrm{zr}}\right)$ calculated using the Watson and Harrison (1983) thermometer, plotted against estimated Ti-in-zircon (Ferry and Watson, 2007) crystallization temperatures. Large, filled symbols represent mean (+ 1 standard deviation) Ti-in-zircon temperatures for each sample. Red stars represent rhyolite-MELTS zircon crystallization temperature for each sample. Solid line indicates a ratio of 1 . Note how both charnockites have rhyolite-MELTS modeled temperature discrepancies (Figure after Padilla et al., 2016). 
APPENDICES 


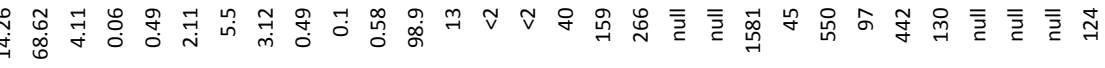

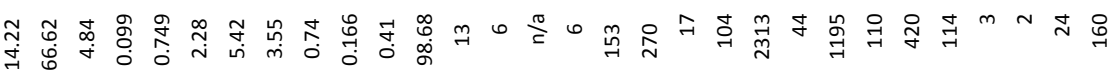

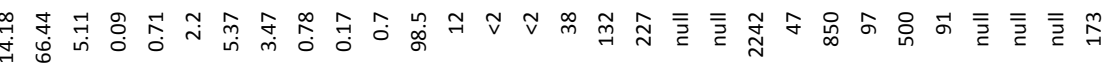

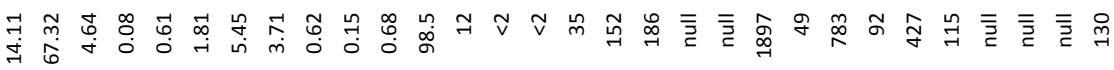

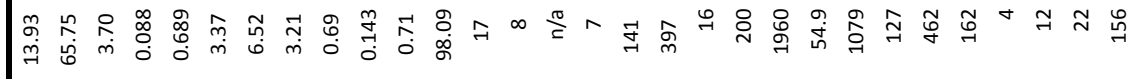

侨

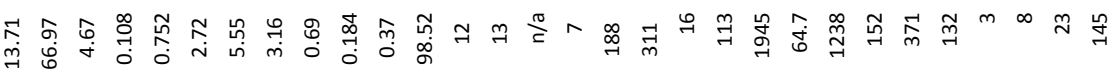
虽 胥

舟 莳

员 糹

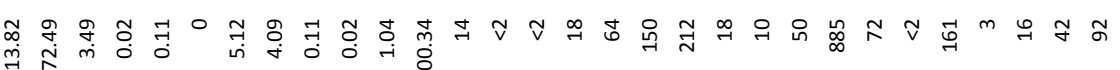

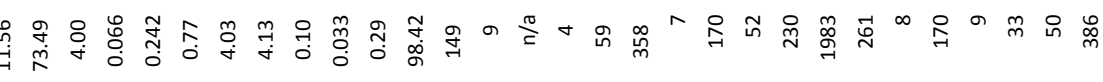

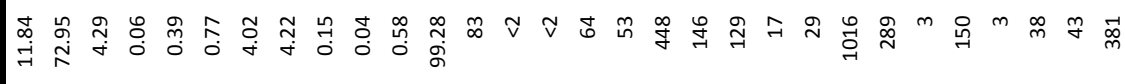

舟

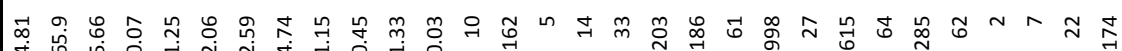
章

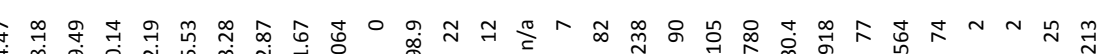
$+\frac{1}{2}+\frac{1}{2}$

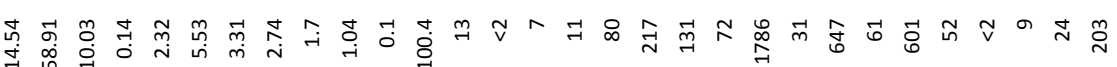

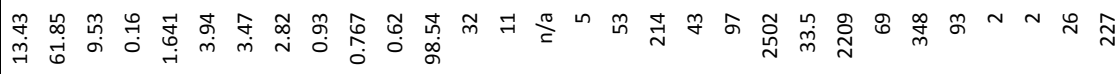

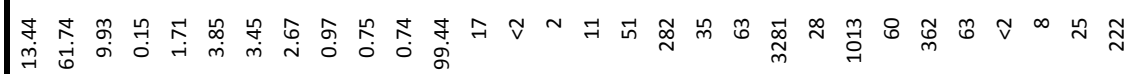

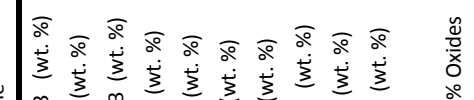




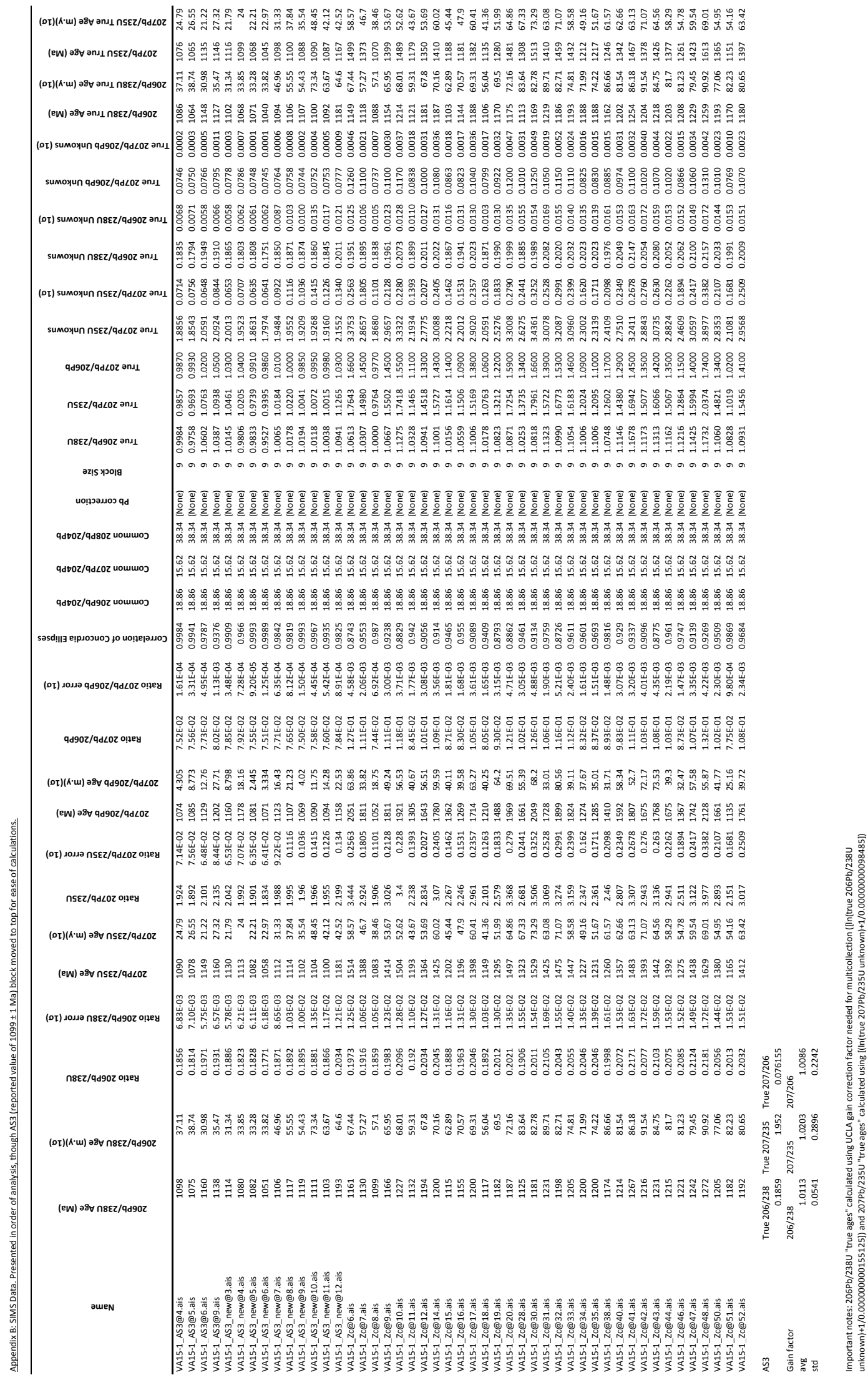




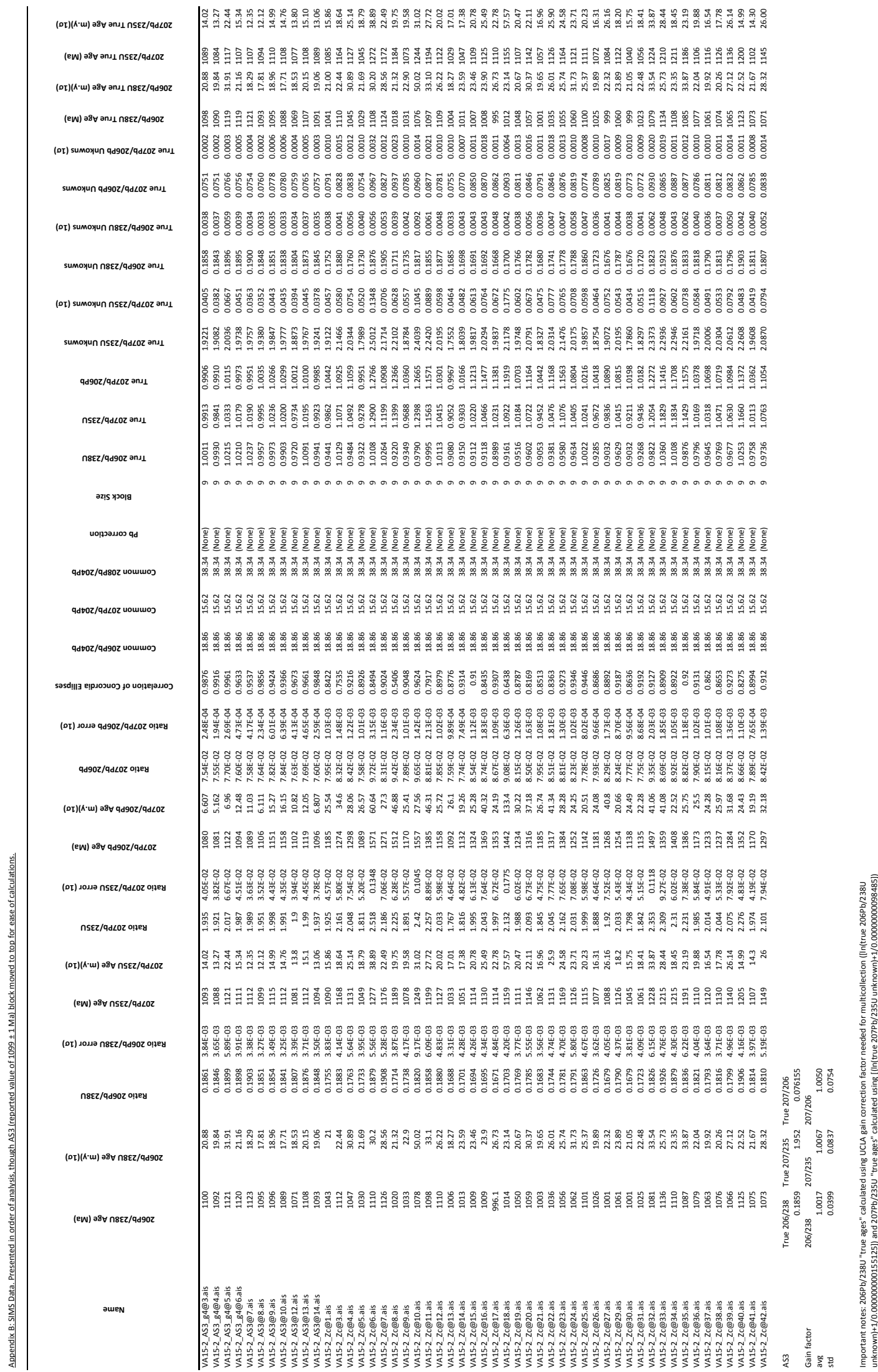




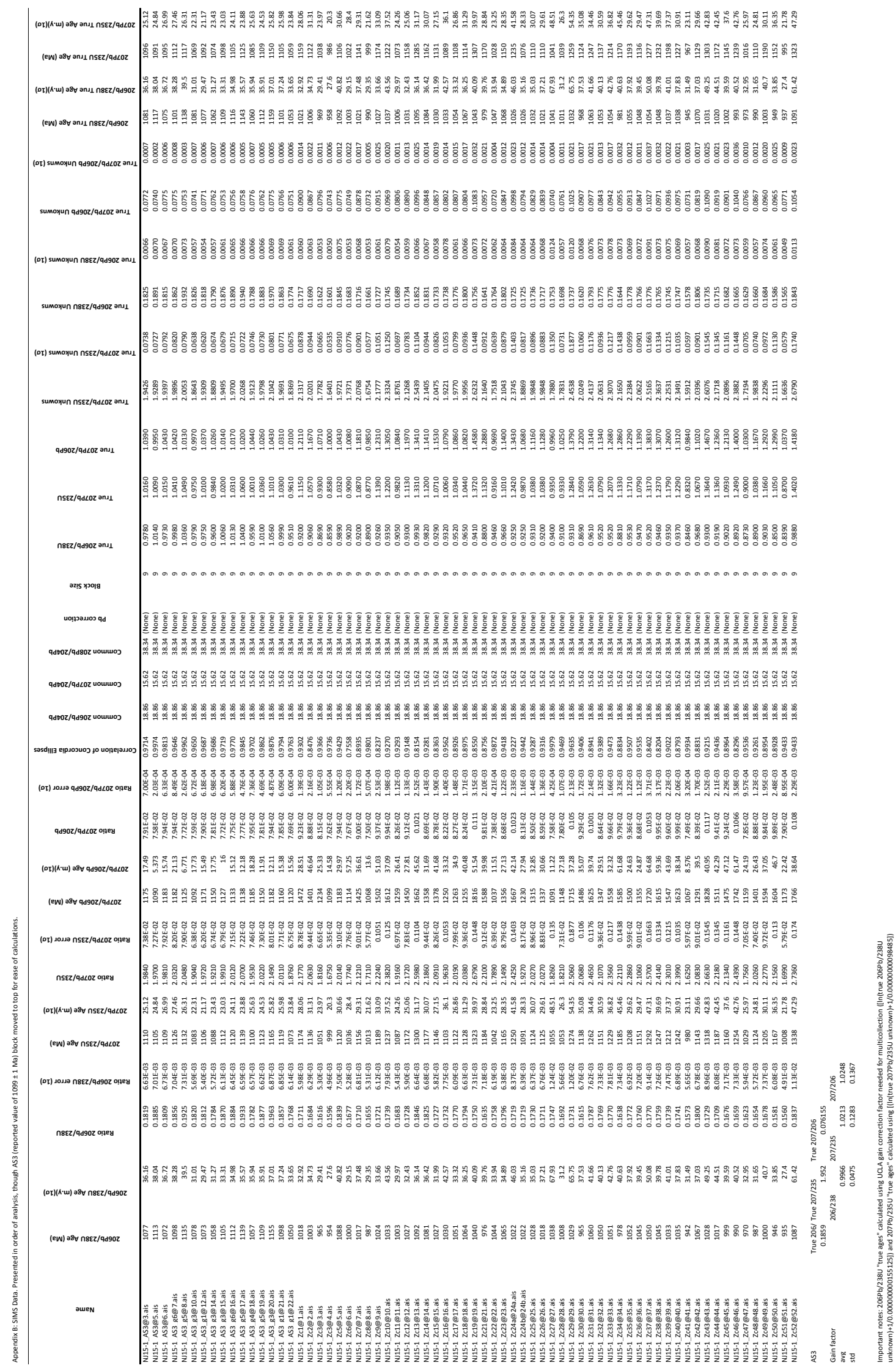


ธัญ ฮ

$+1 \stackrel{\pi}{\frac{\pi}{\pi}}$

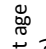

$+1 \stackrel{\sqrt{0}}{\stackrel{7}{2}}$

* *

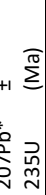

$+1 \stackrel{\frac{\pi}{5}}{5}$

莒

홓ㅎㅎㅇ

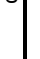

+1 ब

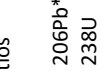

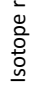
$>$ 응

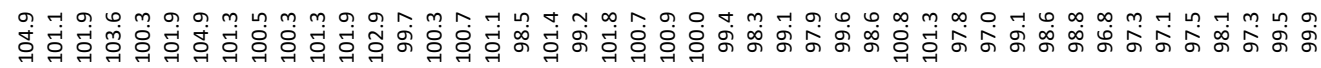

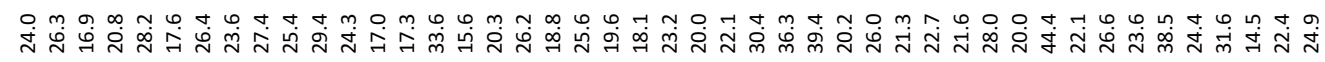

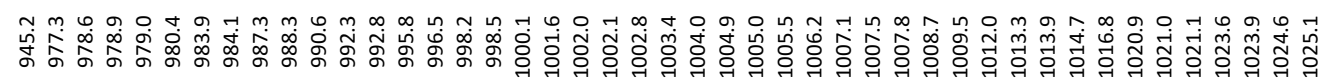

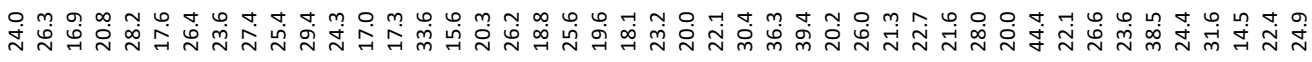

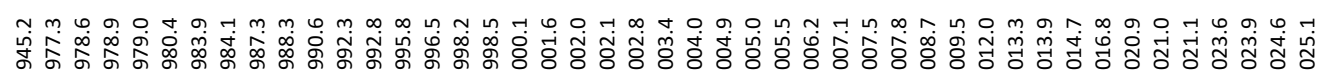

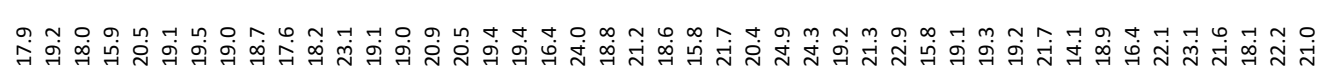

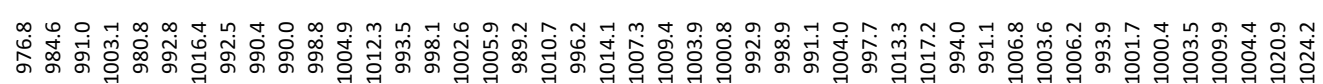

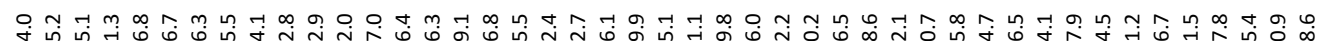

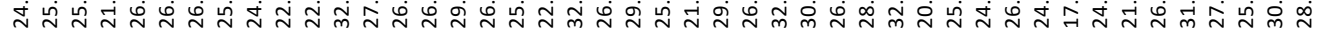

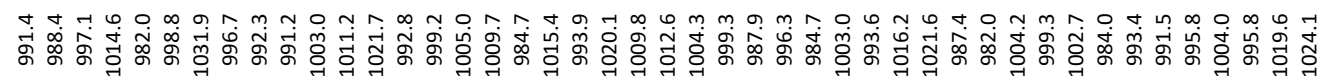

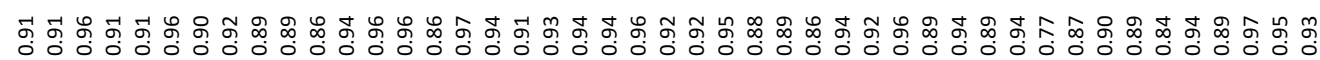

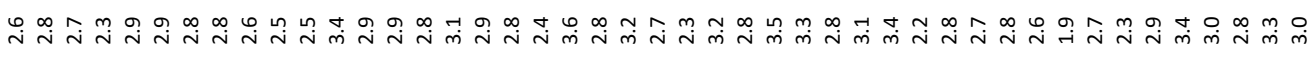

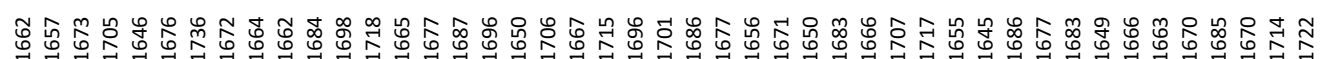

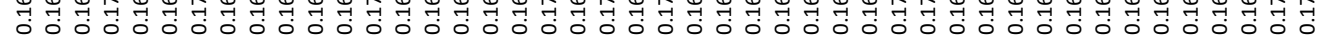

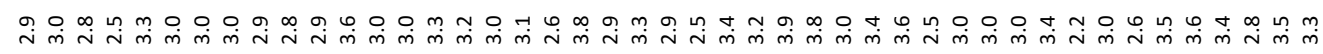

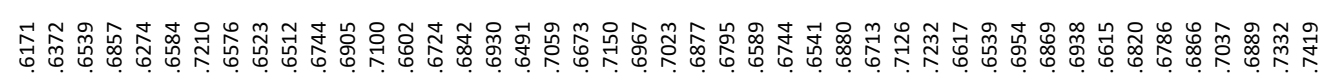
传

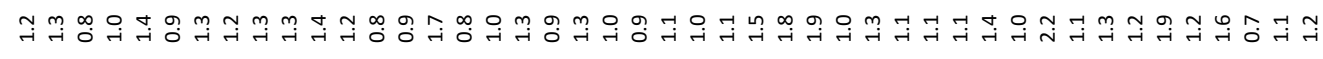

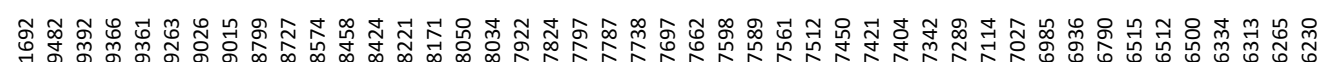

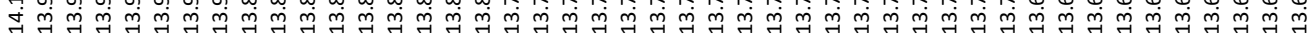

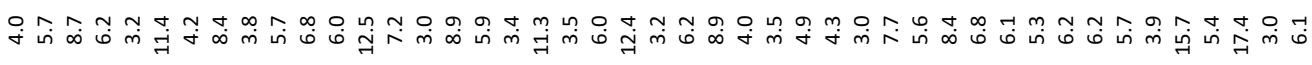

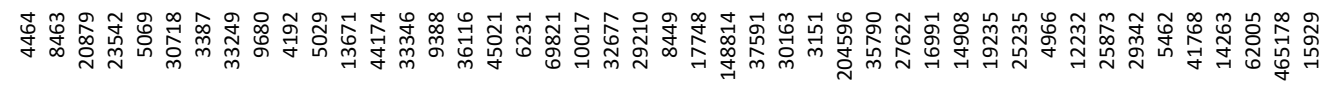

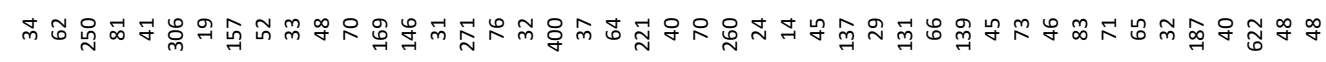

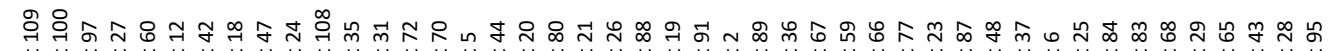

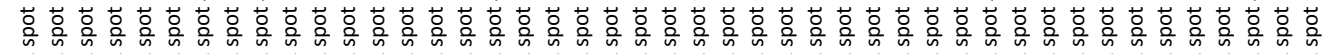

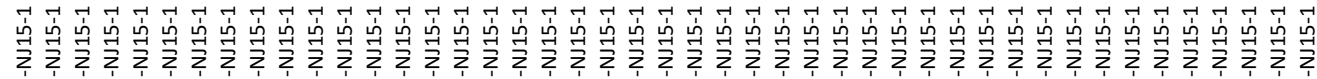




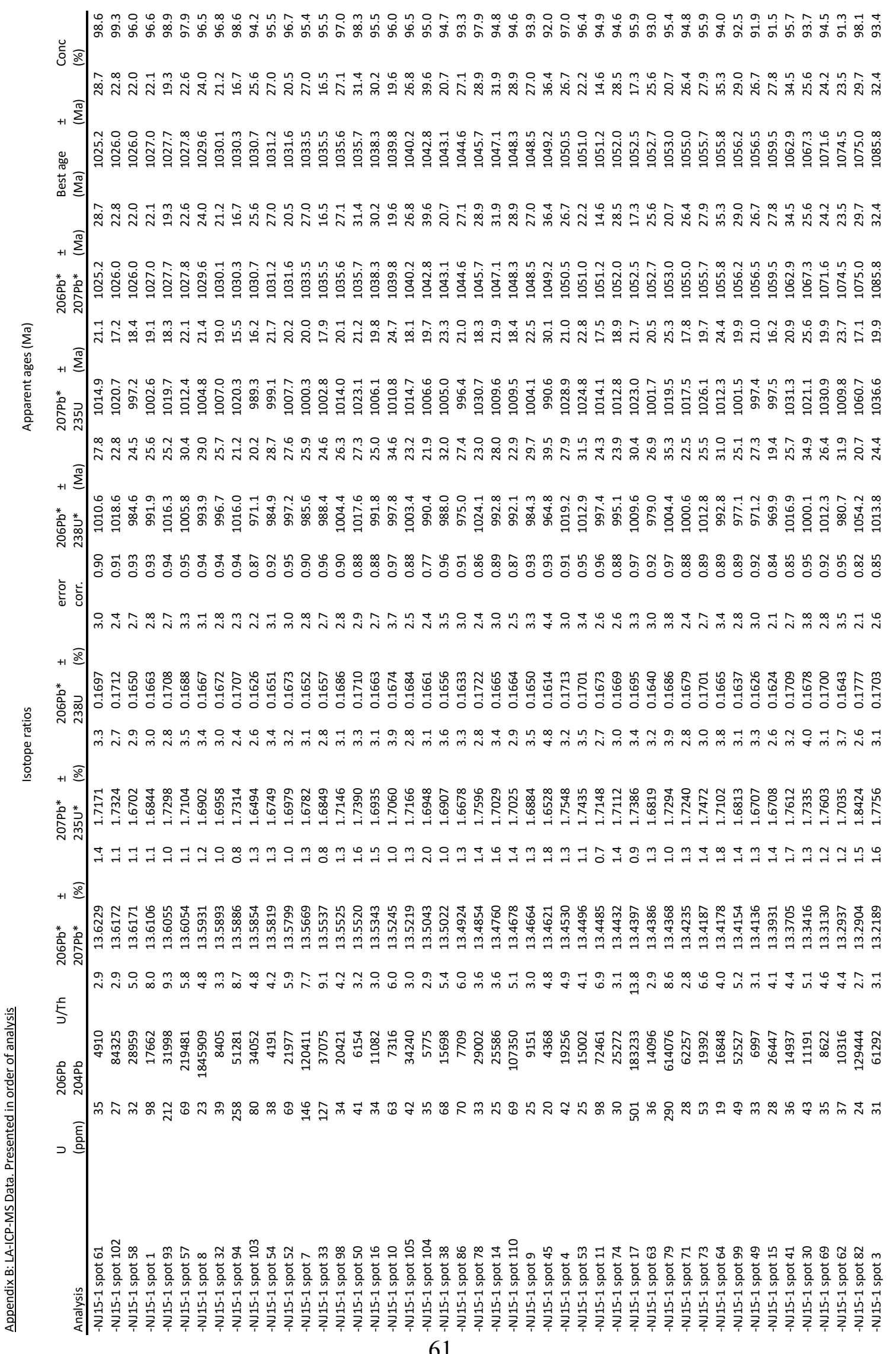




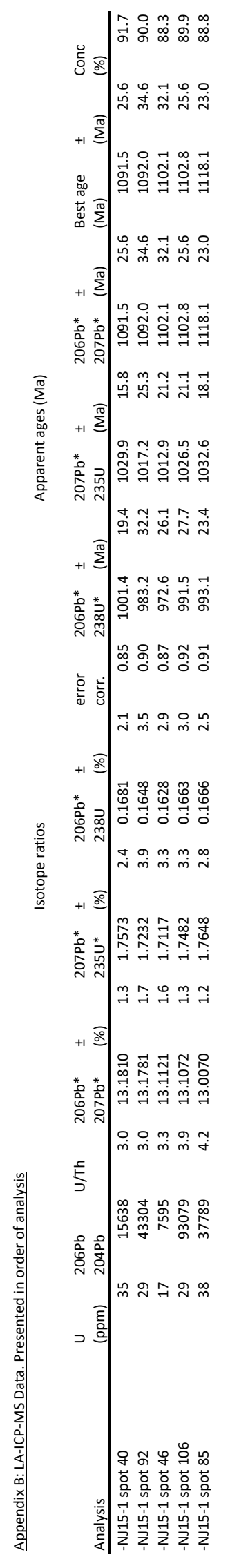




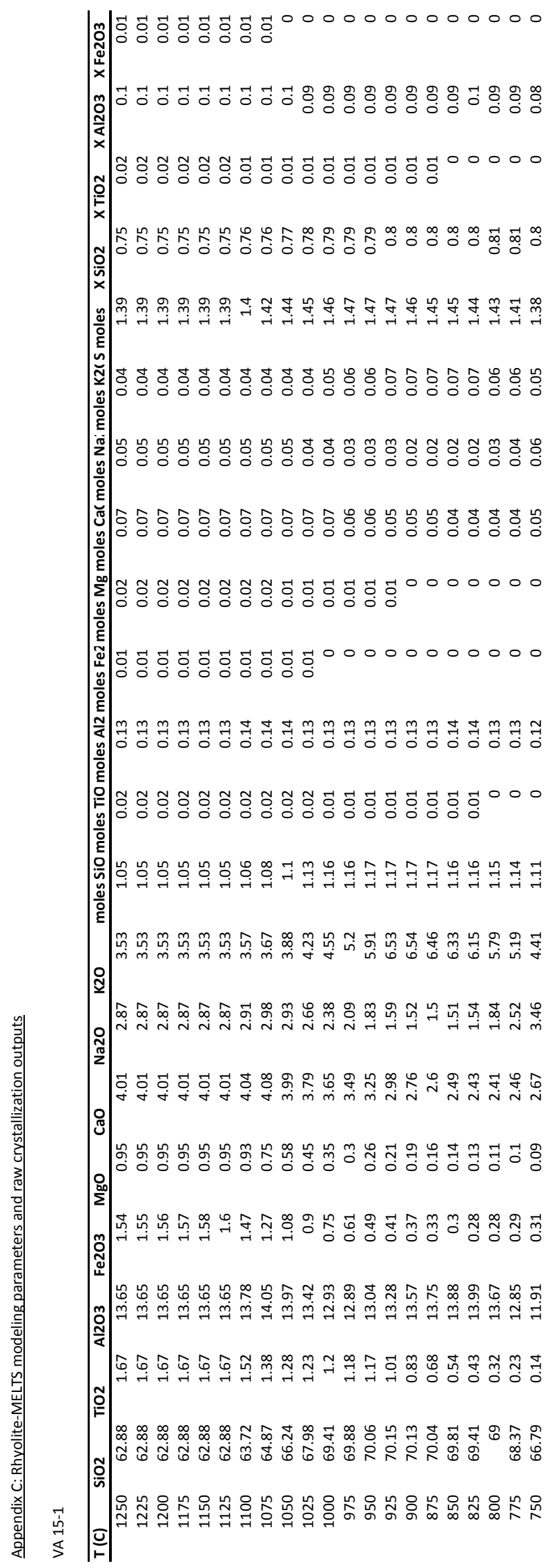

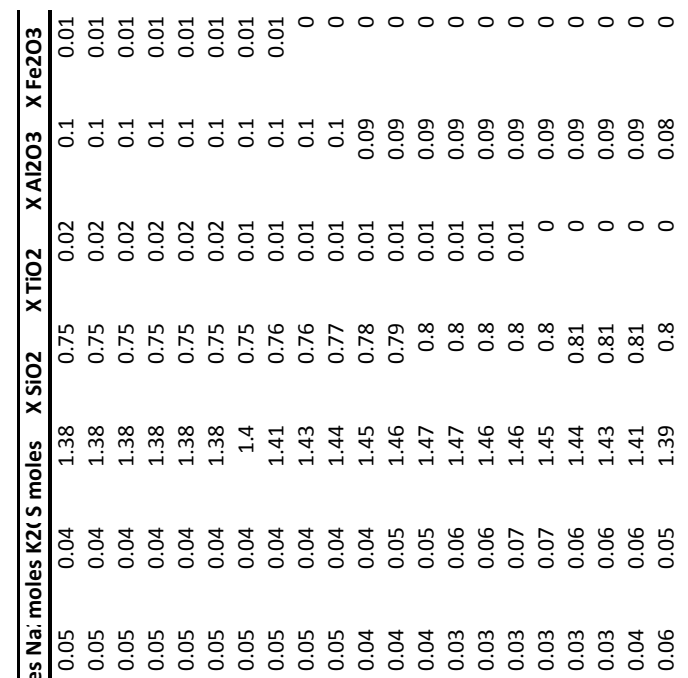

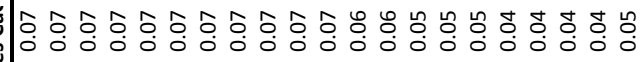

(1)

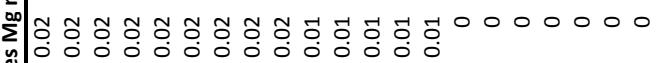

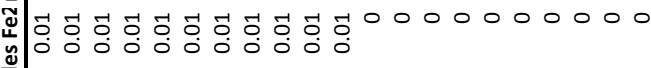

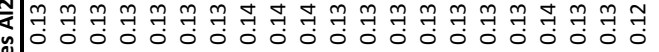

政

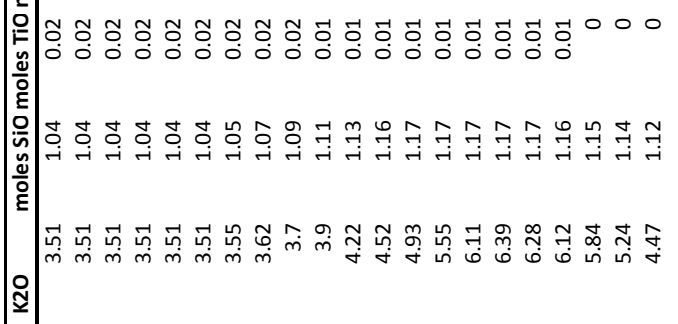

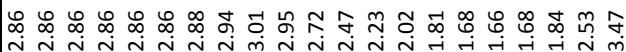

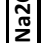

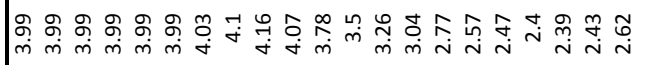
雨

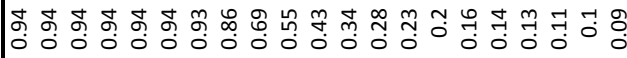
일

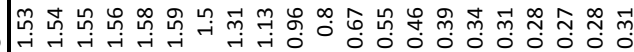

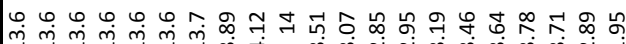
产

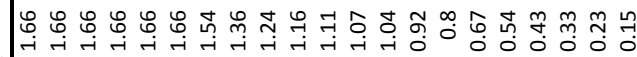
กั

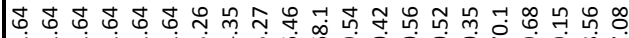
กิ نَ

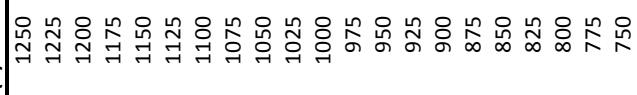




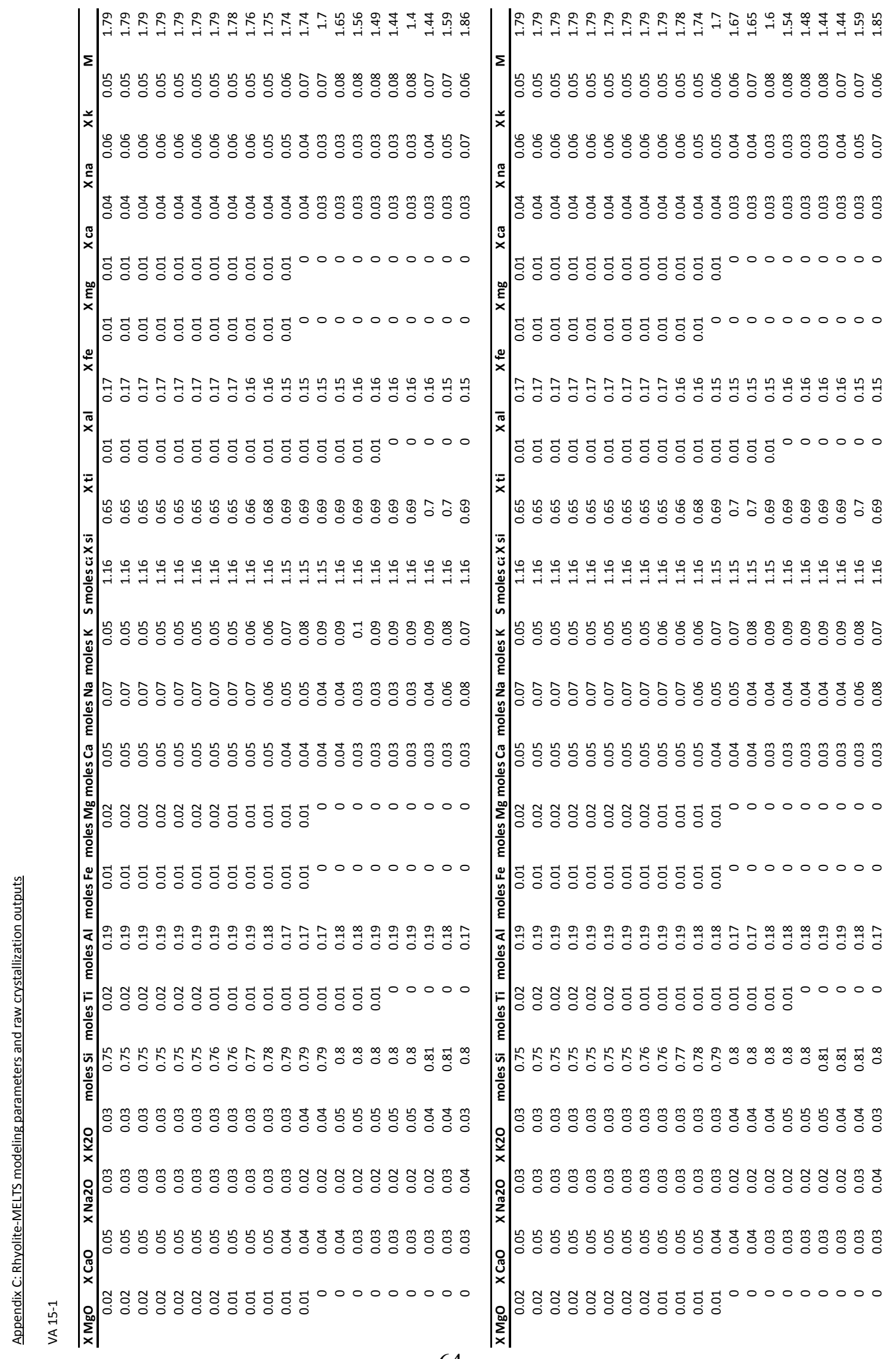




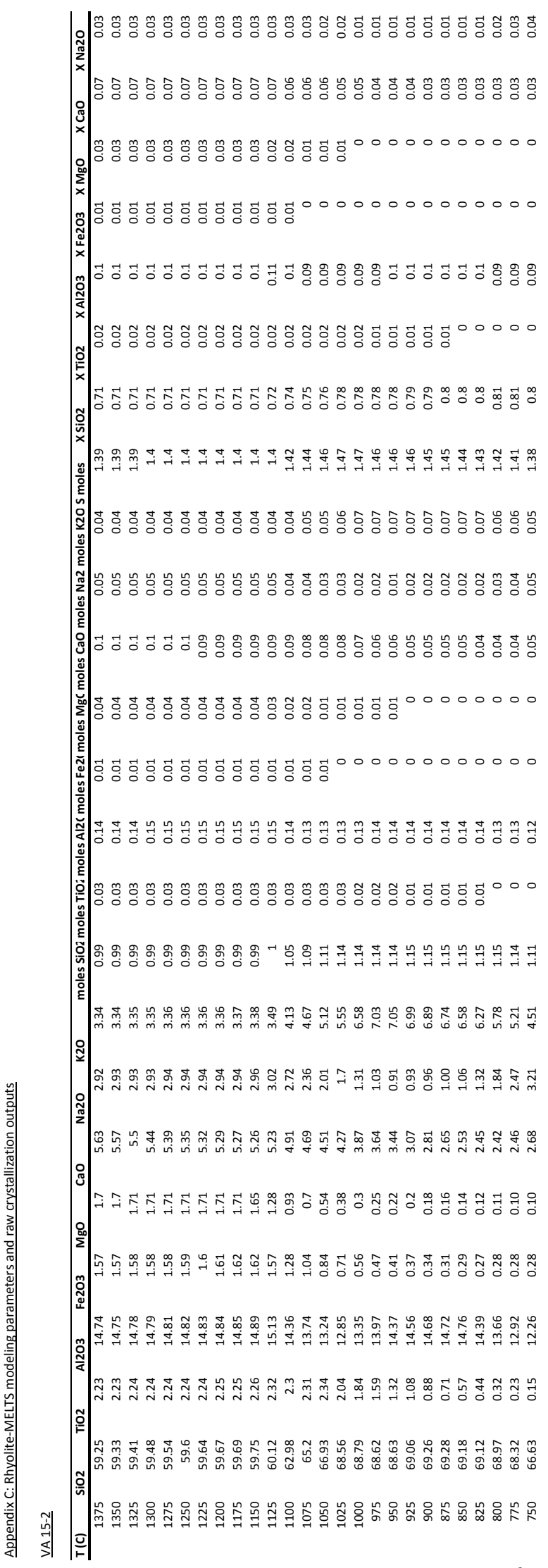

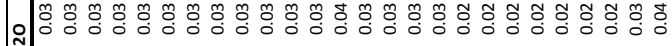
约 용

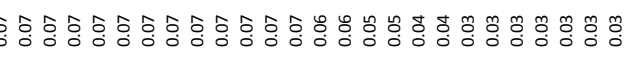

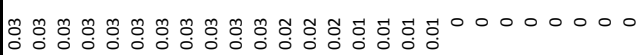

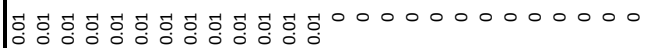

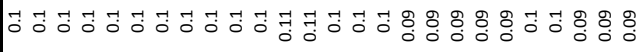

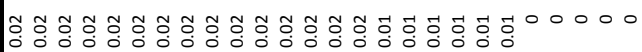

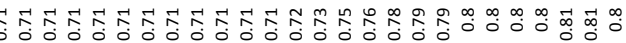

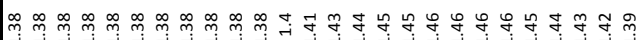

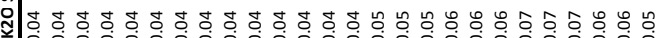
을

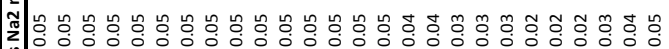

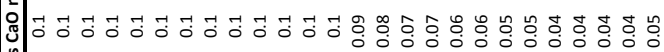
$\frac{\mathrm{or}}{\mathrm{0}}$

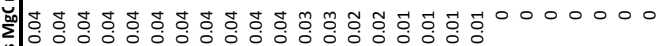
产

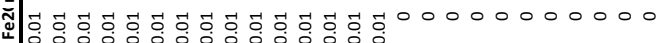
을

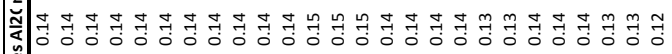

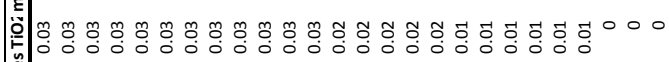
$\frac{2}{\circ}$

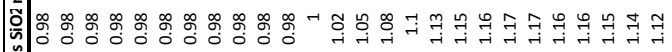
ㅎํำ

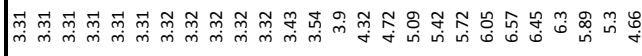
ชั

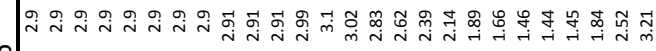
สำ

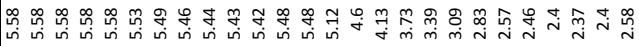
\%

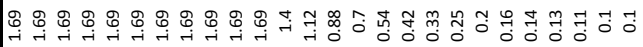
2.

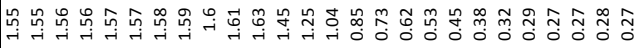
胥

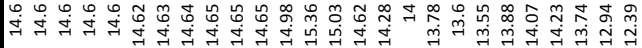
ชับ

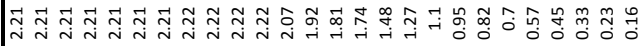
ธุก

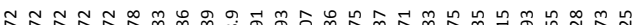

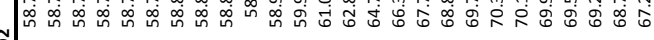

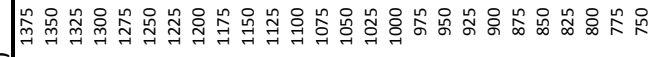
위 


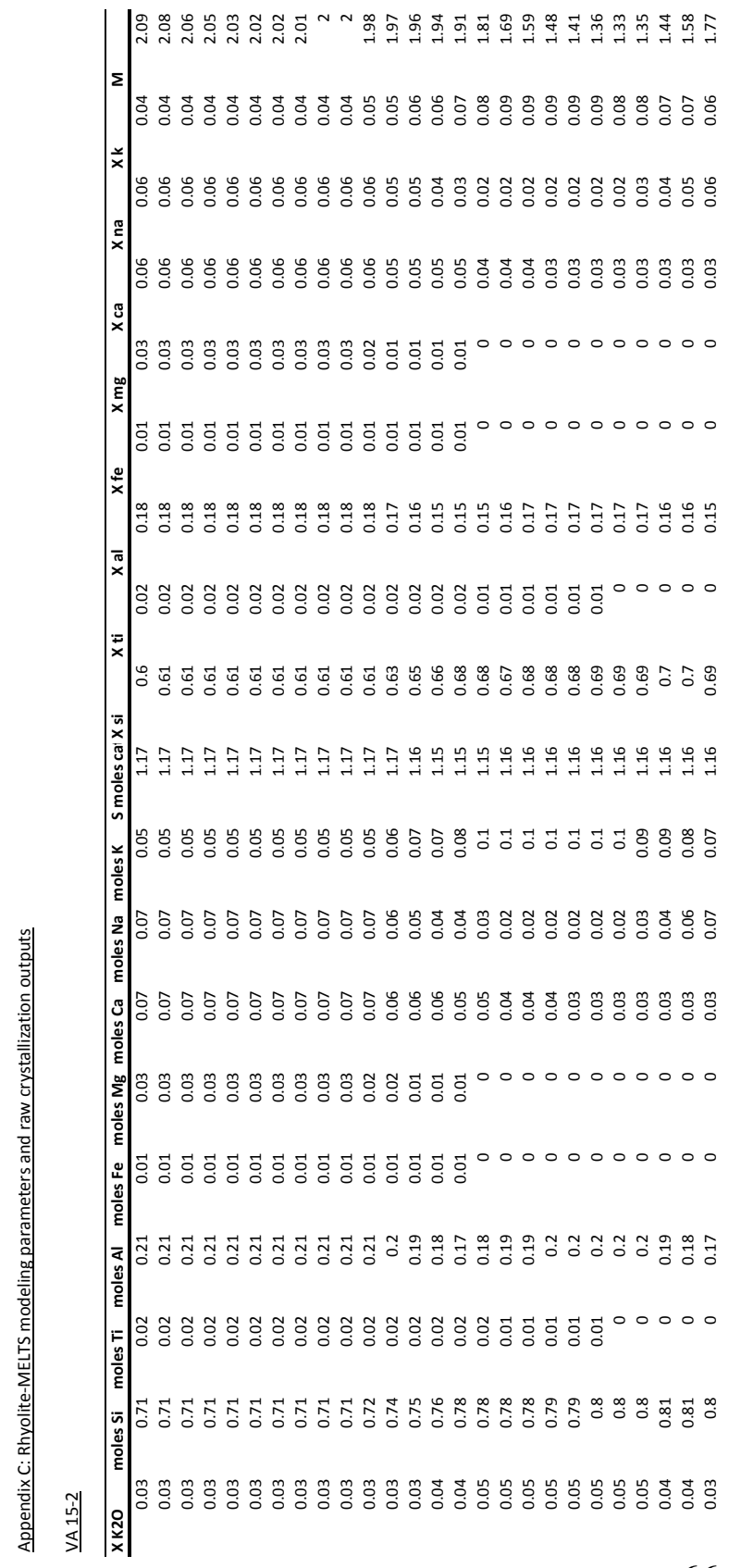

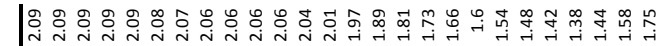
$\Sigma$

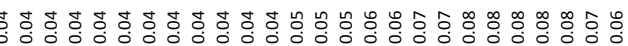
$\check{x}$

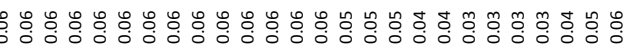
ฐ

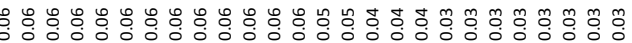

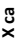

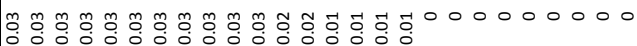
赵

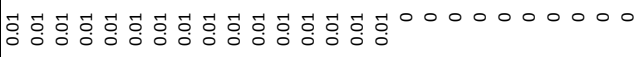

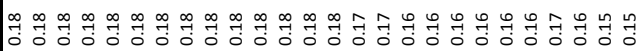
$\bar{x}$

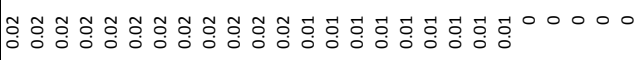

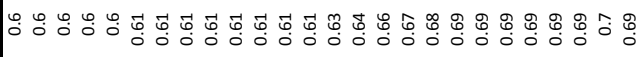

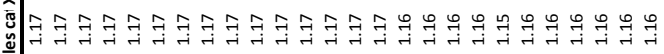

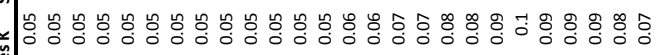

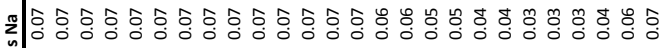

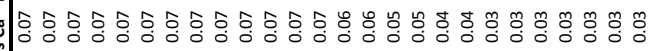

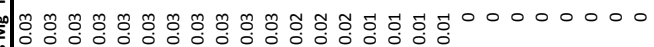
产

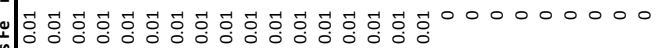
을

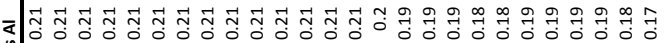
을

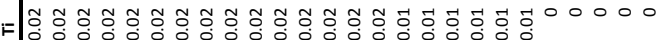
을

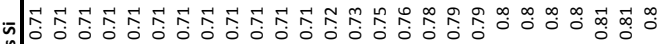
응

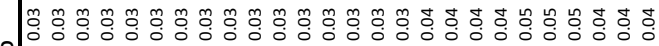




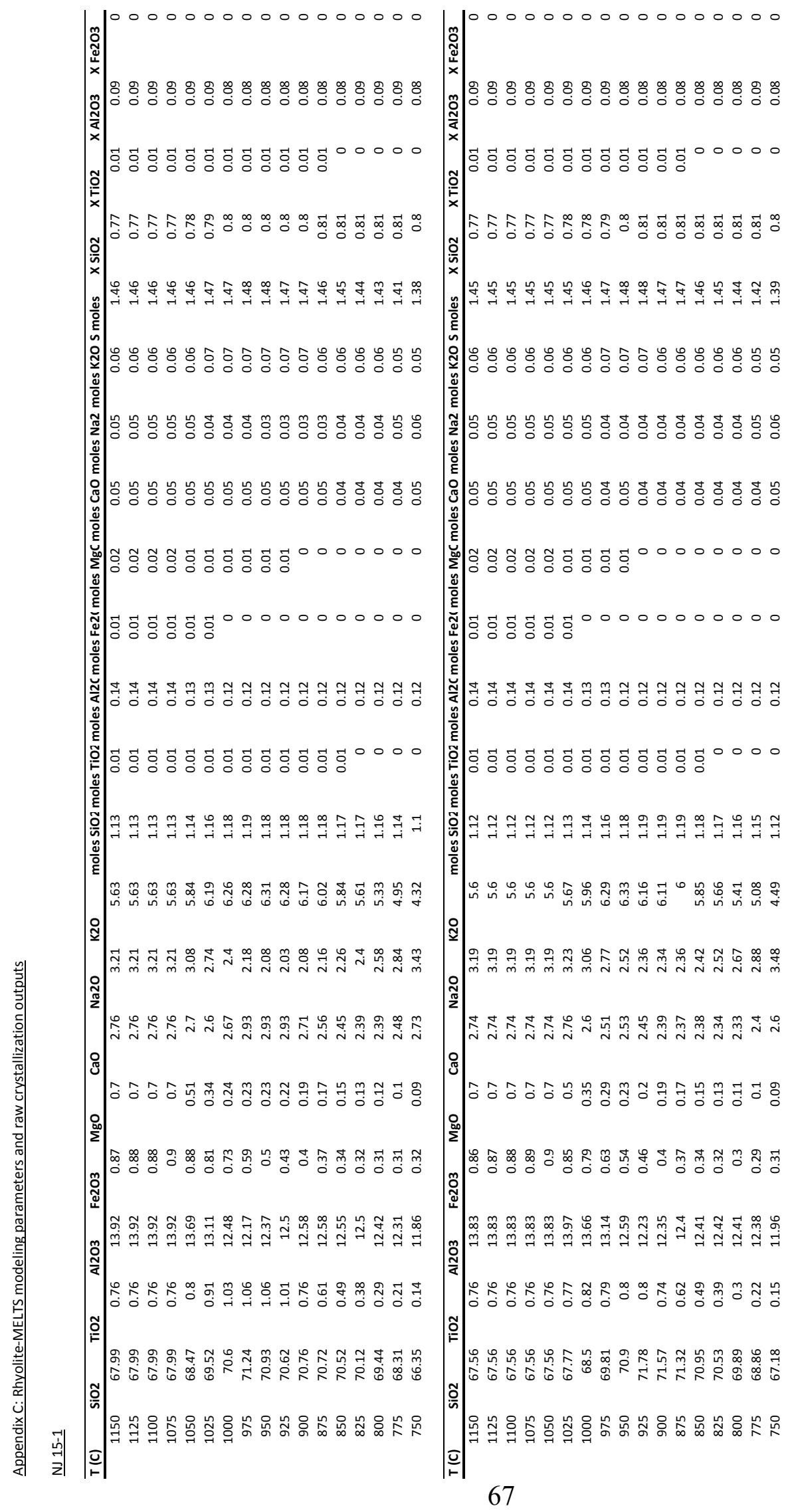




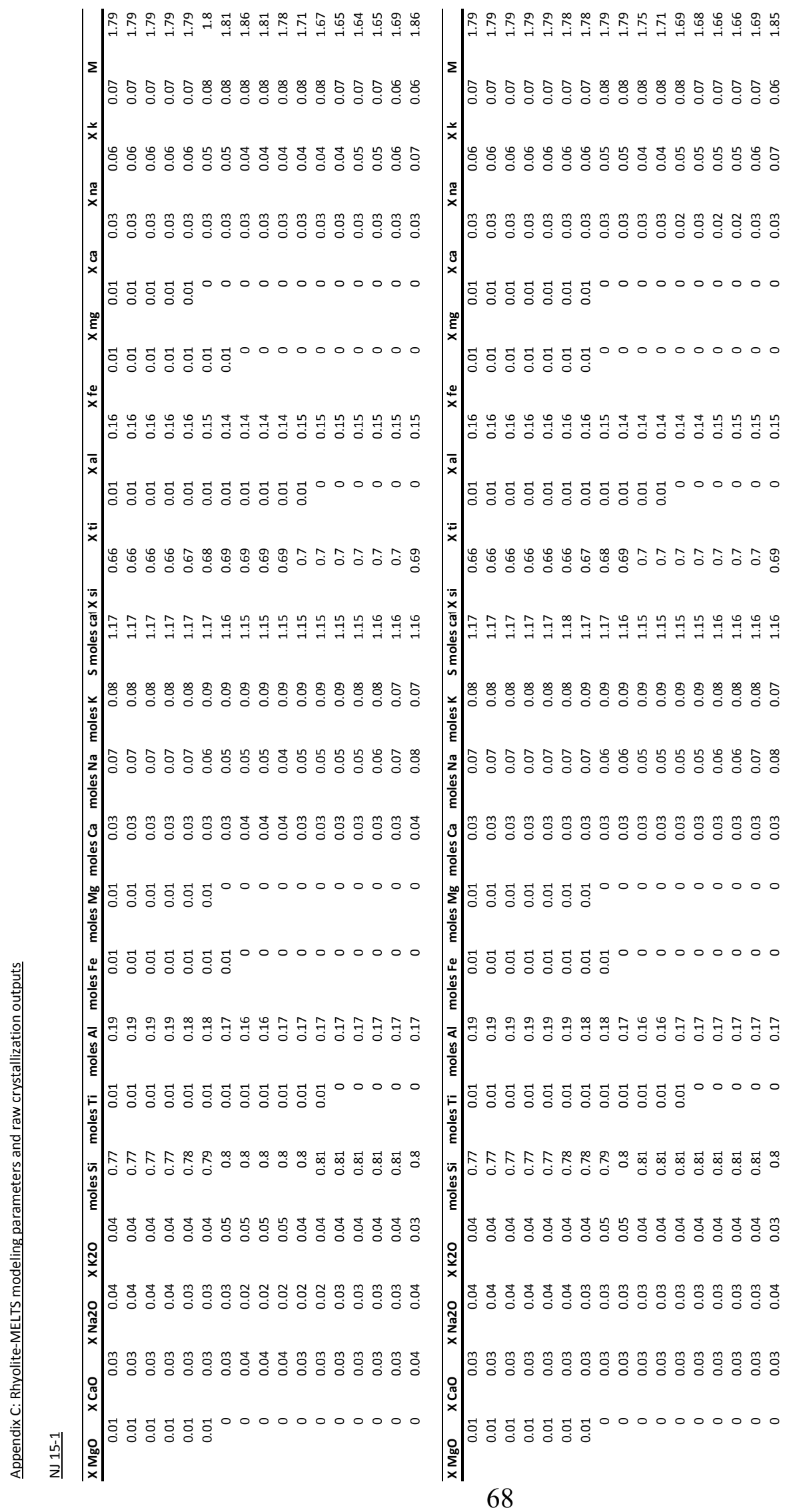




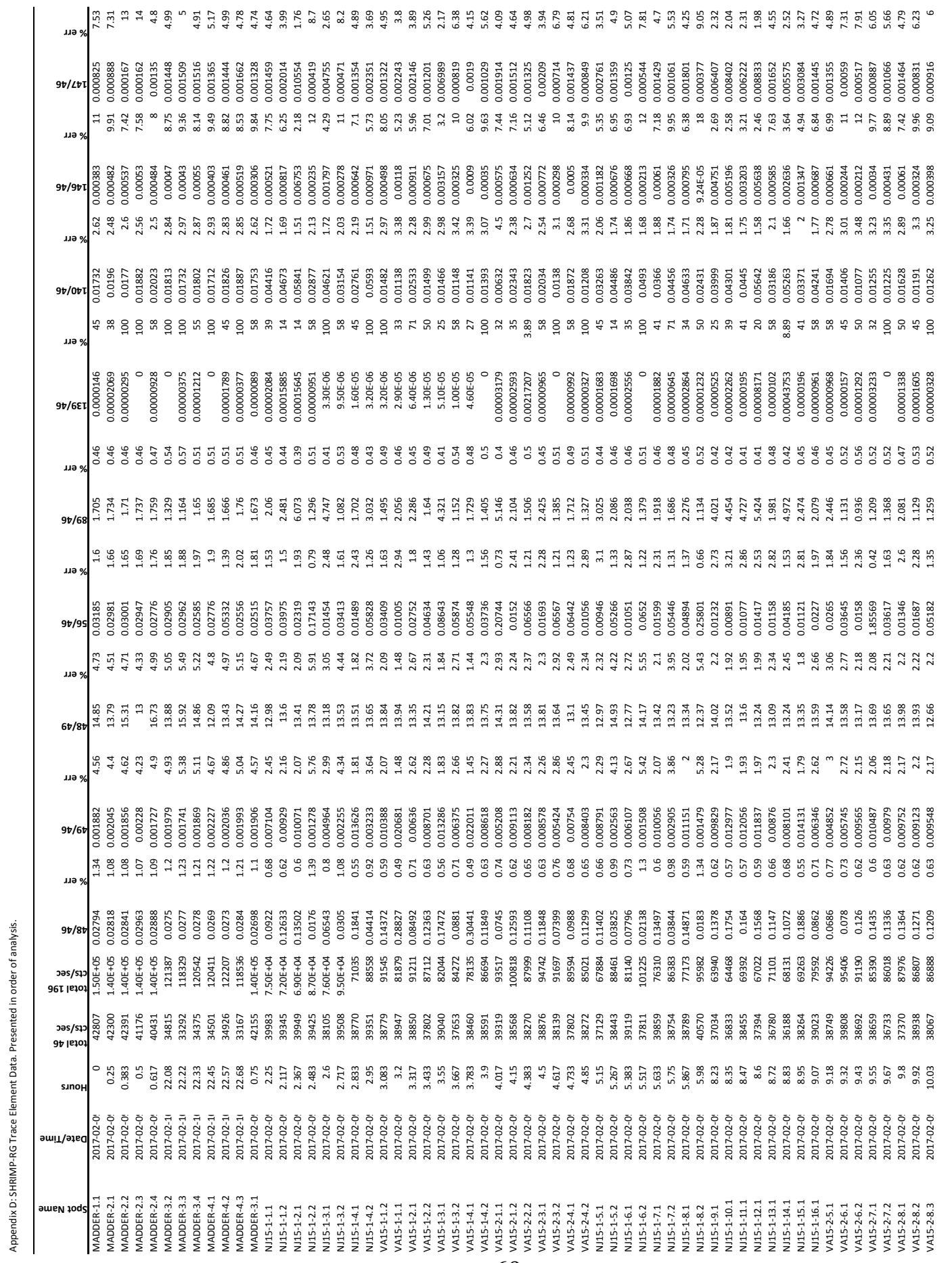




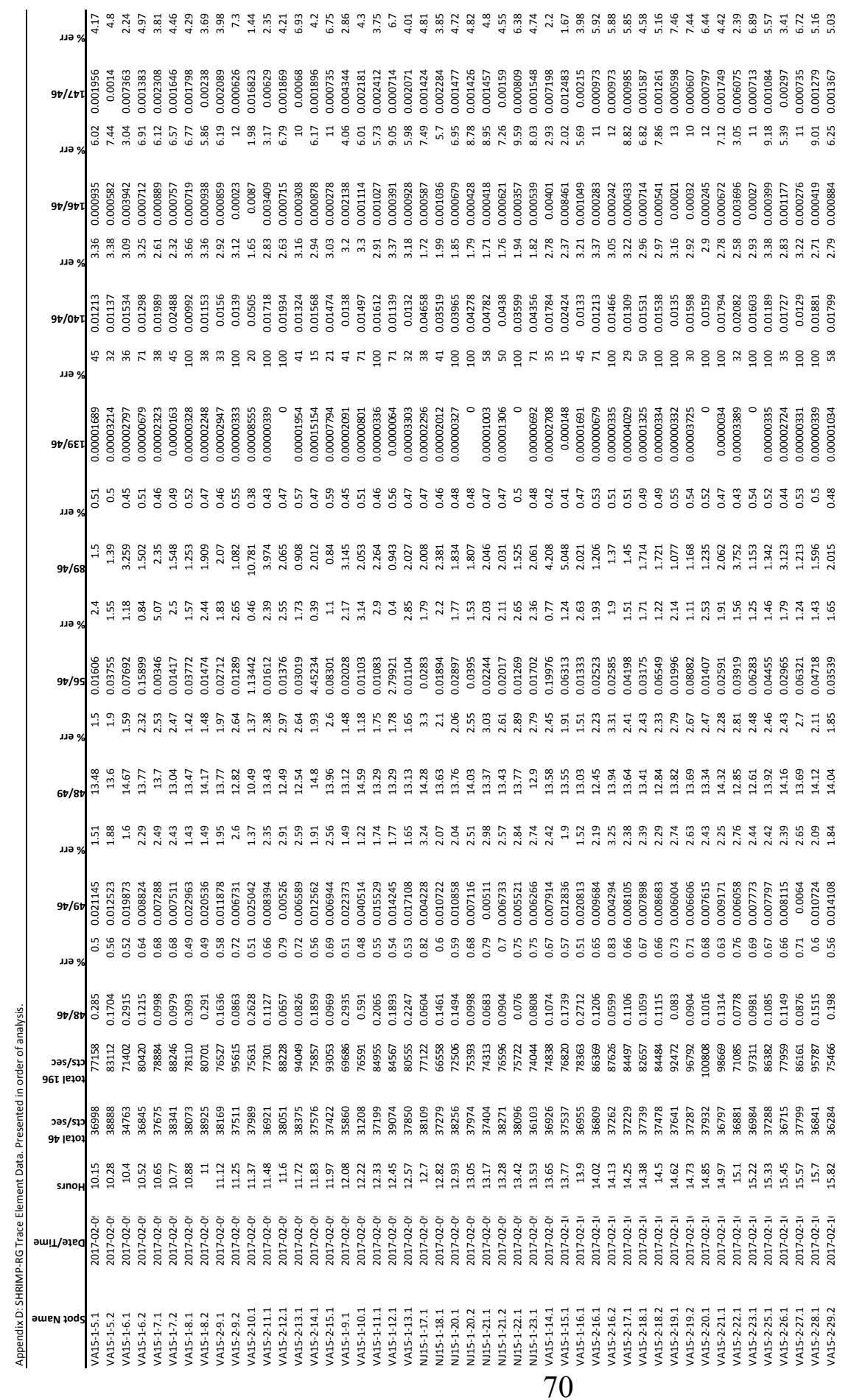




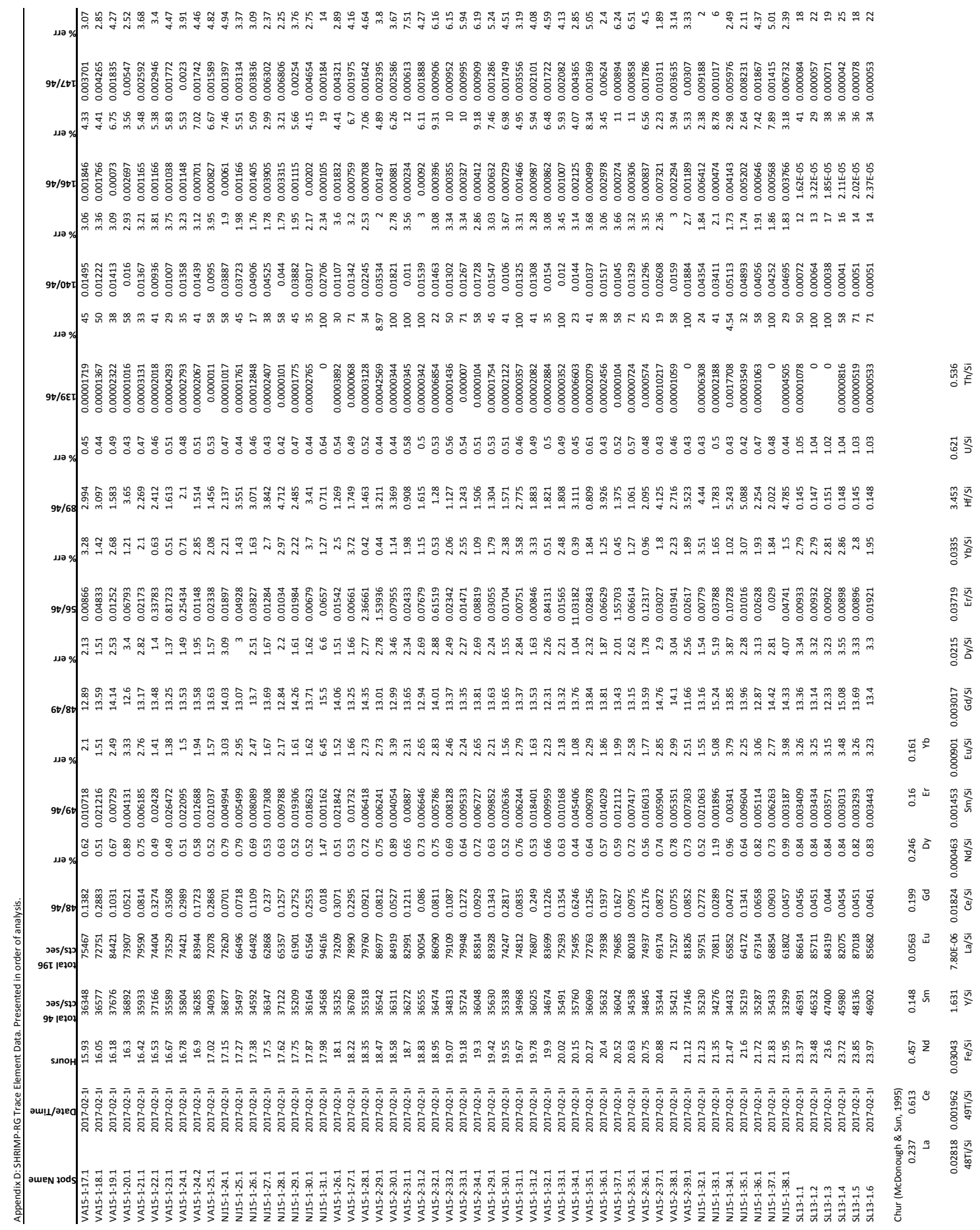




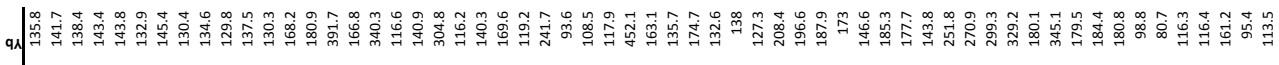

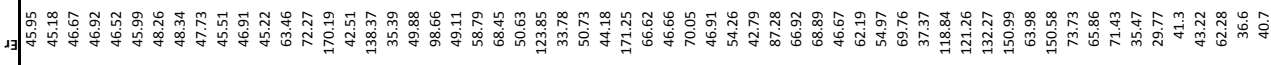

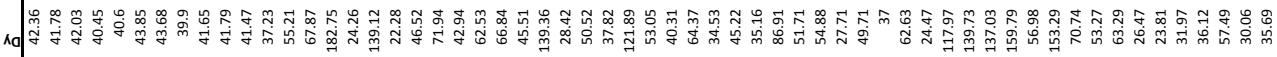

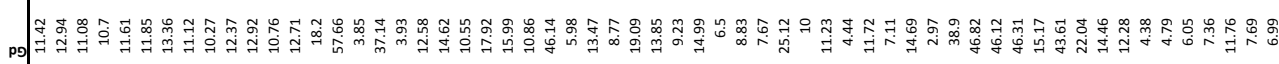

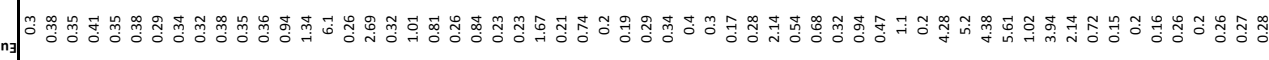

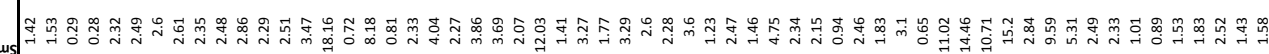

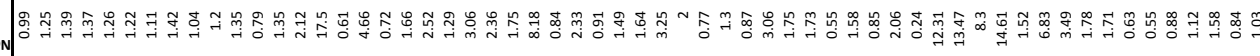

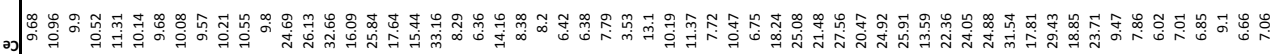

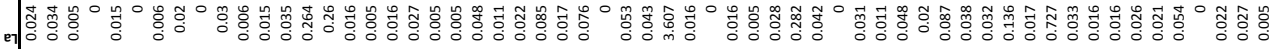

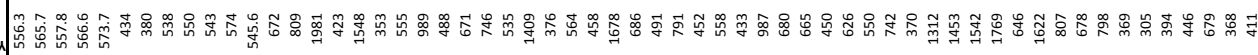

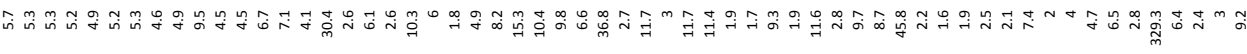

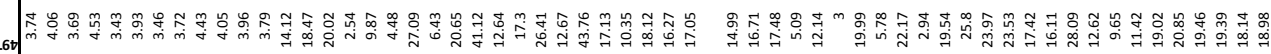

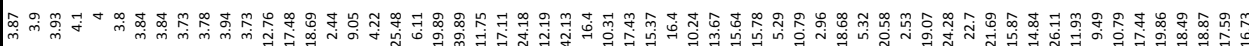

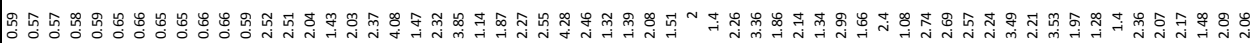

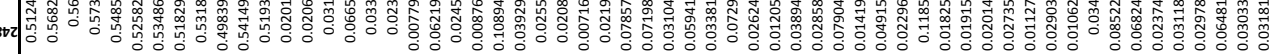

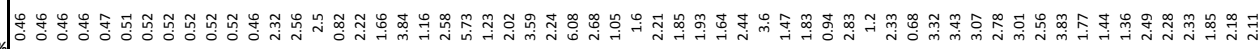
七/8r2

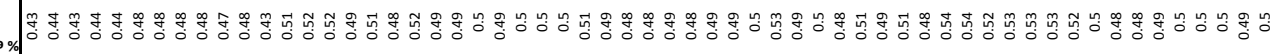

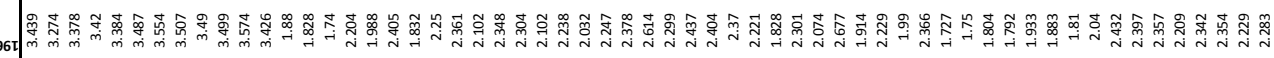

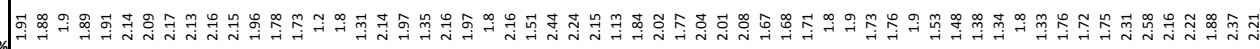

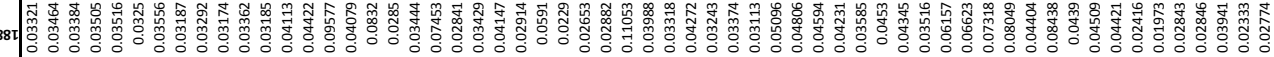

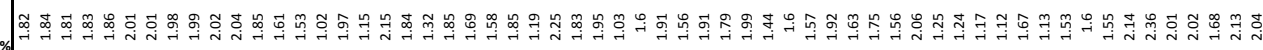

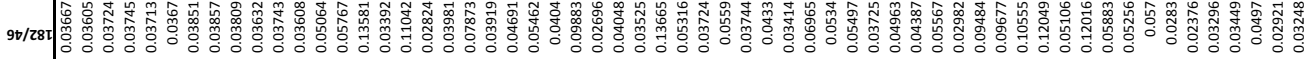

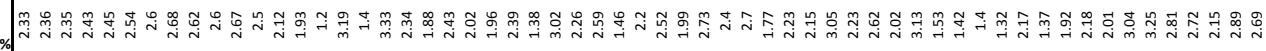

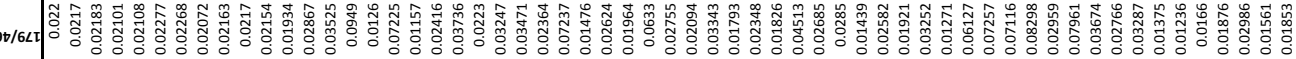

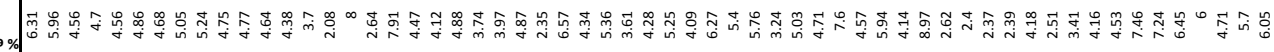
t/sst

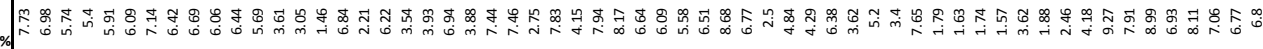




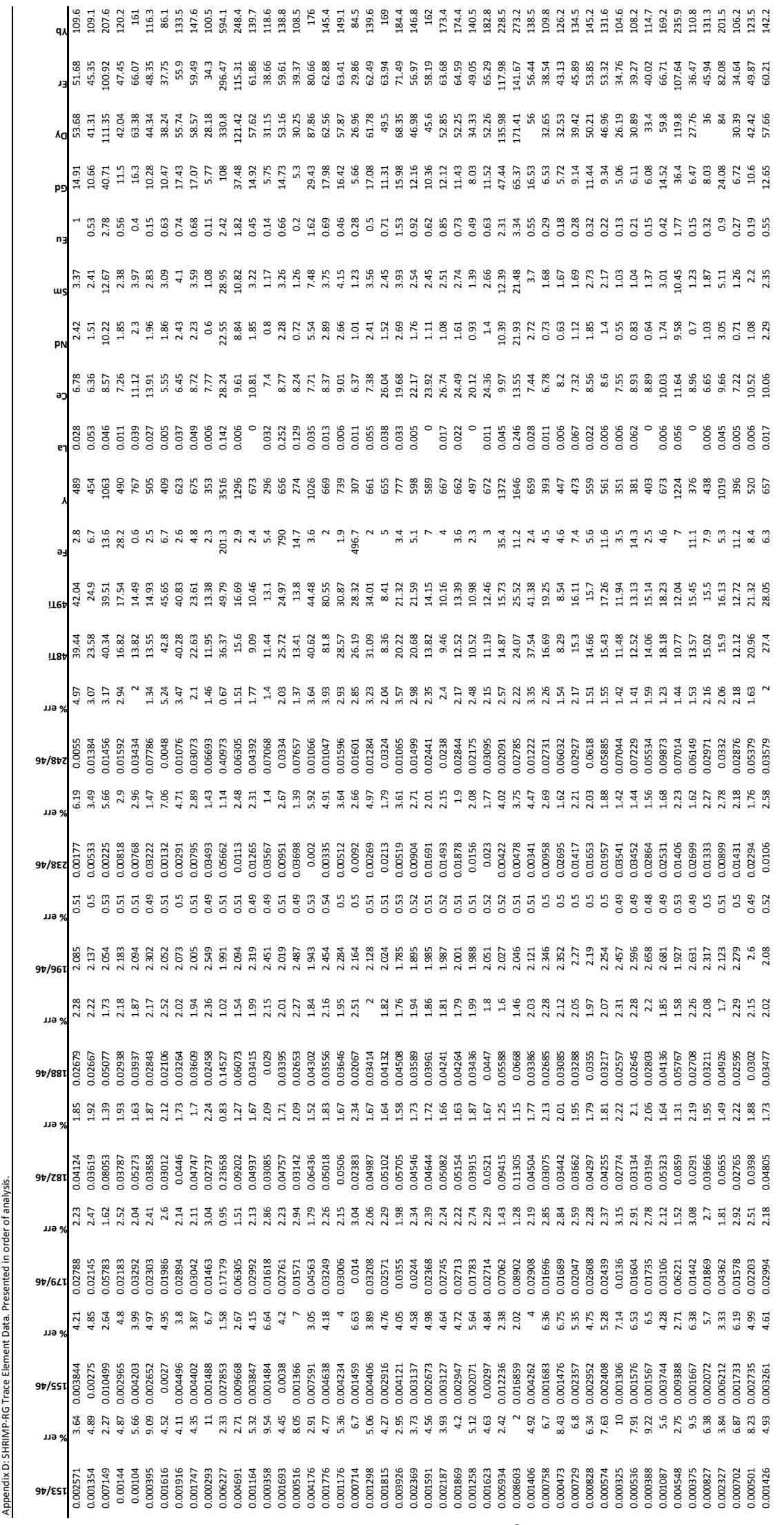




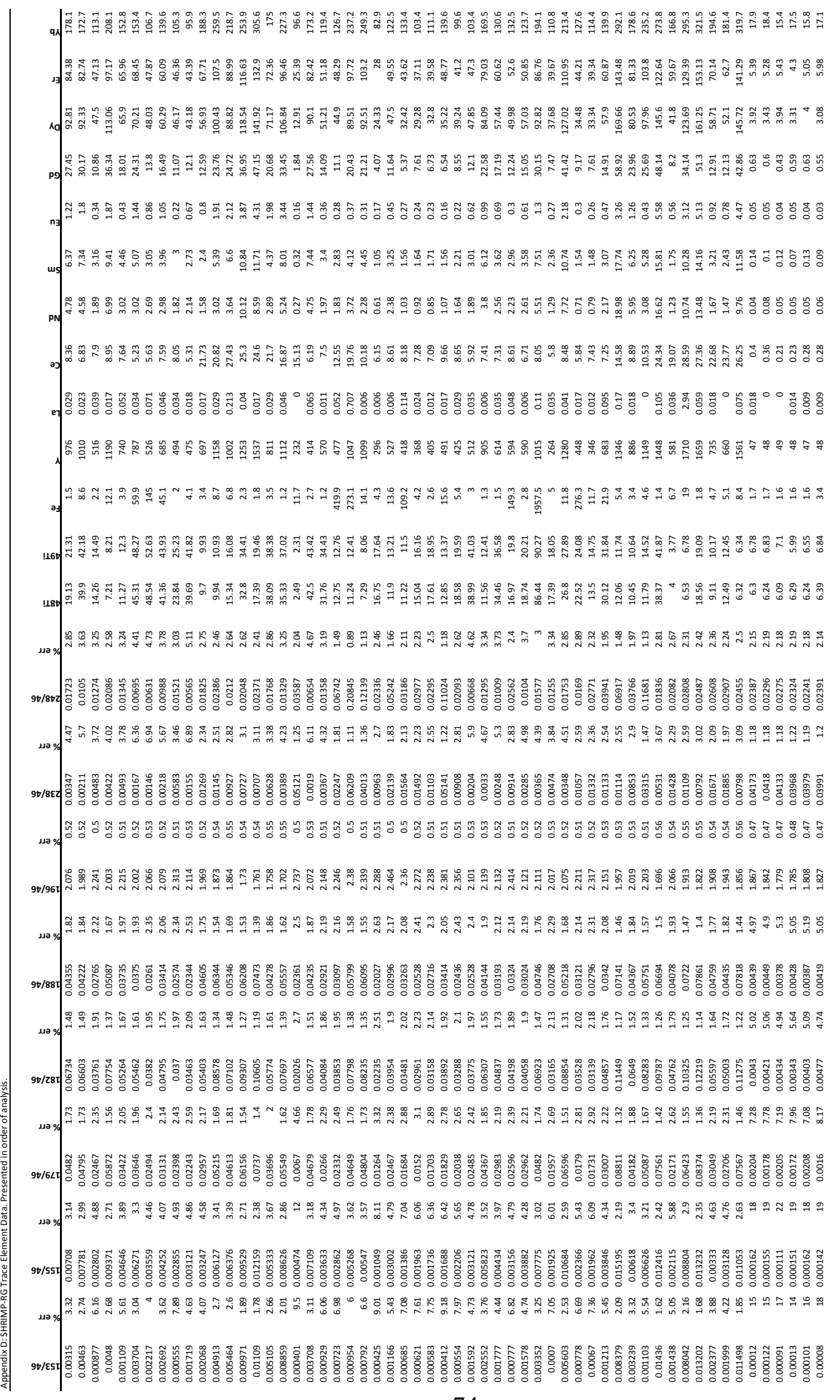




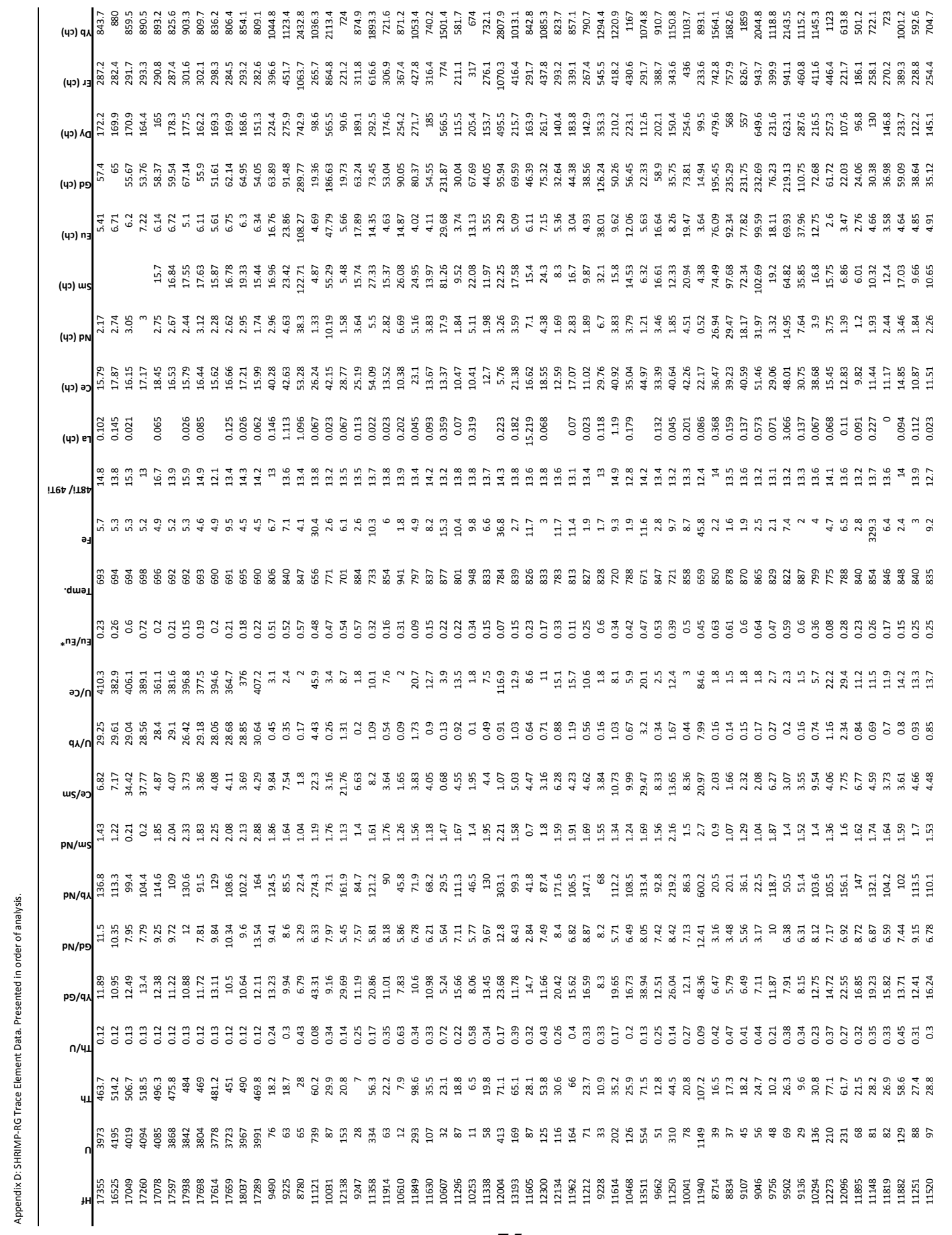




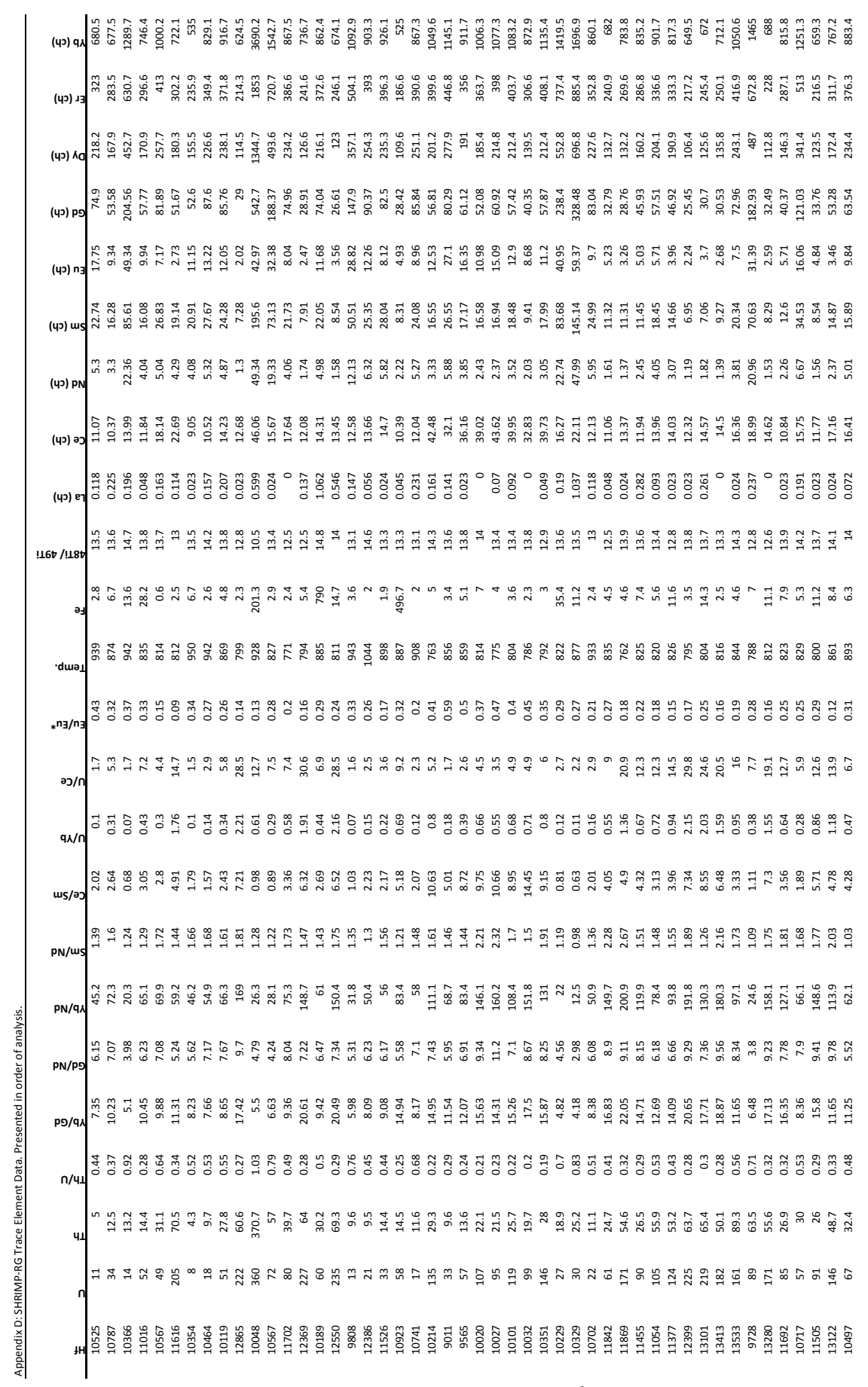




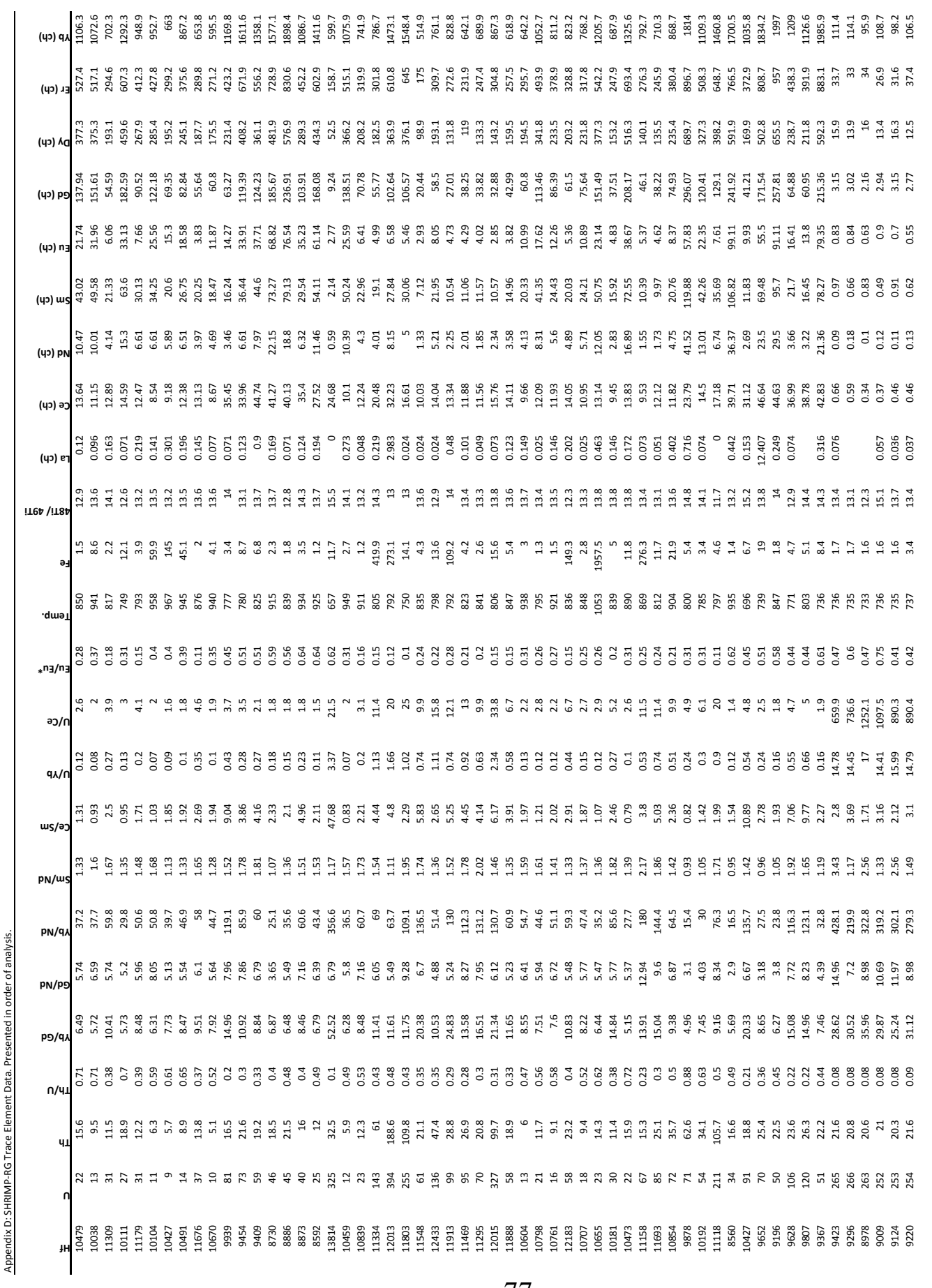




\section{REFERENCES}

Aleinikoff, J.N., Burton, W.C., Lyttle, P.T., Nelson, A.E., and Southworth, C.S., 2000, $\mathrm{U}-\mathrm{Pb}$ geochronology of zircon and monazite from Mesoproterozoic granitic gneisses of the northern Blue Ridge, Virginia and Maryland, USA: Precambrian Research, 99, no. 1, 113-146.

Aleinikoff, J.N., Horton, J.W., Jr., Drake, A.A., Jr, Wintsch, R.P., Fanning, C.M., and Yi, K., 2004, Deciphering multiple Mesoproterozoic and Paleozoic events recorded in zircon and titanite from the Baltimore Gneiss, Maryland; SEM imaging, SHRIMP U-Pb geochronology, and EMP analysis, in Tollo, R.P., Corriveau, L., McLelland, J., and Bartholomew, M. J., editors, Proterozoic tectonic evolution of the Grenville Orogen in North America: Geological Society of America Memoirs, v. 197, p. 411-434.

Annen, C., Blundy, J.D., and Sparks, R.S.J., 2006, The genesis of intermediate and silicic magmas in deep crustal hot zones: Journal of Petrology, v. 47, no. 3, p. 505-539.

Bartholomew, M.J., and Lewis, S.E., 1984, Evolution of Grenville massifs in the Blue Ridge geologic province, southern and central Appalachians, in Bartholomew, M.J., et al., eds., The Grenville event in the Appalachians and related topics: Geological Society of America Special Paper, v. 194, p. 229-254.

Beaumont, C., Jamieson, R., and Nguyen, M., 2010, Models of large, hot orogens containing a collage of reworked and accreted terranes: Canadian Journal of Earth Sciences, v. 47, p. 485-515.

Bonin, B., 2007, A-type granites and related rocks: Evolution of a concept, problems and prospects: Lithos, v. 97, p. 1-29.

Brown, M., and Raith, M., 1996, First evidence of ultrahigh-temperature decompression from the granulite province of southern India: Journal of the Geological Society, London, v. 153, p. 819-822.

Burton, W.C., and Southworth, S., 2010, A model for Iapetan rifting of Laurentia based on Neoproterozoic dikes and related rocks: Geological Society of America Memoirs, v. 206, p. 1-22.

Corfu F., Hanchar J.M., Hoskin P.W.O. and Kinny P, 2003, Atlas of zircon textures. In: Zircon (edited by J.M. Hanchar and P.W.O Hoskin), Reviews in Mineralogy and Geochemistry, Mineralogical Society of America: v. 53, p. 468-500.

Drake, A.A., Jr., Aleinikoff, J.N., and Volkert, R.A., 1991, The Mount Eve Granite (Middle Proterozoic) of northern New Jersey and southeastern New York, in Drake, A.A., Jr., ed., Contributions to New Jersey geology: Reston, Virginia, U.S. Geological Survey Bulletin, v. 1952, p. C1-C10. 
Ferry, J.M., and Watson, E.B., 2007, New thermodynamic models and revised calibrations for the Ti-in-zircon and Zr-in-rutile thermometers: Contributions to Mineralogy and Petrology, v. 154, p. 429-437.

Fu, B., Page, F.Z., Cavosie, A.J., Fournelle, J., Kita, N.K., Lackey, J.S., Wilde, S.A., and Valley, J.W., 2008, Ti-in-zircon thermometry: applications and limitations: Contributions to Mineralogy and Petrology, v. 156, p. 197-215.

Gehrels, G.E., Valencia, V. a., and Ruiz, J., 2008, Enhanced precision, accuracy, efficiency, and spatial resolution of $\mathrm{U}-\mathrm{Pb}$ ages by laser ablation-multicollectorinductively coupled plasma-mass spectrometry: Geochemistry, Geophysics, Geosystems, v. 9, no. 1, p. n/a-n/a

Ghiorso, M., Sack, R., 1995, Chemical mass transfer in magmatic processes. IV. A revised and internally consistent thermodynamic model for the interpolation and extrapolation of liquid-solid equilibria in magmatic systems at elevated temperatures and pressures: Contributions to Mineralogy and Petrology, v. 119, p. 197-212.

Ghiorso, M.S., and Gualda, G.A.R., 2013, A method for estimating the activity of titania in magmatic liquids from the compositions of coexisting rhombohedral and cubic iron-titanium oxides: Contributions to Mineralogy and Petrology, v. 165, p. 7381.

Gorring, M.L., Estelle, T.C., and Volkert, R.A., 2004, Geochemistry of the Late Mesoproterozoic Mount Eve granite suite: Implications for Late to post-Ottawan tectonics in the New Jersey-Hudson Highlands: Geological Society of America Memoirs, v. 197, p. 505-523.

Gualda, G.A.R., Ghiorso, M.S., Lemons, R.V., and Carley, T.L., 2012, Rhyolite-MELTS: A modified calibration of MELTS optimized for silica-rich, fluid bearing magmatic systems: Journal of Petrology, v. 53, p. 875- 890.

Hanchar, J.M., and Miller, C.F., 1993, Zircon zonation patterns as revealed by cathodoluminescence and backscattered electron images: Implications for interpretation of complex crustal histories: Chemical Geology, v. 110, p. 1-13.

Harrison, T.M., Watson, E.B., and Aikman, A.B., 2007, Temperature spectra of zircon crystallization in plutonic rocks: Geology, v. 35, p. 635-638.

Hiess, J., Nutman, A.P., Bennett, V.C., and Holden, P., 2008, Ti-in-zircon thermometry applied to contrasting Archean metamorphic and igneous systems: Chemical Geology, v. 247, p. 323-338. 
Hoskin, P.W.O., and Schaltegger, Urs., 2003, The composition of zircon and igneous and metamorphic petrogenesis: Reviews in Mineralogy and Geochemistry, v. 53, p. 27-62.

Hughes, S.S., Lewis, S.E., Bartholomew, M.J., Sinha, A.K., Hudson, T.A., and Herz, T., 1997, Chemical diversity and origin of the Precambrian charnockitic rocks of the central Pedlar massif, Grenvillian Blue Ridge Terrane, Virginia: Precambrian Research, v. 84, p. 37-62.

Hughes, S.S., Lewis, S.E., Bartholomew, M.J., Sinha, A.K., and Herz, N., 2004, Geology and geochemistry of granitic and charnockitic rocks in the central Lovington massif of the Grenvillian Blue Ridge terrane: Geological Society of America Memoirs, v. 197, p. 549-569.

Kelsey, D.E., and Hand, M., 2014, On ultrahigh temperature crustal metamorphism: Phase equilibria, trace element thermometry, bulk composition, heat sources, timescales and tectonic settings: Geoscience Frontiers, v. 6, p. 311-356.

Ludwig, K.R., 2012, Isoplot v3.75: a user’s manual: Berkeley Geochronology Center Special Publication No. 5, 75 p.

Ludwig, K.R., 2009, SQUID 2: a user’s manual: Berkeley Geochronology Center Special Publication No. 2, 100 p.

McDonough, W.F., and Sun, S.S., 1995, The composition of the Earth: Chemical Geology, v. 120, no. 3, p. 223-253.

McLelland, J., Daly, J.S. and McLelland, J.M., 1996, The Grenville orogenic cycle (ca. 1350-1000 Ma): an Adirondack perspective, Tectonophysics, v. 265, no.1, p.1-28.

Miller, C.F., McDowell, S.M., and Mapes, R.W., 2003, Hot and cold granites? Implications of zircon saturation temperatures and preservation of inheritance: Geology, v. 31, p. 529-532.

Moecher, D.P., McDowell, S.M., Samson, S.D., and Miller, C.F., 2014, Ti-in-zircon thermometry and crystallization modeling support "hot" Grenville granite hypothesis: Geology, v. 42, p. 267-270.

Moecher, D.P., and Samson, S.D., 2006, Differential zircon fertility of source terranes and natural bias in the detrital zircon record: Implications for sedimentary provenance analysis: Earth and Planetary Science Letters, v. 247, p. 252-266. 
Paces, J.B. and Miller, J.D., 1993, Precise U-Pb ages of Duluth complex and related mafic intrusions, northeastern Minnesota: Geochronological insights to physical, petrogenetic, paleomagnetic, and tectonomagmatic processes associated with the 1.1 Ga midcontinent rift system: Journal of Geophysical Research: Solid Earth, v. 98, no. B8, p.13997-14013.

Padilla, A.J., Miller, C.F., Carley, T.L., Economos, R.C., Schmitt, A.K., Coble, M.A., Wooden, J.L., Fisher, C.M., Vervoort, J.D., and Hanchar, J.M., 2016, Elucidating the magmatic history of the Austurhorn silicic intrusive complex (southeast Iceland) using zircon elemental and isotopic geochemistry and geochronology: Contributions to Mineralogy and Petrology, v. 171, p. 1-21.

Pamucku, A.S., Carley, T.L., Gualda, G.A.R., Miller, C.F. and Ferguson, C.A., 2013, The evolution of the Peach Spring Giant Magma Body: Evidence from accessory mineral textures and compositions, bulk pumice and glass geochemistry, and rhyolite-MELTS modeling: Journal of Petrology, v. 54, p. 1109-1148.

Rankin, D.W., 1975, The continental margin of eastern North America in the southern Appalachians: The opening and closing of the Proto-Atlantic ocean: American Journal of Science, v. 279A, p. 298-336.

Rankin, D.W., Drake Jr., A.A., Glover III, L., Goldsmith, R., Hall, L.M., Murray, D.P., Ratcliffe, N.M., Read, J.F., Secor Jr., D.T., and Stanley, R.S., 1989, Pre-orogenic terranes. In: Hatcher Jr., R.D., Thomas, W.A., Viele, G.W. (Eds.), The Appalachian-Ouachita orogen in the United States: Boulder, Colorado. Geological Society of America, The Geology of North America, v. F-2, p. 7-100.

Rino, S., Yon, Y., Sato, W., Maruyama, S., Santosh, M., and Zhao, D., 2008, The Grenvillian and Pan African orogens: World's largest orogenies through geologic time, and their implications on the origin of superplumes: Gondwana Research, v. 14, p. 51-72.

Rivers, T., 2008, Assembly and preservation of lower, mid, and upper orogenic crust in the Grenville Province-Implications for the evolution of large hot long-duration orogens: Precambrian Research, v. 167, p. 237-259.

Rivers, T., 1997, Lithotectonic elements of the Grenville province: Precambrian Res. 86, $117-154$.

Rivers, T., 2009, The Grenville Province as a large hot long-duration collisional orogen: Insights from the spatial and temporal of its orogenic fronts, in Murphy, J.B., et al., eds., Ancient orogens and modern analogues: Geological Society of London Special Publication, v. 327, p. 405-444. 
Schmitt, A.K, Grove, M., Harrison, T.M., Lovera, O., Hulen, J., and Walters, M., 2003, The Geysers - Cobb Mountain Magma System, California (Part 1): U-Pb zircon ages of volcanic rocks, conditions of zircon crystallization and magma residence times: Geochimica et Cosmochimica Acta, v. 67, p. 3423-3442.

Schmitz, M.D., Bowring, S.A., and Ireland, T.R., 2002, Evaluation of Duluth Complex anorthositic series (AS3) zircon as a U-Pb geochronological standard: New highprecision isotope dilution thermal ionization mass spectrometry results: Geochimica et Cosmochimica Acta, v. 67, no. 19, p. 3665-3672.

Siebel, W., Shang, C.K., Thern, E., Danisik, M., and Rohrmuller, J., 2012, Zircon response to high-grade metamorphism as revealed by U-Pb and cathodoluminescence studies: International Journal of Earth Science, v.101, p. 2105-2123.

Smithies, R.H., Howard, H.M., Evins, P.M., Kirkland, C.L., Kelsey, D.E., Hand, M., Wingate M.T.D., Collins, A.S., and Belousova, E., 2011, High-temperature granite magmatism, crust-mantle interaction and the Mesoproterozoic intracontinental evolution of the Musgrave Province, Central Australia: Journal of Petrology, v. 52, no. 5, p. 931-958.

Southworth, S., Aleinikoff, J.N., Tollo, R.P., Bailey, C.M., Burton, W.C., Hackley, P.C., and Fanning, C.M., 2010, Mesoproterozoic magmatism and deformation in the northern Blue Ridge, Virginia and Maryland: Application of SHRIMP U-Pb geochronology and integrated field studies in the definition of Grenville tectonic history. Geological Society of America Memoirs, v. 206, p. 859-896.

Tollo, R.P., Bailey, C., Borduas, E., and Aleinikoff, J., 2004a, Mesoproterozoic geology of the Blue Ridge province in north-central Virginia: Petrologic and structural perspectives on Grenvillian orogenesis and Paleozoic tectonic processes: Geology of the National Capital Region - Field Trip Guidebook. USGS Circular 1264, 1775.

Tollo, R.P., Aleinikoff, J. N., Wooden, J. L., Mazdab, F. K., Southworth, S., and Fanning, C. M., 2010, Thermomagmatic evolution of Mesoproterozoic crust in the Blue Ridge of SW Virginia and NW North Carolina: Evidence from U-Pb geochronology and zircon geothermometry: Geological Society of America Memoirs, v. 206, p. 859-896.

Tollo, R.P., Aleinikoff, J., Borduas, E., and Hackley, P., 2004b, Petrologic and geochronologic evolution of the Grenville orogeny, northern Blue Ridge province, Virginia: Geological Society of America Memoirs, v. 197, p. 647-678. 
Tollo, R.P., Aleinikoff, J.N., Borduas, E.A., Dickin, A.P., and McNutt, R.H., 2006, Grenvillian magmatism in the northern Virginia Blue Ridge: Petrologic implications of episodic granitic magma production and the significance of postorogenic A-type charnockite: Precambrian Research, v. 151, p. 224-264.

Watson, E.B., Wark, D.A., and Thomas, J.B., 2006, Crystallization thermometers for zircon and rutile: Earth and Planetary Science Letters, v. 151, p. 413-433.

Watson, E.B., and Harrison, T.M., 2005, Zircon thermometer reveals minimum melting conditions on earliest Earth: Science, v. 308, p. 841-844.

Watson, E.B., and Harrison, T.M., 1983, Zircon saturation revisited: temperature and composition effects in a variety of crustal magma types: Earth and Planetary Science Letters, v. 64, p. 295-304.

Wiedenbeck, M., Alle, P., Corfu, F., Griffin, W.L., Meier, M., Oberli, F., Von Quadt, A., Roddick, J.C., and Spiegel, W., 1995, Three natural zircon standards for U-Th-Pb, Lu-Hf, trace element and REE analyses: Geostandards Newsletter, v. 19, p. 1-23.

Wiedenbeck, M., Hanchar, J.M., Peck, W.H., Sylvester, P., Valley, J., and Whitehouse, M., et al., 2004, Further characterization of the 91500 zircon crystal:

Geostandards and Geoanalytical Research, v. 28, p. 9-39. 


\section{VITA}

\section{Samantha Rae Burk}

\section{Education:}

B.A., Geology/Geochemistry, University of Maine at Farmington, 2008-2012

M.S., Geology, University of Kentucky, 2015-2017 (Expected May 2017)

Professional positions held:

03/17 - Present, Senior Exploration Geologist, Avalon Development Corp., Fairbanks, Alaska

06/15 - 05/17, Graduate Research Assistant, UK, Lexington, Kentucky

10/12 - 05/15, Mine Geologist, CS Mining, Milford, Utah

05/12 - 10/12, Junior Exploration Geologist, Avalon Development Corp., Fairbanks, Alaska

08/09 - 05/12, Undergraduate Research Assistant, UMF, Farmington, Maine

\section{$\underline{\text { Publications: }}$}

Burk, S.R., Gibson, D., and Koteas, C.G., 2012, Field relations, petrography, and geochemistry of mafic dikes, Schoodic Peninsula, coastal Maine: Geological Society of America, Abstracts with Programs, NEGSA, v. 44, no. 2, p. 80.

Burk, S.R., Moecher D.P., and Samson, S.D., 2017, Zircon as a proxy for "taking the temperature” of granites: an example using zircon thermometry applied to Grenvillian mid-crustal magmas in the Blue Ridge Province, Virginia: Geological Society of America, Abstracts with Programs, SEGSA, v. 49, no. 3. 